\title{
Applications for passive sampling of hydrophobic organic contaminants in water - A review
}

Adam C. Taylor ${ }^{\mathrm{a}}$, Gary R. Fones ${ }^{\mathrm{a}^{*}}$, Branislav Vrana ${ }^{\mathrm{b}}$ and Graham A. Mills ${ }^{\mathrm{c}}$

${ }^{a}$ School of Earth and Environmental Sciences, University of Portsmouth, Burnaby Road, Portsmouth, PO1 3QL, UK

${ }^{b}$ Faculty of Science, Research Centre for Toxic Compounds in the Environment (RECETOX), Masaryk University, Kamenice 753/5, Pavilon A29, 62500 Brno, Czech Republic

${ }^{c}$ School of Pharmacy and Biomedical Sciences, University of Portsmouth, White Swan Road, Portsmouth, PO1 2DT, UK

*To whom all correspondence should be addressed

Phone number: +442392842252

e-mail: gary.fones@port.ac.uk 


\title{
Applications for passive sampling of hydrophobic organic contaminants in water - A review
}

\begin{abstract}
We comprehensively review the current state-of-the-art of environmental monitoring for hydrophobic organic contaminants in aqueous matrices using passive sampling devices. Principles of the theory of passive sampling are presented. Strategies for passive sampler design and operation, limitations in performance and data quality-assurance and quality-control are reviewed. Advances in applications of available passive sampling devices are extensively critiqued. Future trends and current challenges facing practitioners and barriers to further adoption of the devices are discussed.
\end{abstract}

\section{Keywords}

Environmental monitoring; Non-polar pollutants; Passive sampling; Sampler applications; Water analysis

\begin{abstract}
Abbreviations
DM, Diffusion membrane; EDA, Effect driven analysis; EDCs, Endocrine disrupting compounds; EQS, Environmental quality standard; EVA, Ethylene vinyl acetate; HLB, Hydrophobic-lipophilic balanced; HOCs, Hydrophobic organic compounds; LDPE, Lowdensity polyethylene; LOQ, Limit of quantification; LSER, Linear solvation energy relationship; MESCO, Membrane-enclosed sorptive coating; MoA, Mode(s) of toxic action; PAHs, Polyaromatic hydrocarbons; PBDEs, Polybrominated diphenylethers; PCB, Polychlorinated biphenyl; PDMS, Polydimethylsiloxane; PES, Polyethersulfone; POP, Persistent organic pollutant; POM, Polyoxymethylene; PMMA, Polymethyl methacrylate; PRCs, Performance reference compounds; PSD, Passive sampling device; QSAR, Quantitative structural activity relationship; SBSE, Stir-bar sorptive extraction; SPM, Suspended particulate matter; SPMD, Semi-permeable membrane device; SPME, Solid-phase microextraction SR, Silicone rubber; TWA, Time-weighted average; WBL, Water boundary layer
\end{abstract}




\section{Introduction}

Hydrophobic organic compounds (HOCs) are present throughout all environmental compartments and may be present in the aquatic environment at trace concentrations (ng L $\mathrm{L}^{-1}$ to pg $\mathrm{L}^{-1}$ ). The risk posed by certain HOCs (e.g. polyaromatic hydrocarbons (PAHs), polybrominated diphenylethers (PBDEs), polychlorinated biphenyls (PCBs)) is well established and these compounds are included in the priority pollutant lists of the EU's Water Framework Directive, EPA's Clean Water Act and the persistent organic pollutant (POP) list of the Stockholm Convention [1-3]. Typically, monitoring programmes for priority pollutants consist of discrete grab (bottle or spot) samples chemically analyzed for compliance with threshold concentrations. Achieving limits of quantification (LOQ) for all priority HOCs can be expensive, requiring collection of large volumes of water and several sample separation, concentration and analytical steps. Additionally, grab samples only provide a 'snapshot' of the aquatic analyte concentration at the moment a sample is taken, which may not accurately reflect the risk posed to human or aquatic organisms [4]. HOC concentrations in the environment vary dynamically, undergoing mass fluxes between environmental compartments in response to long-range transport and regular and episodic pollution, favoring accumulation in sediment and biotic phases. The risk posed by aquatic HOCs to biota may be magnified by microplastic vectors that are now known to be present in waters globally and interact with biota via a number of pathways [5].

Several strategies have been suggested to better assess exposure risk from aquatic HOCs. These strategies include, frequent grab samples or automated sampling, monitoring in biota and sediment. Each of these strategies has advantages and weaknesses. Frequent grab sampling or automated sampling is often unworkable due to restrictions in sampling at remote locations. In addition, unrealistically high volumes of water have to be processed in order to reach sufficiently low method limits of quantification for compliance monitoring. HOC concentrations in whole water do not directly reflect their chemical activity and associated risk to aquatic organisms. Sediment monitoring is less useful when HOC concentrations in overlying waters and sediments are not in equilibrium or the composition of sediments varies over the sampled area. This complicates the comparability of spatial or temporal data. Likewise, chemical monitoring using analysis of aquatic biota is complicated by the large inherent variability in HOC concentrations related to many factors including exposure pathways, organism lipid content, age, gender and trophic position. Moreover, sampler preparation can involve complex analyte extraction and concentration steps. Another approach is the use of 
passive samplers. These devices can provide additional information on freely dissolved aquatic HOCs and provide time-weighted average (TWA) or equilibrium concentrations. Passive sampling overcomes many of the shortcomings of grab, sediment and biota monitoring, caused by variable and poorly defined monitoring matrix composition issues. Materials used in passive sampler construction have constant composition and well-defined diffusion and partition properties. This allows sampling, quantification and the potential to compare HOC concentrations in time, space and across environmental compartments in a reproducible way.

Passive sampling relies on in-situ accumulation of analytes within a receiving phase during an exposure in the sampled medium. Since the last comprehensive review of aquatic passive sampling (all pollutant classes) in 2005 by Vrana et al. [6], knowledge of passive sampling of HOCs has advanced, with $>300$ additional publications since the time of this publication. This review briefly introduces the principles of passive sampling, then presents the new applications of passive sampling for HOCs between 2005-2019.

\section{Principles of passive sampling}

Passive sampling refers to any technique through which analytes present in a bulk phase of the sampled medium are transferred and retained in a receiving phase, where flux of analytes between phases is driven only by differences in chemical potential [7]. If the receiving phase remains in the bulk phase the spontaneous flux of analytes will continue between phases until the difference in chemical potential disappears i.e. thermodynamic equilibrium is reached. The receiving phase may be an adsorbent or absorbent solid, a solvent or a chemical reagent, which can be lose or stabilized on or in a supporting matrix. Typically, the receiving phase of PSDs for HOCs is either a hydrophobic solvent or an absorbent non-polar elastomer [8]. Adsorbent receiving phases are used less frequently [9].

Partitioning of HOCs between phases typically follows first order kinetics. This can be described by a one-compartment mathematical model, where the analyte concentration in the receiving phase $C_{s}$ at a known exposure time $(t)$, is proportional to the analyte concentration in the bulk phase $C_{w}$, and the uptake $k_{1}$, and dissipation $k_{2}$ constants. Accumulation of analyte in the receiving phase occurs in kinetic followed by equilibrium regimes. The first order model can be described by equation (1): 


$$
C_{s}(t)=C_{w} \frac{k_{1}}{k_{2}}\left(1-e^{-k_{2} t}\right)
$$

PSDs can be operated in either the kinetic or equilibrium regime. Different devices exposed at the same location for an equal time, may not produce comparable results for all HOCs. Before exposure, it is important the design and operation of the PSDs are considered alongside the characteristics of HOCs present in sampled waters. This will ensure the design of the monitoring programme provides the most appropriate results to answer the experimental question [10].

\subsection{Equilibrium passive sampling}

Equilibrium PSDs are exposed for sufficient time for the concentration of analyte in receiving and bulk phases to reach thermodynamic equilibrium. In a theoretical system where the analyte concentration in the bulk phase is constant and is not depleted by accumulation in the receiving phase, once equilibrium is reached the concentration of analyte in the receiving phase will not change and the aquatic concentration of HOCs can be derived using receiving phase-water partition coefficients $\left(K_{s w}\right)$ [11-15]. The time taken to attain this theoretical equilibrium is referred to here as $t_{e q}$. Environmental concentrations of HOCs are dynamic. The suitability of PSDs operated in the equilibrium regime will depend on the magnitude and arbitrariness of analyte concentration variability in the bulk phase and the response time of the PSD. This must be shorter than said variations in concentration. Environmentally significant concentrations of certain HOCs in aqueous media are often trace (ng L $\mathrm{L}^{-1}$ to $\left.\mathrm{pg} \mathrm{L}^{-1}\right)$ and relatively stable and in these circumstances, PSDs operating in the equilibrium regime are appropriate [16]. When PSDs are operated in the equilibrium regime equation (1) can be altered to equation (2):

$$
C_{S}=C_{w} \frac{k_{1}}{k_{2}}=C_{w} K_{S W}
$$

\subsection{Kinetic passive samplers}

Kinetic passive samplers are designed and operated so that accumulation of target HOCs is time integrative and responsive to concentration changes in the sampled water (kinetic regime). In the kinetic regime, initial accumulation in the receiving phase is linear (if $C_{w}$ is constant), as the HOC dissipation rate $\left(C_{s} k_{2}\right)$ from the sampler is negligible compared to the uptake rate $\left(C_{w}\right.$ 
$k_{1}$ ) [8]. Increases in analyte concentration in the receiving phase and the dissipation rate are proportional. Accumulation of analyte is integrative until the theoretical time at which the magnitude of the dissipation rate is no longer negligible in relation to the uptake rate, referred to here as $t_{\text {lin }}$. After exposure time $t_{\text {lin }}$, accumulation is curvilinear approaching an asymptote at thermodynamic equilibrium $\left(C_{s} k_{2}=C_{w} k_{l}\right)$ at exposure time $t_{e q}$. The kinetic regime ends at $t_{e q}$ (equilibrium). Kinetic PSDs are operated between $t_{0}$ and $t_{l i n}$ in the linear uptake stage of the kinetic regime. During this stage the uptake rate is linearly proportional to the concentration in the bulk phase and sampling is time-integrative [8]. Here equation (1) can be reduced to equation (3):

$$
C_{s}(t)=C_{w} k_{1} t
$$

Kinetic PSDs are used to measure TWA concentrations of analytes in the aqueous phase. In this case equation (3) can be rearranged in order make the analyte mass in the receiving phase $\left(M_{s}\right)$ at the end of the exposure $(t)$ the subject:

$$
M_{s}(t)=C_{w} R_{s} t
$$

Here $R_{S}$ represents the sampling rate (unit volume of water sampled per unit time). If the analyte mass in the receiving phase is measured and the sampling rate is known it is possible to calculate the average analyte concentration $\left(C_{T W A}\right)$ over exposure time $(t)$ by rearranging equation (4):

$$
C_{T W A}=\frac{M_{S}}{R_{S} t}
$$

In order to determine TWA analyte concentrations in the bulk phase the $R_{S}$ is required. The sampling rate is a product of the overall mass transfer coefficient and sampler surface area $k_{\mathrm{o}} A$ [8]. In case of water boundary layer controlled HOC uptake, the mass transfer coefficient $k_{\mathrm{o}}$ is affected by water flow velocity and turbulence. In such cases site specific sampling rates can be derived from the release rate of performance reference compounds (PRCs) covering the hydrophobicity range of analyzed compounds $[17,18]$. Models are available that relate water boundary layer controlled sampling rates with molar mass [19]. For compounds slowly diffusing in the membrane or receiving phase material, diffusion in those media may be rate- 
limiting. Knowledge of diffusion coefficients of analyzed HOC in those media is therefore important for assessment of the main barrier controlling the uptake [20].

\subsection{Passive sampler design}

An ideal passive sampler design is inexpensive with a simple construction, easy to prepare, deploy, retrieve and analyze, and has selectivity and sensitivity for a wide range of analytes [21]. In practice, passive sampler design is optimized according to several objectives and no device is suitable for all applications. Devices are either single or dual phase. Single phase polymer PSDs form the simplest designs. Here polymer formulation and surface area to volume ratios can be selected to alter sampler performance [22]. Polymers such as polyoxymethylene (POM) are favored for sampling in the equilibrium regime because of their high resistance to mass transfer in the polymer (low polymer diffusion coefficient $\left(D_{p}\right)$ ) and low $K_{s w}$. This compares to the use of low-density polyethylene (LDPE) or silicone rubber (SR), which results in a faster (apparent) equilibrium in POM (surface layer only). Migration of HOCs within the POM polymer cross-section can bias this apparent equilibrium with increasing storage time of retrieved samplers $[23,24]$. Dual phase passive samplers such as the Chemcatcher ${ }^{\circledR}$ contain a $^{2}$ receiving phase and a diffusion membrane (DM). The DM effectively extends the kinetic regime by slowing diffusion between the aqueous and receiving phases [25]. In the semipermeable membrane device (SPMD), the DM retains the liquid receiving phase (triolein). Polymer-water partition coefficients increase with the hydrophobicity of HOCs. For very hydrophobic compounds $\left(\log K_{o w}<5.5\right)$ equilibrium cannot be attained even with deployment times in excess of several months [26]. Where equilibrium is unlikely within the exposure time, the extent of equilibration must be quantified [8]. Passive sampler design considerations differ when quantitative TWA concentrations (kinetic regime) are desired. Ideally these designs should have a $D_{p}$ that does not limit uptake, demonstrate isotropic exchange of PRCs and have a sufficiently high $K_{S w}$ and $R_{S}$ so that $t_{\text {lin }}$ is longer than the exposure time. $M_{S}$ (after extraction) needs to be > LOQ of the analytical method. The design of deployment apparatus may also influence sampler performance. Novel PSDs for HOCs in aquatic matrices continue to be developed $[27,28]$. However, as researchers and legislators try to incorporate passive sampling into frameworks for regulatory monitoring, existing designs for which performance, applications and inter-comparability of data are well established are likely to be preferred. 


\section{$2.4 \quad$ Calibration of passive samplers}

Calibration of PSDs is necessary in order to relate $C_{s}$ to $C_{w}$ by determining $R_{s}$ and $K_{\mathrm{sw}}$, as required for the calculation according to equations 1-5. Calibration of PSDs for HOCs in aqueous matrices may be undertaken in-situ by measuring isotropic exchange of PRCs. Less accurate alternate approaches may involve calibration prior to exposure in simulated conditions, or the formation of empirical [19], mechanistic [29], linear solvation energy relationship (LSER) [30] or quantitative structural activity relationship (QSAR) [31] models. The development of models enables the calculation of the relationship between molecular structural features and substance specific mass transfer coefficients and partition coefficients. The influence of exposure specific uptake limiting factors mean that theoretical uptake kinetics derived from first principles or observations disagree with those realized in practice [6]. As such, calibration approaches which seek to capture analyte and exposure specific variation in uptake are generally favored [21]. Calibration of PSDs requires prior knowledge of the environmental conditions during deployment in order to accurately replicate them in the laboratory. Experiments must be carefully designed to account for depletion of HOCs in the aqueous phase due to transfer to the receiving phase and sorption to surfaces in the calibration system [19]. Laboratory exposures usually consist of either a flow-through system containing freshly spiked water or a closed system where the spiked water is replenished at set intervals. Despite differences in experimental design, variation in derived $R_{s}$ and $K_{s w}$ between studies uncovered no method bias. Practitioners have identified and actioned the responses necessary to reduce this variation as part of the wider coalescence towards improving data quality assurance [32] (see Section 5). Perhaps the best approach is through use of PRCs, which has now been extensively demonstrated for various PSDs [18, 33]. PRCs are stable isotope labelled compounds absent in the sampled phase and added to the receiving phase prior to exposure. The mass of these compounds remaining in the PSD can be used to correct for uptake ratelimiting factors and infer the $R_{S}$ and the extent of equilibration [18]. Often PRCs are isotopically labelled analogues of target HOCs. However, PRCs can be other suitable labelled analogues or HOCs (not present at the exposure site) $[26,34,35]$. The dissipation rate is dependent on analyte $K_{s w}$, less hydrophobic analytes may dissipate entirely, whilst compounds with high $K_{s w}$ values may not dissipate sufficiently to calculate $R_{s}$ values during a deployment [18]. Booij and Smedes [18] developed the now consensus method (unweighted non-linear least-square regression) to extrapolate the data obtained from the use of PRCs to estimate $R_{s}$ and the extent of equilibration. This improved on previous methods by reducing the analytical bias found by the use of individual PRCs. 


\subsection{Uptake rate-limiting environmental factors}

Rate-limiting environmental factors affecting the uptake of HOCs to PSDs can be divided into those which influence mass transfer resistance by the presence of an intermediary phase at the sampler-water boundary (e.g. biofouling or water boundary layer (WBL)) and the influence the physiochemical condition of the aqueous phase (e.g. temperature) may have on mass transfer [19]. It is the exposure and compound specific effects of these factors that necessitate the calibration of PSDs [36]. For example, an increase in temperature causes an increase in $R_{S}$ [37]. For very hydrophobic HOCs, rate-limiting factors at the sampler-water boundary have the greatest influence on $R_{s}$ and for HOCs with a low $K_{s w}$, temperature is likely to be rate-limiting [8].

\subsection{Fouling}

Natural waters contain a variety of microbial flora and fauna able to colonize virgin surfaces, including PSDs [38]. Once colonized a biofilm may form, further incorporating higher organisms (e.g. annelids and crustaceans), colloids and other deposited particles from the water column as it develops. Formation and community structure of fouling films is dependent on the composition of sampled waters. Factors include number of microorganisms with potential to form biofilms and the concurrent presence and abundance of substrates for cell metabolism [39]. Other factors include the ease of colonization of the surface of the PSD for cell/particle attachment, competition and predation between members of the biofilm and the presence of any added biocidal compounds within the PSD [39, 40]. Accordingly, the thickness and composition of fouling films are never uniform. The formation of biofilms between aqueous and receiving phases may increase resistance to mass transfer of HOCs. It is therefore necessary to quantify (with PRCs) any rate-limiting effect attributable to fouling during exposures [4143]. A review of biofilm formation on aquatic microplastics introduces the possibility that certain HOCs may be metabolized within biofilms [39]. The potential for metabolism of HOCs may differ between aqueous media [44]. Theoretically, such metabolism could obfuscate PRC correction by suppressing HOC accumulation in the receiving phase or altering the dissipation rate of biodegradable PRCs such as DDT [45] or certain PAHs [46]. For instance, if the rate of metabolism creates a functionally greater difference in chemical potential at the biofilmsampler boundary than generated through PRC transport/elimination through biofilm and WBL phases alone, the dissipation rate would increase. Whilst neither effect has been confirmed to date, Allan and Jenssen [47] observed anisotropic exchange favoring dissipation of PRCs in heavily fouled PSDs and decreased $M_{s}$ up to a factor of 27 for certain PAHs, when compared 
to co-deployed unfouled devices. This was attributed to the high refractory carbon content of suspended particulate matter (SPM), thought to predominate in the fouling film. This favoured mass transfer from the sampler to the fouling layer and was not thought to result from bacterial metabolism. It should be emphasized that the use of PRCs to correct for the influence of fouling has been demonstrated [40], and remains appropriate. However, in the rare cases where extreme fouling causes anisotropic exchange, the PRC dissipation profile may not indicate this bias [47]. Sampling of material contained on heavily fouled PSDs with SPME (coated with same polymer as the fouled PSD) for the presence of PRCs and HOCs could indicate whether fouling has caused a bias. Determining whether metabolism of sampled HOCs has taken place in the biofilm may be difficult. Readmittance of isotope labelled transformation products of PRCs such as DDD (formed by microbial metabolism of DDT in sedimented material) to LDPE PSDs, has been demonstrated by Tcaciuc et al. [45]. Comparison of fouled and unfouled PSD extracts in toxicological analysis may help identify the metabolism of sampled HOCs through the presence/absence of triggered toxicological endpoints, without prior knowledge or need to identify HOCs.

\subsection{Coupling passive sampling to toxicological and qualitative chemical analysis}

To determine the risk posed to biota by pollutant mixtures, tools to reduce the complexity of the sampled matrix and to identify adverse effects are required (effect assessment) [48]. Targeted analysis only focuses on regulated HOCs or those with known or suspected presence/toxicity. This approach neglects the majority of the potentially thousands of chemicals present [49]. Effect assessment workflows vary and may consist of separation, enrichment, dilution, biotesting, analyte fractionation and confirmation steps. Workflow design must be carefully formulated to avoid discrimination of compounds and ideally biotesting, analyte confirmation as well as fractionation or dilution will be iterative and tiered, such as in effect driven analysis (EDA) [49]. In EDA the first tier will identify the mode(s) of toxic action (MoA) with each iteration/tier further resolving the contribution of HOCs exerting the same MoA in mixtures. Biotesting identifies MoA through a range of bioassays. These are in vitro or in vivo bioanalytical tests eliciting an observable biological response when a toxicological endpoint is triggered [50]. Fractionation of HOCs is generally achieved through chromatographic separation [51]. Analyte confirmation is variously target, suspect or unknown, with primary, ancillary or no quantitation. 
Passive sampling in effect assessment of HOCs is nascent [52-60], likewise qualitative screening of PSD extracts is developing [53, 61-63]. A review by Brack et al. [49] highlighted the potential for analysis of extracts from PSDs operated in the equilibrium regime as 'model organisms' mirroring the bioaccumulation profile of HOCs. Limitations presented, included long equilibrium times in water and the limited extract available for analysis. Restriction of kinetic PSDs to qualitative assessments was recommended due to incongruent HOC profiles among receiving, aqueous and biotic phases. Variability in data obtained from passive sampling has been demonstrated to result from differences in the $K_{s w}$ values used [18], and interlaboratory inconsistency in analysis and calculation methods [64]. Considering this variability, incorporation of passive sampling into effect assessment workflows should be deliberate. This is to ensure no bias is introduced and if toxicological and/or qualitative chemical analysis of PSD extracts is undertaken, limitations and uncertainty should be determined and reported. Passive dosing with PSDs has been suggested in place of spiking with an extract (whole or fraction), because it eliminates the effect of extraction solvents on the biological system. However, the throughput of the system may be reduced [49]. Claessens et al. [56] found passive sampling coupled to passive dosing proved a complimentary tool in a toxicological study and suggested the inclusion of several PSD designs with a broad selectivity of HOCs, to make any characterization as representative possible.

\section{Types of passive sampling device}

PSDs for HOCs in aquatic matrices can be broadly split between single-phase polymeric PSDs (e.g. LDPE, polyethersulphone (PES), POM, SPME, SR) and dual-phase devices such as the SPMD and Chemcatcher ${ }^{\circledR}$. Among PSDs for HOCs the extant literature on the SPMD remains the most extensive. However, the application of single phase polymeric PSDs has expanded since the first comprehensive study into the application of LDPE by Adams et al. [65] and the establishment of criteria for polymer selection by Rusina et al. [66]. Among single-phase polymeric PSDs the most publications have been on LDPE and SR with a variety of studies on sampler performance and numerous field applications. Factors influencing the increased popularity of single-phase polymeric PSDs include their simple construction and low cost when compared to the SPMD and Chemcatcher ${ }^{\circledR}$. Since the last review by Vrana et al. [6] other PSDs such as the Chemcatcher ${ }^{\circledR}$ and solid-phase microextraction (SPME) have seen a number of publications on sampler performance and calibration with a comparatively limited number on other applications. Whilst the use of several other PSDs has fallen out of favor, notably the membrane enclosed sorptive coating (MESCO), the ceramic dosimeter and solvent-filled 
dialysis membranes. It is likely that in the future single-phase polymeric PSDs will remain popular and SPME will be increasingly adopted as has been seen in other areas of sample separation and environmental monitoring. Fig. 1 shows a range of PSDs used for HOCs. Figures of merit of the available hydrophobic passive samplers are summarized in Table 1.

\section{[Figure 1 near here]}

\section{[Table 1 near here]}

\subsection{Semi-permeable membrane devices}

SPMDs were first described in 1990 by Huckins et al. [90]. SPMDs consist of a sealed lay flat tube of thin walled non-porous LDPE containing a thin film of liquid receiving phase. Triolein is conventionally used as receiving phase, as it is the major storage lipid found in most organisms and it has low permeability through LDPE membranes. Other advantages of triolein include the similarity in magnitude, and good correlation of, triolein-water and $n$-octanol-water partition coefficients, and low triolein-LDPE interfacial tension. Non-porous LDPE was selected as the diffusive barrier because; the structure of its polymer chains permit dissolution and uptake of the bioavailable fraction of dissolved and vapor phase HOCs, it is stable in the presence of organic solvents, it is relatively resistant to physical damage and it is widely available [91]. The SPMD was intended to be biomimetic of HOC accumulation in biota. This was not demonstrated, however, as true equilibrium within a PSD is never attained for all HOCs present [26] and because of variability of accumulation in biota [92]. Subsequently, the LDPE was found to contribute significantly to uptake capacity [93]. The major milestone in the development of the SPMD was the development of PRCs [17, 93]. This demonstrated that the rate-limiting step in the uptake of very hydrophobic HOCs into the SPMD occurred at the water boundary layer. In addition, uptake was isotropic, allowing site specific uptake rates in response to differing environmental factors to be accurately interpreted though differential dissipation of PRCs [94]. This approach has since been applied to other aquatic passive samplers. Since 2005 there have been $>150$ publications on the SPMD on a variety of applications, more than any other passive sampler of HOCs. Recently, updated experimental $K_{s p m d / w}$ values for a range of HOCs were published [11], which show a linear $K_{s p m d / w}-K_{o w}$ relationship in contrast to the parabolic relationship suggested in the USGS "SPMD Water Concentrations Calculator" [68]. Smedes [11] recommended that in combination with revised $K_{\text {spmd/w }}$, a different model approach 
should be used for obtaining accurate aqueous concentrations from passive sampling measured with SPMD.

\subsection{Silicone rubber devices}

SR devices derive from a number of sorptive extraction techniques (e.g. stir-bar sorptive extraction (SBSE), SPME, rods, tubes and sheets) based on silicone polymers [95]. The popularity of this sampler grew with confirmation of the suitability of SR polymers for sampling, solvent extraction and analysis through thermal desorption coupled to cold injection and GC/MS analysis [66]. HOCs have fast diffusion coefficients in this material [20]. Polymerwater partition coefficients and models relating sampling rates to compound properties $[13,19$, $22,75]$, field testing [23] and the suitability and quality of PRCs [18] have all been evaluated.

Diffusion coefficients within SR are typically 2-2.5 orders of magnitude greater than in LDPE [20]. This fact elevated the use of SR in passive sampling of HOCs ahead of a range of other polymers. SR PSDs typically consist of strips or sheets of silicone elastomers, such as polydimethylsiloxane (PDMS), however, samplers based on rods or SBSE are also used [9699]. Cleaning and preparation is required prior to deployment to remove artefacts (e.g. oligomers) within the SR polymers, that, if not carefully removed, may cause instrumental interference during analysis [71]. Since 2005, there have been $>80$ publication on SR PSDs of HOCs in aquatic matrices. Their adoption by more practitioners is being facilitated through an annual proficiency testing (QUASIMEME) [100].

\subsection{Low-density polyethylene devices}

The development of LDPE PSDs began when Booij et al. [93] suggested using the LDPE membrane from a SPMD as a single phase device, i.e. without internal triolein. This was followed by initial field studies by Müller at al. [78]. However, it was not until more extensive field performance studies were undertaken in 2007 [65] that the use of LDPE gathered momentum. Since $2005>80$ publications have utilized LDPE PSDs for measuring HOCs in aqueous matrices. A number of these studies combined passive sampling of aqueous phases with other phases such as the atmosphere to determine mass fluxes of HOCs between environmental compartments. LDPE comprises long linear polymer chains with short and long branches at approximate intervals of 25 and 50 monomer units respectively. This results in a crystallinity of 35-55\% [101]. LDPE diffusion coefficients are lower than SR and higher than POM $[20,66]$. LDPE polymers contain less potential artefacts than SR and are more widely 
available at lower cost. Absorption of HOCs within LDPE follows the same process as that in other single phase polymeric devices (e.g. SR), with uptake proportional to LDPE-water partition coefficients [101].

\subsection{Chemcatcher ${ }^{\circledR}$}

The Chemcatcher ${ }^{\circledR}$ PSD was developed by Kingston et al. [102]. Unlike other PSDs the Chemcatcher $^{\circledR}$ consists of a reusable three-part PTFE body (base plate, retaining ring and transport lid) which houses a commercially available $47 \mathrm{~mm}$ SPE disk Empore $^{\mathrm{TM}} /$ AttractSPE $^{\mathrm{TM}} /$ Atlantic $^{\mathrm{TM}}$ ) receiving phase overlain with a DM. The choice of receiving phase and DM is made on the basis of which have the required selectivity and sensitivity for the analyte(s) being monitored. Since the original development of the Chemcatcher $^{\circledR}$, the design of the device has undergone several iterations. The receiving phase in earlier designs sat within a recess. More recent designs have removed this recess to increase uptake rates for HOCs (and other analytes) by reducing the length of the effective diffusional path between bulk and receiving phases [103]. Since 2005 improvements have been made to sampler performance. These included the combination of a $\mathrm{C}_{18}$ receiving phase and LDPE DM to monitor HOCs, and the addition of $n$-octanol to the interstitial space between receiving phase and DM to reduce internal resistance to mass transfer within the device [80]. PRCs to determine the influence of rate-limiting interactions at the membrane-water boundary $[36,82]$ have been used as well as comparative field trials alongside other PSDs [69]. Despite this, the application of the non-polar Chemcatcher ${ }^{\circledR}$ PSD since 2005 has been modest at $>25$ publications. One of the limitations is its small surface area $\left(17 \mathrm{~cm}^{2}\right)$. Since the sampler body has a set dimension, upscaling of the device to larger surface area is not possible. In order to reach required limits of quantification (analytes in the range of $\mathrm{pg} \mathrm{L}^{-1}$ ) multiple devices can be exposed in parallel and sampler extracts combined into a pool. Such an approach is more costly than the use of SR or LDPE.

\subsection{Solid-phase microextraction}

SPME was developed by Pawliszyn and Arthur [104] as a sensitive, solvent free, economical and easily automatable sample preparation technique. The distinction between on-site sampling and passive sampling with SPME is not always clear. This review only considers applications of SPME where the aqueous matrix is sampled directly (i.e. without, the addition of internal standards or buffers, filtering or agitation of the sampled matrix). Reviews of on-site sampling $[105,106]$, analysis of water [107], geometry and coatings [108], and future directions [109, 
110] provide an introduction to the diversity of SPME designs and applications. SPME PSDs are formed typically of a narrow glass fiber with a thin polymeric (liquid or solid) coating. Uptake capacity is determined by the polymer-water partition coefficient and fiber thickness (related to polymer mass applied on the fiber). Due to the limited polymer mass only a very small mass of analyte is sampled. Typically, extraction is non-depletive of the analyte in the sampled medium and equilibrium can be achieved in a relatively short time (within hours). If it is desirable to extend integration times (for instance when measuring TWA concentrations of HOCs), polymers with a higher capacity or thicker polymer coating can be selected. Another strategy to extend the integrative sampling period is to have the SPME fiber recessed within in a sheath (such as a needle). This strategy has the added advantage of protecting the fiber during deployments and if the sheath has a narrow enough opening, entry of analytes into the diffusion channel within the sheath will be independent of water flow. Another problem encountered with SPME is the interference of macromolecules when sampling complex matrices (such as contaminated water). This can be overcome with the addition of a selective membrane to exclude molecules based on size. This has the further advantage of extending the integrative period and provides the opportunity to fill the diffusion channel beneath the membrane with a liquid with a higher transfer coefficient than the sampled medium thereby decreasing transfer along the diffusional channel further. When adopting these approaches, it is important efforts to extend the integration time do not sacrifice measurement sensitivity, and that field handling and deployment is practicable [8]. Since 2005 there have been $>25$ publications on SPME PSDs of HOCs. Most of these have investigated the performance of the device in a range of field applications including the use of PRCs [111] [112]. In future, the application of SPME PSDs is likely to increase, particularly if devices for field application can be made simpler to use (by non-experts), more reliable and easily coupled to automated analytical methods. These advances have already been seen in the application of SPME in clinical, food and forensic sectors [113].

\subsection{Other polymeric devices}

Non-polar polymers have been shown to be effective single phase PSDs for HOCs, with most research since 2005 investigating LDPE and SR . Other polymers have been investigated (mainly for niche applications) and include polyurethane (PU), ethylene vinyl acetate (EVA), polymethyl methacrylate (PMMA), nylon, PES and mixed polymers (e.g. PDMS/hydrophobiclipophilic balanced (HLB) sorbents). However, of the $>30$ publications since 2005 most publications have investigated POM. POM PSDs are used when it is desirable to deploy the 
same polymer in sediments and overlying waters [114]. POM PSDs are made typically of 0.055 $\mathrm{mm}$ thick strips (various lengths), which are deployed as an equilibrium PSD over exposures of at least 4 weeks. $R_{\mathrm{S}}$ in POM are low and uptake is membrane controlled, as the resistance to mass transfer in the polymer is greater than in the WBL. True equilibrium is not reached in POM PSDs during typical exposures, owing to low $D_{p}$, instead an apparent equilibrium in the surface layer occurs [66]. In future, usage of POM is likely to be restricted due to difficulty in interpreting data due to its functionally biphasic uptake kinetics. Mono-phasic mixed polymers are likely to become more popular, as the multiple affinity for analytes extends the range of hydrophobicity over which devices can operate $[28,115]$.

\section{Applications of passive sampling}

All peer reviewed publications where passive sampling of HOCs in aqueous matrices was investigated between the publication of the critical review by Vrana et al. [6] in 2005 and 2019 are reviewed. Fig. 2 presents number of publications by year for the main types of PSDs. An overview of each application is provided. Delineation of the extant literature identified the following main applications:

i) Monitoring of process efficacy

ii) Monitoring discharges and dispersal of pollutants

iii) Chemical speciation, distribution and degradation

iv) Monitoring spatial and temporal trends

v) Toxicity and toxicological monitoring

vi) Calibration and sampler performance

vii) Monitoring alongside biota

viii) Comparison of passive sampling devices

In this review, classification of the application was based on the main subject of a given study. Tables 2-7 review applications differentiated by the PSD together with the HOCs monitored and the matrix sampled. A short description of each application is given, and citation(s) provided. Table 8 presents research and reviews of studies comparing the performance of different passive sampling devices or methods.

\section{[Figure 2 near here]}




\subsection{Monitoring of process efficacy}

PSDs have been used to monitor various processes designed to reduce HOC concentrations in water (17 applications). This included several unusual processes where conventional tools (e.g. grab or spot sampling) may not have adequately captured said reduction. Namely, inference of sorption of terpenes to carbonaceous geosorbents $[116,117]$, sediment remediation strategies [118-120], and a bioretention cell for stormwater treatment [121]. Passive sampling coupled to target chemical analysis and toxicological analysis was used to investigate operational multistage treatment process for petroleum wastewater and drinking water [122-126]. Most studies investigated municipal wastewater treatment. Here, passive sampling was used to monitor concentrations of HOCs before and after primary, secondary and advanced treatment processes, including alongside biota, active sampling and numerical simulations [127-133]. These studies were all united by analysis of a predefined list of target analytes and/or MoA. One study investigated a potable wastewater reuse scheme incorporating physical, chemical and biological treatment processes [53]. Here, several versions of the Chemcatcher ${ }^{\circledR}$ with selectivity for analytes ranging over a broad hydrophobicity were used to screen against $>1000$ organic chemicals and to assign toxicity through several bioassays. An effect-based screening approach is particularly suited to wastewater treatment processes where input water composition and the performance of biological processes (driven by unique microbial communities) are temporally and spatial diverse [134]. Legislation such as the EU Urban Wastewater Treatment Directive recognizes this diversity through site specific discharge permits, stipulating compliance with threshold values for oxygen demand, suspended solids and nutrients [135]. This approach neglects emerging pollutants in wastewater such as the HOC nonylphenol [136]. A review of emerging pollutants in wastewater by Petrie et al. [134] highlights the restrictions posed by grab sampling (snap shot only) and flow proportional composite sampling (logistics and chemical stability) and proposes passive sampling as a possible alternative monitoring method.

\subsection{Monitoring of discharges and dispersal of pollutants}

Waters receiving discharges containing HOCs have been monitored widely with PSDs (29 applications). Many of these studies have monitored the dispersal of produced water from offshore oil and gas installations, including alongside biota [137-143]. Other discharges monitored, resulted from paper mills (dioxins and endocrine disrupting compounds (EDCs)) [144, 145], wastewater treatment (triclocarban, synthetic musk's, PCBs and pesticides) [146154], smelters (dioxins) [114] and human settlements in Antarctica (PAHs) [155]. Dispersal of 
pollutants resulting from activities in the water column included, salvage operations (PAHs) [156], oil spills (PAHs) [157] and pisciculture (PCBs and pesticides) [158, 159]. Dispersal through atmospheric deposition was also monitored at varying distances from oil sands operations (PAHs) [160]. Passive sampling was shown to be a suitable tool for monitoring pollutant discharges and their subsequent dispersal. Data obtained through passive sampling was found to be more representative than grab sampling, particularly where discharges were discontinuous, the composition was variable and/or the dynamics of dispersal (e.g. river hydrology) and distance from source complicated timing of grab sampling.

\subsection{Chemical speciation, distribution and degradation}

Due to the limitations of grab samples coupled to remote analysis, PSDs are often favored for this application (28 applications). PSDs have been used to investigate the distribution of HOCs between particulate, dissolved and colloidal phases in rivers [161, 162]. PSDs have been deployed at depth gradients in the water column to elucidate the vertical distribution of HOCs, including the effects of photodegradation of HOCs within SPMDs [163-170]. Remobilization of HOCs from sediment to aqueous phases has been tested in field and laboratory exposures [171-173]. The influence of matrix complexity (organic matter) on dissolved HOC concentrations was investigated in lab exposures [174]. PSDs were deployed in coastal waters and used to predict the concentrations of HOCs in other environmental compartments through equilibrium models $[175,176]$. PSDs have been exposed in sediments, pore waters, waters and the overlying atmosphere (gaseous and aerosol) to determine activity gradients across environmental compartments [177-185]. In future, passive sampling is likely to be applied to other emerging questions concerning the distribution of chemicals between environmental compartments. For example, PSDs deployed in the equilibrium regime can be used to understand the partitioning and half-lives of HOCs absorbed to microplastics [186].

\subsection{Monitoring spatial and temporal trends}

Spatial and temporal trends in HOC concentrations have been investigated in many different aquatic matrices (59 applications). Temporal investigations have occurred over time periods (several years) as prolonged as the impoundment of the Three Gorges Dam (China) [187-189]. Other studies have investigated the ability of methods such as grab sampling and passive sampling to integrate sporadic fluxes in HOC concentrations within river catchments [70, 190207]. Monitoring of spatial trends have occurred at distinct locations and different levels of resolution, ranging from a raft expedition across an ocean [208] to the distribution of HOCs in 
surface waters at different altitudes in a mountain range [209]. PSDs deployed in the kinetic regime are typically favored for applications investigating temporal variation, due to their ability to integrate variations in concentration. Equilibrium and kinetic samplers have both been applied in a number of spatial investigations. Current regulatory monitoring programs (surveillance mode), which routinely monitor spatial and temporal trends in concentrations of priority pollutants currently exclude passive sampling. However, the Environmental Quality Standards Directive 2013/39/EU [210] recognizes the potential for future application of passive sampling and promotes method development. Efforts to demonstrate the utility of passive sampling are underway, such as the creation of a strategic global network of passive sampling stations (AQUA-GAPs project) [72, 211]. As methods become more robust and are adopted by more laboratories, the justification for the establishment of environmental quality standard (EQS) for freely dissolved concentrations (as measured by PSDs) in compliance monitoring will increase (see section 5) [10].

\subsection{Toxicity and toxicological monitoring}

PSDs have been shown to be an adaptable tool for assessing the toxicity of HOCs in aquatic matrices (50 applications). A great diversity in study design is observed with applications ranging from the use of SPME as a biomimetic extraction procedure applied to simulated oil spills [212, 213] to using Chemcatcher ${ }^{\circledR}$ to monitor the exometabolome of fish under different husbandry conditions [214]. Studies have also used sampler extracts in effect-based assessment, such as EDA with iterative fractionation coupled to bioassays (e.g. microtox, AhR agonist, Vtox) to determine HOC toxicity. Recognition of the need to quantify the toxicity of HOC mixtures is increasing. The working group on the Water Framework Directive (Chemicals) have proposed the adoption of holistic monitoring incorporating analytical and effect assessment and the establishment of EQS for groups of substances exerting the same MoA [215]. The EU SOLUTIONS project investigated the suitability of passive sampling and spot sampling to toxicologically profile a European river and found each method to be complimentary [54]. Standardization and expanded use of passive sampling in toxicological monitoring is likely in the future [216].

\subsection{Calibration and sampler performance}

Before a PSD can be used in environmental monitoring it is necessary to qualify sampler performance with numerous laboratory and field studies have been undertaken to this end (98 applications). The reliability of data obtained from passive sampling is contingent on accurate 
values for analyte specific coefficients describing kinetics and partitioning in bulk and receiving phases. Equilibrium polymer-water partition coefficients have been determined through PSD exposures in reference media and co-solvent solutions [14, 75, 217]. Polymer diffusion coefficients have been investigated though film stacking experiments and exposures that overcome the rate-limiting effect of the WBL [12, 20, 218-220]. In addition, several theoretical models have been developed which attempt to predict these values (both $K_{s w}$ and $D_{p}$ ) from first principles [30, 221-223]. Building on these fundamentals, other studies investigated the influence of polymer selection [66], formulation [95], thickness [89] and PSD geometry [103] on performance. Rate-limiting environmental factors such as temperature [224, 225], fouling $[40,42,43,47,202]$ and flow velocity $[224,226]$ and the suitability and data quality of PRC correction [18] have been extensively reported. Several inter-laboratory studies have demonstrated between laboratory variability greater than within laboratory variation, with still greater degrees of variation at lower concentrations. This has been attributed to analytical and calculation errors $[64,227]$. The uncertainty of results obtained from passive sampling are approximately a factor of two [69], and efforts to improve data quality assurance and control are ongoing.

\subsection{Monitoring alongside biota}

PSDs have been deployed alongside trophically diverse biota species to assess bioaccumulation and biomagnification of HOCs (29 applications), including the development of models [29, 228-230]. Studied biota included, bivalves, fish, crustaceans, insects, annelids and seagrass. Captive and resident biota have been used with approaches ranging from analysis of caged mussel tissues and co-deployed PSDs [137-140, 142], to PSDs deployed on the surface of fish [231]. Extrapolation of concentrations in biotic phases is best described for biota at lower trophic levels with increasing uncertainty at higher positions. Analysis of PSD extracts is considerably simpler than biota tissues or lipids, likewise passive sampling eliminates the need to collect or introduce representative biota. Biota monitoring is permissible in the Water Framework Directive if spot sampling cannot achieve the required sensitivity and EQS biota $_{\text {has }}$ replaced EQS ${ }_{\text {water }}$ for several priority substances [210]. Given the inherent limitations of biota monitoring, passive sampling may represent an improvement in method reliability [232]. Updated guidance acknowledges this and permits the development of methods using passive sampling as part of a tiered approach, to prioritize biota monitoring at subsequent tiers [233] e.g. the tiered sampling approach proposed by Miège et al. [32]. 
[Table 2 near here]

[Table 3 near here]

[Table 4 near here]

[Table 5 near here]

[Table 6 near here]

[Table 7 near here]

[Table 8 near here]

\section{Incorporation of passive sampling into regulatory monitoring of HOCs}

Improvement and standardization of passive sampling methodologies to enable their inclusion in regulatory monitoring has been a goal of practitioners for some time. This goal was advanced in 2011 with the publication of ISO 5667-23:2011 [380]. A 2015 workshop involving representatives from academia, industry and regulatory agencies, discussed this theme and agreed the next steps towards inclusion in regulatory monitoring [32]. These seek to ensure quality assurance and control (i-vi) and demonstrate method applicability (vii-ix):

i) Uptake should be absorption based with sufficiently high $K_{p w}$ and $D_{p}$, to allow for good analyte accumulation and WBL controlled uptake.

ii) Development of harmonized guidelines for, measurement of $K_{p w}$ and $D_{p}$, PRC correction and calculation of $C_{w}$ with validated models.

iii) Provision of certified reference materials (standard spiked polymers).

iv) Commercial availability of passive sampling products.

v) Determination of lipid-polymer partition coefficients to enable conversion of EQS biota from $C_{w}$.

vi) SR and LDPE are best candidate PSDs, however, there are currently no commercial suppliers.

vii) Multi-phase inter-laboratory studies to test participant proficiency, then compare and validate methodologies for field deployments, analysis and $C_{w}$ calculation (for hydrophobic EU Water Framework Directive priority substances). 
viii) Example field deployments comparing the application of passive sampling alongside grab sampling and biota monitoring.

ix) Development of assessment criteria in relation to EQSs.

The obstacles these steps seek to overcome have been discussed by others [4, 10, 232, 360], particularly data quality requirements. A comprehensive description of which is provided by Booij et al. [10]. Progress towards inclusion in compliance monitoring continues and an initial inter-laboratory study has taken place [64]. As the 2019 Water Framework Directive review approaches, a realignment to holistic monitoring of a water body's chemical status is underway. Discussing this, Brack et al. [215] recommend the adoption of passive sampling in revisions of the Directive - particularly as a proxy or to compliment biota monitoring and encourage the development of quality assessment criteria and procedures to convert passive sampling measurements into EQS.

\section{Conclusions and future trends}

Over the last 15 years, theoretical and technical advances within the field of passive sampling have incrementally increased the utility and performance of the method with respect to monitoring HOCs in aqueous environments. These advances have been derived from the efforts of a global, but relatively small, research community. Several devices have sustained interest and remain in use, however, as novel devices have been proposed and adopted, others have fallen into obsolescence. Trends in the appropriateness of the remaining devices for various applications have emerged. It was expected that the commercial availability of SPME would reduce the barriers to its adoption in the passive sampling of aqueous phase HOCs. However, only a modest number of applications have been described, focusing on determining the analytical performance of the device. It is unclear why this is the case, particularly considering the established advantages that SPME provides. SPMDs still remain popular, despite their relative complexity of construction and extraction; this seems counterintuitive. The existence of a critical mass of data arising from previous studies may be promoting their adoption in ongoing and in future research activities. Single-phase polymeric PSDs, such as LDPE and SR are becoming increasingly used due their simplicity and high performance and compatibility with simplified analytical methods for their extraction. 
The value passive sampling can add to existing monitoring programs is through its representativeness of aqueous concentrations compared to most other methods. However, if passive sampling is to displace incumbent tools, the ease, cost and risk of adoption cannot be prohibitive. Currently the availability of diverse passive sampling products and lack of certified reference materials, prohibits the use of commonly agreed values for water-polymer partition and polymer diffusion coefficients. Until such uniform materials and values are available, capacity building will be restricted and inter-laboratory variation will persist. The use of insilico methods to rapidly determine these values for novel compounds, risks being undermined by lack of consistency in polymer formulation or by ambiguity in polymer properties between batches and over time. This is particularly important, as the growing interest in emerging contaminants will require tools to identify and attribute the toxicity of HOCs alone and in complex mixtures. This could lead to the expanded use of passive sampling coupled to qualitative chemical and toxicological analysis in effect-based screening approaches.

The accessibility of passive sampling as a monitoring tool is reduced by the current lack of consolidation and clarity in device design/application. This may also reduce the commercial incentive for suppliers to introduce certified reference materials. If pursued in isolation, future improvements to sampler performance through optimization of device design are unlikely to increase the wider appeal of passive sampling. Sacrificing a component of performance for straightforwardness (i.e. devices standardized by formulations, dimensions, durations, calculations and reporting for different applications) could increase the adoption in the shortterm, augmenting the capacity for improvement in future. It is difficult to see how this could be achieved other than through parallel deployment of standardized devices in ongoing research activities. Routine deployment of LDPE devices to develop a global network of knowledge and proficiency has been proposed in the past and may still hold merit. The timeline for future inclusion of passive sampling in regulatory monitoring programs is uncertain but will rely, however, on legislator acceptance of unconventional tools and validation and demonstration of these methods by practitioners. 


\section{Acknowledgements}

We acknowledge financial support from Southern Water Services Limited for the studentship to AT. The work was also supported by the RECETOX Research Infrastructure supported by the Czech Ministry of Education, Youth and Sports (LM2015051), and the European Structural and Investment Funds, Operational Programme Research, Development, Education (CZ.02.1.01/0.0/0.0/16_013/0001761). 


\section{References}

[1] European Commission. Priority Substances under the Water Framework Directive. Dir. 2008/105/EC, 2000

[2] ONU. Stockholm Covention on Persistent Organic Pollutants (POPs); 2009.

[3] EPA. Water Quality Criteria, Chapter 3: Water Quality Criteria. Environmental Protection Agency. Water Qual. Stand. Handb., 2017.

[4] Allan, I. J.; Vrana, B.; Greenwood, R.; Mills, G. A.; Roig, B.; Gonzalez, C. A “Toolbox” for Biological and Chemical Monitoring Requirements for the European Union's Water Framework Directive. Talanta, 2006, 69 (2 SPEC. ISS.), 302-322. https://doi.org/10.1016/j.talanta.2005.09.043.

[5] Bakir, A.; O'Connor, I. A.; Rowland, S. J.; Hendriks, A. J.; Thompson, R. C. Relative Importance of Microplastics as a Pathway for the Transfer of Hydrophobic Organic Chemicals to Marine Life. Environ. Pollut., 2016, 219, 5665. https://doi.org/10.1016/j.envpol.2016.09.046.

[6] Vrana, B.; Allan, I. J.; Greenwood, R.; Mills, G. A.; Dominiak, E.; Svensson, K.; Knutsson, J.; Morrison, G. Passive Sampling Techniques for Monitoring Pollutants in Water. TrAC - Trends Anal. Chem., 2005. https://doi.org/10.1016/j.trac.2005.06.006.

[7] Mayer, P.; Tolls, J., Hermens, J. L. M., Mackay, D. Equilibrium Sampling Devices. Environ. Sci. Technol., 2003. https://doi.org/10.1016/S0889-8561(03)00030-4.

[8] Booij, K.; Vrana, B.; Huckins, J. N. Chapter 7 Theory, Modelling and Calibration of Passive Samplers Used in Water Monitoring. In Comprehensive Analytical Chemistry; 2007; Vol. 48, pp 141-169. https://doi.org/10.1016/S0166-526X(06)48007-7.

[9] Vrana, B.; Mills, G. A.; Leonards, P. E. G.; Kotterman, M.; Weideborg, M.; Hajlová, J.; Kocourek, V.; Tomaniová, M.; Pulkrabová, J.; Suchanová, M.; et al. Field Performance of the Chemcatcher Passive Sampler for Monitoring Hydrophobic Organic Pollutants in Surface Water. J. Environ. Monit., 2010, 12 (4), 863-872. https://doi.org/10.1039/b923073d.

[10] Booij, K.; Robinson, C. D.; Burgess, R. M.; Mayer, P.; Roberts, C. A.; Ahrens, L.; Allan, I. J.; Brant, J.; Jones, L.; Kraus, U. R.; et al. Passive Sampling in Regulatory Chemical Monitoring of Nonpolar Organic Compounds in the Aquatic Environment. Environ. Sci. Technol., 2016, 50 (1), 3-17. https://doi.org/10.1021/acs.est.5b04050.

[11] Smedes, F. SSP Silicone-, Lipid-and SPMD-Water Partition Coefficients of Seventy Hydrophobic Organic Contaminants and Evaluation of the Water Concentration Calculator for SPMD; 2019; Vol. 223. https://doi.org/10.1016/j.chemosphere.2019.01.164.

[12] Pintado-Herrera, M. G.; Lara-Martín, P. A.; González-Mazo, E.; Allan, I. J. Determination of Silicone Rubber and Low-Density Polyethylene Diffusion and Polymer/Water Partition Coefficients for Emerging Contaminants. Environ. Toxicol. Chem., 2016, 35 (9), 2162-2172. https://doi.org/10.1002/etc.3390.

[13] Yates, K.; Davies, I.; Webster, L.; Pollard, P.; Lawton, L.; Moffat, C. Passive Sampling: Partition Coefficients for a Silicone Rubber Reference Phase. J. Environ. Monit., 2007, 9 (10), 1116-1121. https://doi.org/10.1039/b706716j.

[14] Smedes, F. Silicone-Water Partition Coefficients Determined by Cosolvent Method for Chlorinated Pesticides, Musks, Organo Phosphates, Phthalates and More. Chemosphere, 2018, 210, 662-671. https://doi.org/10.1016/j.chemosphere.2018.07.054.

[15] Josefsson, S.; Arp, H. P. H.; Kleja, D. B.; Enell, A.; Lundstedt, S. Determination of Polyoxymethylene (POM) Water Partition Coefficients for Oxy-PAHs and PAHs. Chemosphere, 2015, 119, 1268-1274. https://doi.org/10.1016/j.chemosphere.2014.09.102.

[16] Mills, G. A.; Fones, G. R.; Booij, K.; Greenwood, R. Passive Sampling Technologies. In Chemical Marine Monitoring: Policy Framework and Analytical Trends; 2012. https://doi.org/10.1002/9781119990826.ch13.

[17] Huckins, J. N.; Petty, J. D.; Lebo, J. A.; Almeida, F. V.; Booij, K.; Alvarez, D. A.; Cranor, W. L.; Clark, R. C.; Mogensen, B. B. Development of the Permeability/Performance Reference Compound Approach for in Situ Calibration of Semipermeable Membrane Devices. Environ. Sci. Technol., 2002.

https://doi.org/10.1021/es010991w.

[18] Booij, K.; Smedes, F. An Improved Method for Estimating in Situ Sampling Rates of Nonpolar Passive Samplers. Environ. Sci. Technol., 2010, 44 (17), 6789-6794. https://doi.org/10.1021/es101321v.

[19] Rusina, T. P.; Smedes, F.; Koblizkova, M.; Klanova, J. Calibration of Silicone Rubber Passive Samplers: Experimental and Modeled Relations between Sampling Rate and Compound Properties. Environ. Sci. Technol., 2010, 44 (1), 362-367. https://doi.org/10.1021/es900938r.

[20] Rusina, T. P.; Smedes, F.; Klanova, J. Diffusion Coefficients of Polychlorinated Biphenyls and Polycyclic Aromatic Hydrocarbons in Polydimethylsiloxane and Low-Density Polyethylene Polymers. J. Appl. Polym. Sci., 2010, 116 (3), 1803-1810. https://doi.org/10.1002/app.31704.

[21] Ouyang, G.; Pawliszyn, J. Configurations and Calibration Methods for Passive Sampling Techniques. Journal of Chromatography A. 2007. https://doi.org/10.1016/j.chroma.2007.01.133.

[22] Ter Laak, T. L.; Busser, F. J. M.; Hermens, J. L. M. Poly(Dimethylsiloxane) as Passive Sampler Material for Hydrophobic Chemicals: Effect of Chemical Properties and Sampler Characteristics on Partitioning and Equilibration Times. Anal. Chem., 2008, 80 (10), 3859-3866. https://doi.org/10.1021/ac800258j.

[23] Cornelissen, G.; Pettersen, A.; Broman, D.; Mayer, P.; Breedveld, G. D. Field Testing of Equilibrium Passive Samplers to Determine Freely Dissolved Native Polycyclic Aromatic Hydrocarbon Concentrations. Environ. Toxicol. Chem., 2008, 27 (3), 499-508. https://doi.org/10.1897/07-253.1.

[24] Arp, H. P. H.; Hale, S. E.; Elmquist Kruså, M.; Cornelissen, G.; Grabanski, C. B.; Miller, D. J.; Hawthorne, S. B. Review of Polyoxymethylene Passive Sampling Methods for Quantifying Freely Dissolved Porewater 
Concentrations of Hydrophobic Organic Contaminants. Environ. Toxicol. Chem., 2015, 34 (4), 710-720. https://doi.org/10.1002/etc.2864.

[25] Greenwood, R.; Mills, G. A.; Vrana, B.; Allan, I.; Aguilar-Martínez, R.; Morrison, G. Chapter 9 Monitoring of Priority Pollutants in Water Using Chemcatcher Passive Sampling Devices. Comprehensive Analytical Chemistry. 2007, pp 199-229. https://doi.org/10.1016/S0166-526X(06)48009-0.

[26] Vrana, B.; Rusina, T.; Okonski, K.; Prokeš, R.; Carlsson, P.; Kopp, R.; Smedes, F. Chasing Equilibrium Passive Sampling of Hydrophobic Organic Compounds in Water. Sci. Total Environ., 2019, 664, 424-435. https://doi.org/10.1016/j.scitotenv.2019.01.242

[27] Gao, X.; Xu, Y.; Ma, M.; Rao, K.; Wang, Z. Simultaneous Passive Sampling of Hydrophilic and Hydrophobic Emerging Organic Contaminants in Water. Ecotoxicol. Environ. Saf., 2019, 178, 25-32. https://doi.org/https://doi.org/10.1016/j.ecoenv.2019.04.014.

[28] Jeong, Y.; Schäffer, A.; Smith, K. Comparison of the Sampling Rates and Partitioning Behaviour of Polar and NonPolar Contaminants in the Polar Organic Chemical Integrative Sampler and a Monophasic Mixed Polymer Sampler for Application as an Equilibrium Passive Sampler. Sci. Total Environ., 2018, 627, 905-915. https://doi.org/10.1016/j.scitotenv.2018.01.273.

[29] Nabi, D.; Arey, J. S. Predicting Partitioning and Diffusion Properties of Nonpolar Chemicals in Biotic Media and Passive Sampler Phases by GC × GC. Environ. Sci. Technol., 2017, 51 (5), 3001-3011. https://doi.org/10.1021/acs.est.6b05071.

[30] Liu, H.; Wei, M.; Yang, X.; Yin, C.; He, X. Development of TLSER Model and QSAR Model for Predicting Partition Coefficients of Hydrophobic Organic Chemicals between Low Density Polyethylene Film and Water. Sci. Total Environ., 2017, 574, 1371-1378. https://doi.org/10.1016/j.scitotenv.2016.08.051.

[31] Lin, W.; Jiang, R.; Shen, Y.; Xiong, Y.; Hu, S.; Xu, J.; Ouyang, G. Effect of Dissolved Organic Matter on PreEquilibrium Passive Sampling: A Predictive QSAR Modeling Study. Sci. Total Environ., 2018, 635, 53-59. https://doi.org/10.1016/j.scitotenv.2018.04.116.

[32] Miège, C.; Mazzella, N.; Allan, I.; Dulio, V.; Smedes, F.; Tixier, C.; Vermeirssen, E.; Brant, J.; O’Toole, S.; Budzinski, H.; et al. Position Paper on Passive Sampling Techniques for the Monitoring of Contaminants in the Aquatic Environment - Achievements to Date and Perspectives. Trends Environ. Anal. Chem., 2015. https://doi.org/10.1016/j.teac.2015.07.001.

[33] Allan, I. J.; Booij, K.; Paschke, A.; Vrana, B.; Mills, G. A.; Greenwood, R. Short-Term Exposure Testing of Six Different Passive Samplers for the Monitoring of Hydrophobic Contaminants in Water. J. Environ. Monit., 2010, 12 (3), 696-703. https://doi.org/10.1039/b921326k.

[34] Harman, C.; Booij, K. Letter to the Editor Concerning the Viewpoint; "Recognizing the Limitations of Performance Reference Compound (PRC)-Calibration Technique in Passive Water Sampling." Environmental Science and Technology. 2014. https://doi.org/10.1021/es405153c.

[35] Huckins, J. N.; Booij, K.; Cranor, W. L.; Alvarez, D. A.; Gale, R. W.; Bartkow, M. E.; Robertson, G. L.; Clark, R C.; Stewart, R. E. Fundamentals of the Use of Performance Reference Compounds (PRCs) in Passive Samplers. Proc. SETAC North Am. 26th Annu. Meet., 2005.

[36] Vrana, B.; Mills, G. A.; Kotterman, M.; Leonards, P.; Booij, K.; Greenwood, R. Modelling and Field Application of the Chemcatcher Passive Sampler Calibration Data for the Monitoring of Hydrophobic Organic Pollutants in Water. Environ. Pollut., 2007, 145 (3), 895-904. https://doi.org/10.1016/j.envpol.2006.04.030.

[37] Booij, K.; Hofmans, H. E.; Fischer, C. V.; Van Weerlee, E. M. Temperature-Dependent Uptake Rates of Nonpolar Organic Compounds by Semipermeable Membrane Devices and Low-Density Polyethylene Membranes. Environ. Sci. Technol., 2003. https://doi.org/10.1021/es025739i.

[38] Stuer-Lauridsen, F. Review of Passive Accumulation Devices for Monitoring Organic Micropollutants in the Aquatic Environment. Environ. Pollut., 2005. https://doi.org/10.1016/j.envpol.2004.12.004.

[39] Rummel, C. D.; Jahnke, A.; Gorokhova, E.; Kühnel, D.; Schmitt-Jansen, M. Impacts of Biofilm Formation on the Fate and Potential Effects of Microplastic in the Aquatic Environment. Environmental Science and Technology Letters. 2017. https://doi.org/10.1021/acs.estlett.7b00164.

[40] Booij, K.; van Bommel, R.; Mets, A.; Dekker, R. Little Effect of Excessive Biofouling on the Uptake of Organic Contaminants by Semipermeable Membrane Devices. Chemosphere, 2006, 65 (11), 2485-2492. https://doi.org/10.1016/j.chemosphere.2006.04.033.

[41] Richardson, B. J.; Lam, P. K. S.; Zheng, G. J.; McClellan, K. E.; De Luca-Abbott, S. B. Biofouling Confounds the Uptake of Trace Organic Contaminants by Semi-Permeable Membrane Devices (SPMDs). Mar. Pollut. Bull., 2002. https://doi.org/10.1016/S0025-326X(02)00263-1.

[42] Richardson, B. J.; De Luca Abbott, S. B.; McClellan, K. E.; Zheng, G. J.; Lam, P. K. S. The Use of Permeability Reference Compounds in Biofouled Semi-Permeable Membrane Devices (SPMDs): A Laboratory-Based Investigation. Mar. Pollut. Bull., 2008, 56 (9), 1663-1667. https://doi.org/10.1016/j.marpolbul.2008.05.012.

[43] Harman, C.; Bøyum, O.; Thomas, K. V; Grung, M. Small but Different Effect of Fouling on the Uptake Rates of Semipermeable Membrane Devices and Polar Organic Chemical Integrative Samplers. Environ. Toxicol. Chem., 2009, 28 (11), 2324-2332. https://doi.org/10.1897/09-090.1.

[44] Birch, H.; Hammershøj, R.; Mayer, P. Determining Biodegradation Kinetics of Hydrocarbons at Low Concentrations: Covering 5 and 9 Orders of Magnitude of Kow and Kaw. Environ. Sci. Technol., 2018. https://doi.org/10.1021/acs.est.7b05624.

[45] Tcaciuc, A. P.; Borrelli, R.; Zaninetta, L. M.; Gschwend, P. M. Passive Sampling of DDT, DDE and DDD in Sediments: Accounting for Degradation Processes with Reaction-Diffusion Modeling. Environ. Sci. Process. Impacts, 2018, 20 (1), 220-231. https://doi.org/10.1039/C7EM00501F.

[46] Margoum, C.; Morin, S.; Mazzella, N. Potential Toxicity of Pesticides in Freshwater Environments: Passive 
Sampling, Exposure and Impacts on Biofilms: The PoToMAC Project. Environ. Sci. Pollut. Res., 2015, 22 (6), 3985-3987. https://doi.org/10.1007/s11356-014-3291-z.

[47] Allan, I. J.; Jenssen, M. T. S. A Case of Anisotropic Exchange of Non-Polar Chemicals with Absorption-Based Passive Samplers in Water. Chemosphere, 2019, 224, 455-460. https://doi.org/10.1016/j.chemosphere.2019.02.135.

[48] Jahnke, A.; Witt, G.; Schäfer, S.; Haase, N.; Escher, B. I. Combining Passive Sampling with Toxicological Characterization of Complex Mixtures of Pollutants from the Aquatic Environment. In Advances in Biochemical Engineering/Biotechnology; 2017. https://doi.org/10.1007/10_2015_5014.

[49] Brack, W.; Ait-Aissa, S.; Burgess, R. M.; Busch, W.; Creusot, N.; Di Paolo, C.; Escher, B. I.; Mark Hewitt, L.; Hilscherova, K.; Hollender, J.; et al. Effect-Directed Analysis Supporting Monitoring of Aquatic Environments - An in-Depth Overview. Science of the Total Environment. 2016. https://doi.org/10.1016/j.scitotenv.2015.11.102.

[50] Wernersson, A. S.; Carere, M.; Maggi, C.; Tusil, P.; Soldan, P.; James, A.; Sanchez, W.; Dulio, V.; Broeg, K.; Reifferscheid, G.; et al. The European Technical Report on Aquatic Effect-Based Monitoring Tools under the Water Framework Directive. Environ. Sci. Eur., 2015. https://doi.org/10.1186/s12302-015-0039-4.

[51] Burgess, R. M.; Ho, K. T.; Brack, W.; Lamoree, M. Effects-Directed Analysis (EDA) and Toxicity Identification Evaluation (TIE): Complementary but Different Approaches for Diagnosing Causes of Environmental Toxicity. Environ. Toxicol. Chem., 2013. https://doi.org/10.1002/etc.2299.

[52] Bergmann, A. J.; Tanguay, R. L.; Anderson, K. A. Using Passive Sampling and Zebrafish to Identify Developmental Toxicants in Complex Mixtures. Environ. Toxicol. Chem., 2017, 36 (9), 2290-2298. https://doi.org/10.1002/etc.3802.

[53] Allinson, M.; Kadokami, K.; Shiraishi, F.; Nakajima, D.; Zhang, J.; Knight, A.; Gray, S. R.; Scales, P. J.; Allinson, G. Wastewater Recycling in Antarctica: Performance Assessment of an Advanced Water Treatment Plant in Removing Trace Organic Chemicals. J. Environ. Manage., 2018, 224, 122-129. https://doi.org/10.1016/j.jenvman.2018.07.020.

[54] Novák, J.; Vrana, B.; Rusina, T.; Okonski, K.; Grabic, R.; Neale, P. A.; Escher, B. I.; Macová, M.; Ait-Aissa, S.; Creusot, N.; et al. Effect-Based Monitoring of the Danube River Using Mobile Passive Sampling. Sci. Total Environ., 2018, 636, 1608-1619. https://doi.org/10.1016/j.scitotenv.2018.02.201.

[55] Toušová, Z.; Vrana, B.; Smutná, M.; Novák, J.; Klučárová, V.; Grabic, R.; Slobodník, J.; Giesy, J. P.; Hilscherová, K. Analytical and Bioanalytical Assessments of Organic Micropollutants in the Bosna River Using a Combination of Passive Sampling, Bioassays and Multi-Residue Analysis. Sci. Total Environ., 2019, 650, 1599-1612. https://doi.org/10.1016/j.scitotenv.2018.08.336.

[56] Claessens, M.; Monteyne, E.; Wille, K.; Vanhaecke, L.; Roose, P.; Janssen, C. R. Passive Sampling Reversed: Coupling Passive Field Sampling with Passive Lab Dosing to Assess the Ecotoxicity of Mixtures Present in the Marine Environment. Mar. Pollut. Bull., 2015, 93 (1-2), 9-19. https://doi.org/10.1016/j.marpolbul.2015.02.028.

[57] Bryant Jr., W. L.; Goodbred, S. L. The Response of Hydrophobic Organics and Potential Toxicity in Streams to Urbanization of Watersheds in Six Metropolitan Areas of the United States. Environ. Monit. Assess., 2009, 157 (14), 419-447. https://doi.org/10.1007/s10661-008-0546-5.

[58] Alvarez, D. A.; Cranor, W. L.; Perkins, S. D.; Clark, R. C.; Smith, S. B. Chemical and Toxicologic Assessment of Organic Contaminants in Surface Water Using Passive Samplers. J. Environ. Qual., 2008, 37 (3), 1024-1033. https://doi.org/10.2134/jeq2006.0463.

[59] Buschini, A.; Giordani, F.; Pellacani, C.; Rossi, C.; Poli, P. Cytotoxic and Genotoxic Potential of Drinking Water: A Comparison between Two Different Concentration Methods. Water Res., 2008, 42 (8-9), 1999-2006. https://doi.org/10.1016/j.watres.2007.12.005.

[60] Rastall, A. C.; Getting, D.; Goddard, J.; Roberts, D. R.; Erdinger, L. A Biomimetic Approach to the Detection and Identification of Estrogen Receptor Agonists in Surface Waters Using Semipermeable Membrane Devices (SPMDs) and Bioassay-Directed Chemical Analysis. Environ. Sci. Pollut. Res., 2006, 13 (4), 256-267. https://doi.org/10.1065/espr2005.12.290.

[61] Chung, I.-Y.; Park, Y.-M.; Lee, H.-J.; Kim, H.; Kim, D.-H.; Kim, I.-G.; Kim, S.-M.; Do, Y.-S.; Seok, K.-S.; Kwon, J.-H. Nontarget Screening Using Passive Air and Water Sampling with a Level II Fugacity Model to Identify Unregulated Environmental Contaminants. J. Environ. Sci. (China), 2017, 62, 84-91. https://doi.org/10.1016/j.jes.2017.06.036.

[62] Allinson, G.; Allinson, M.; Kadokami, K. Combining Passive Sampling with a GC-MS-Database Screening Tool to Assess Trace Organic Contamination of Rivers: A Pilot Study in Melbourne, Australia. Water. Air. Soil Pollut., 2015, 226 (7). https://doi.org/10.1007/s11270-015-2423-5.

[63] Allan, I. J.; Harman, C.; Ranneklev, S. B.; Thomas, K. V; Grung, M. Passive Sampling for Target and Nontarget Analyses of Moderately Polar and Nonpolar Substances in Water. Environ. Toxicol. Chem., 2013, 32 (8), 17181726. https://doi.org/10.1002/etc.2260.

[64] Vrana, B.; Smedes, F.; Prokeš, R.; Loos, R.; Mazzella, N.; Miege, C.; Budzinski, H.; Vermeirssen, E.; Ocelka, T.; Gravell, A.; et al. An Interlaboratory Study on Passive Sampling of Emerging Water Pollutants. TrAC - Trends Anal. Chem., 2016, 76, 153-165. https://doi.org/10.1016/j.trac.2015.10.013.

[65] Adams, R. G.; Lohmann, R.; Fernandez, L. A.; MacFarlane, J. K.; Gschwend, P. M. Polyethylene Devices: Passive Samplers for Measuring Dissolved Hydrophobic Organic Compounds in Aquatic Environments. Environ. Sci. Technol., 2007, 41 (4), 1317-1323. https://doi.org/10.1021/es0621593.

[66] Rusina, T. P.; Smedes, F.; Klanova, J.; Booij, K.; Holoubek, I. Polymer Selection for Passive Sampling: A Comparison of Critical Properties. Chemosphere, 2007, 68 (7), 1344-1351. https://doi.org/10.1016/j.chemosphere.2007.01.025.

[67] Esteve-Turrillas, F. A.; Yusà, V.; Pastor, A.; de la Guardia, M. New Perspectives in the Use of Semipermeable Membrane Devices as Passive Samplers. Talanta, 2008, 74 (4), 443-457. 
https://doi.org/10.1016/j.talanta.2007.06.019.

[68] Alvarez, D. A. Estimated Water Concentration Calculator from SPMD Data Using Multiple PRCs: Version 5.1. Microsoft Excel Spreadsheet, 2010.

[69] Allan, I. J.; Booij, K.; Paschke, A.; Vrana, B.; Mills, G. A.; Greenwood, R. Field Performance of Seven Passive Sampling Devices for Monitoring of Hydrophobic Substances. Environ. Sci. Technol., 2009, 43 (14), 5383-5390. https://doi.org/10.1021/es900608w.

[70] Djedjibegovic, J.; Marjanovic, A.; Sober, M.; Skrbo, A.; Sinanovic, K.; Larssen, T.; Grung, M.; Fjeld, E.; Rognerud, S. Levels of Persistent Organic Pollutants in the Neretva River (Bosnia and Herzegovina) Determined by Deployment of Semipermeable Membrane Devices (SPMD). J. Environ. Sci. Heal. - Part B Pestic. Food Contam. Agric. Wastes, 2010, 45 (2), 128-136. https://doi.org/10.1080/03601230903472017.

[71] Smedes, F.; Booij, K. Guidelines for Passive Sampling of Hydrophobic Contaminants in Water Using Silicone Rubber Samplers International Council for the Exploration of the Sea Conseil International Pour l'Exploration de La Mer. Ices Tech. Mar. E Environ. Sci., 2012, 52.

[72] Lohmann, R.; Muir, D. Global Aquatic Passive Sampling (AQUA-GAPS): Using Passive Samplers to Monitor POPs in the Waters of the World. Environ. Sci. Technol., 2010, 44 (3), 860-864. https://doi.org/10.1021/es902379g.

[73] O'Brien, D.; Komarova, T.; Mueller, J. F. Determination of Deployment Specific Chemical Uptake Rates for SPMD and PDMS Using a Passive Flow Monitor. Mar. Pollut. Bull., 2012, 64 (5), 1005-1011. https://doi.org/10.1016/j.marpolbul.2012.02.004.

[74] Emelogu, E. S.; Pollard, P.; Dymond, P.; Robinson, C. D.; Webster, L.; McKenzie, C.; Dobson, J.; Bresnan, E.; Moffat, C. F. Occurrence and Potential Combined Toxicity of Dissolved Organic Contaminants in the Forth Estuary and Firth of Forth, Scotland Assessed Using Passive Samplers and an Algal Toxicity Test. Sci. Total Environ., 2013, 461-462, 230-239. https://doi.org/10.1016/j.scitotenv.2013.05.011.

[75] Smedes, F.; Geertsma, R. W.; Van Der Zande, T.; Booij, K. Polymer-Water Partition Coefficients of Hydrophobic Compounds for Passive Sampling: Application of Cosolvent Models for Validation. Environ. Sci. Technol., 2009, 43 (18), 7047-7054. https://doi.org/10.1021/es9009376.

[76] Zhu, T.; Jafvert, C. T.; Fu, D.; Hu, Y. A Novel Method for Measuring Polymer-Water Partition Coefficients. Chemosphere, 2015, 138, 973-979. https://doi.org/10.1016/j.chemosphere.2014.12.040.

[77] Hale, S. E.; Martin, T. J.; Goss, K.-U.; Arp, H. P. H.; Werner, D. Partitioning of Organochlorine Pesticides from Water to Polyethylene Passive Samplers. Environ. Pollut., 2010, 158 (7), 2511-2517. https://doi.org/10.1016/j.envpol.2010.03.010.

[78] Müller, J. F.; Manomanii, K.; Mortimer, M. R.; McLachlan, M. S. Partitioning of Polycyclic Aromatic Hydrocarbons in the Polyethylene/Water System. Anal. Bioanal. Chem., 2001. https://doi.org/10.1007/s002160101025.

[79] Perron, M. M.; Burgess, R. M.; Suuberg, E. M.; Cantwell, M. G.; Pennell, K. G. Performance of Passive Samplers for Monitoring Estuarine Water Column Concentrations: 1. Contaminants of Concern. Environ. Toxicol. Chem., 2013, 32 (10), 2182-2189. https://doi.org/10.1002/etc.2321.

[80] Vrana, B.; Mills, G.; Greenwood, R.; Knutsson, J.; Svensson, K.; Morrison, G. Performance Optimisation of a Passive Sampler for Monitoring Hydrophobic Organic Pollutants in Water. J. Environ. Monit., 2005, 7 (6), 612620. https://doi.org/10.1039/b419070j.

[81] Petersen, J.; Paschke, A.; Gunold, R.; Schüürmann, G. Calibration of Chemcatcher ${ }^{\circledR}$ Passive Sampler for Selected Highly Hydrophobic Organic Substances under Fresh and Sea Water Conditions. Environ. Sci. Water Res. Technol., 2015, 1 (2), 218-226. https://doi.org/10.1039/c4ew00043a.

[82] Vrana, B.; Mills, G. A.; Dominiak, E.; Greenwood, R. Calibration of the Chemcatcher Passive Sampler for the Monitoring of Priority Organic Pollutants in Water. Environ. Pollut., 2006, 142 (2), 333-343. https://doi.org/10.1016/j.envpol.2005.10.033.

[83] de la Cal, A.; Kuster, M.; de Alda, M. L.; Eljarrat, E.; Barceló, D. Evaluation of the Aquatic Passive Sampler Chemcatcher for the Monitoring of Highly Hydrophobic Compounds in Water. Talanta, 2008, 76 (2), 327-332. https://doi.org/10.1016/j.talanta.2008.02.049.

[84] Difilippo, E. L.; Eganhouse, R. P. Assessment of PDMS-Water Partition Coefficients: Implications for Passive Environmental Sampling of Hydrophobic Organic Compounds. Environ. Sci. Technol., 2010, 44 (18), 6917-6925. https://doi.org/10.1021/es101103x.

[85] Ouyang, G.; Zhao, W.; Bragg, L.; Qin, Z.; Alaee, M.; Pawliszyn, J. Time-Weighted Average Water Sampling in Lake Ontario with Solid-Phase Microextraction Passive Samplers. Environ. Sci. Technol., 2007, 41 (11), 40264031. https://doi.org/10.1021/es062647a.

[86] Hawthorne, S. B.; Jonker, M. T. O.; Van Der Heijden, S. A.; Grabanski, C. B.; Azzolina, N. A.; Miller, D. J. Measuring Picogram per Liter Concentrations of Freely Dissolved Parent and Alkyl PAHs (PAH-34), Using Passive Sampling with Polyoxymethylene. Anal. Chem., 2011, 83 (17), 6754-6761. https://doi.org/10.1021/ac201411v.

[87] Endo, S.; Hale, S. E.; Goss, K.-U.; Arp, H. P. H. Equilibrium Partition Coefficients of Diverse Polar and Nonpolar Organic Compounds to Polyoxymethylene (POM) Passive Sampling Devices. Environ. Sci. Technol., 2011, 45 (23), 10124-10132. https://doi.org/10.1021/es202894k.

[88] Cui, X.; Mayer, P.; Gan, J. Methods to Assess Bioavailability of Hydrophobic Organic Contaminants: Principles, Operations, and Limitations. Environ. Pollut., 2013, 172, 223-234. https://doi.org/10.1016/j.envpol.2012.09.013.

[89] Belles, A.; Alary, C.; Mamindy-Pajany, Y. Thickness and Material Selection of Polymeric Passive Samplers for Polycyclic Aromatic Hydrocarbons in Water: Which More Strongly Affects Sampler Properties? Environ. Toxicol. Chem., 2016, 35 (7), 1708-1717. https://doi.org/10.1002/etc.3326.

[90] Huckins, J. N.; Tubergen, M. W.; Manuweera, G. K. Semipermeable Membrane Devices Containing Model Lipid: A New Approach to Monitoring the Bioavaiiability of Lipophilic Contaminants and Estimating Their 
Bioconcentration Potential. Chemosphere, 1990. https://doi.org/10.1016/0045-6535(90)90110-F.

[91] Huckins, J. N.; Petty, J. D.; Booij, K. Monitors of Organic Chemicals in the Environment: Semipermeable Membrane Devices; 2006. https://doi.org/10.1007/0-387-35414-X.

[92] Booij, K.; Smedes, F.; Van Weerlee, E. M.; Honkoop, P. J. C. Environmental Monitoring of Hydrophobic Organic Contaminants: The Case of Mussels versus Semipermeable Membrane Devices. Environ. Sci. Technol., 2006, 40 (12), 3893-3900. https://doi.org/10.1021/es052492r.

[93] Booij, K.; Sleiderink, H. M.; Smedes, F. Calibrating the Uptake Kinetics of Semipermeable Membrane Devices Using Exposure Standards. Environ. Toxicol. Chem., 1998. https://doi.org/10.1897/15515028(1998)017<1236:CTUKOS>2.3.CO;2.

[94] Alvarez, D. A. Development of Semipermeable Membrane Devices (SPMDs) and Polar Organic Chemical Integrative Samplers (POCIS) for Environmental Monitoring. Environ. Toxicol. Chem., 2013, 32 (10), $2179-2181$. https://doi.org/10.1002/etc.2339.

[95] Martin, A.; Margoum, C.; Randon, J.; Coquery, M. Silicone Rubber Selection for Passive Sampling of Pesticides in Water. Talanta, 2016, 160, 306-313. https://doi.org/10.1016/j.talanta.2016.07.019.

[96] Vrana, B.; Komancová, L.; Sobotka, J. Calibration of a Passive Sampler Based on Stir Bar Sorptive Extraction for the Monitoring of Hydrophobic Organic Pollutants in Water. Talanta, 2016, 152, 90-97.

https://doi.org/10.1016/j.talanta.2016.01.040.

[97] Da Silva, D. S.; Brenner, C. G. B.; Mayer, F. M.; Montipó, S.; Martins, A. F. PDMS Extraction Bars for the Determination of Volatile Aromatic Hydrocarbons in Water and Wastewater. J. Sep. Sci., 2013, 36 (2), 362-368. https://doi.org/10.1002/jssc.201200491.

[98] van Pinxteren, M.; Paschke, A.; Popp, P. Silicone Rod and Silicone Tube Sorptive Extraction. J. Chromatogr. A, 2010, 1217 (16), 2589-2598. https://doi.org/10.1016/j.chroma.2009.11.025.

[99] Martin, A.; Margoum, C.; Jolivet, A.; Assoumani, A.; El Moujahid, B.; Randon, J.; Coquery, M. Calibration of Silicone Rubber Rods as Passive Samplers for Pesticides at Two Different Flow Velocities: Modeling of Sampling Rates under Water Boundary Layer and Polymer Control. Environ. Toxicol. Chem., 2018, 37 (4), 1208-1218. https://doi.org/10.1002/etc.4050.

[100] QUASIMEME. Quasimeme Laboratory Performance Studies, Program 2019 http://www.quasimeme.org/gfx_content/documents/Brochure quasimeme 2019.pdf (accessed Jun 29, 2019).

[101] Lohmann, R. Critical Review of Low-Density Polyethylene's Partitioning and Diffusion Coefficients for Trace Organic Contaminants and Implications for Its Use as a Passive Sampler. Environ. Sci. Technol., 2012, 46 (2), 606 618. https://doi.org/10.1021/es202702y.

[102] Kingston, J. K.; Greenwood, R.; Mills, G. A.; Morrison, G. M.; Persson, L. B. Development of a Novel Passive Sampling System for the Time-Averaged Measurement of a Range of Organic Pollutants in Aquatic Environments. J. Environ. Monit., 2000. https://doi.org/10.1039/b003532g.

[103] Lobpreis, T.; Vrana, B.; Dominiak, E.; Dercová, K.; Mills, G. A.; Greenwood, R. Effect of Housing Geometry on the Performance of Chemcatcher ${ }^{\mathrm{TM}}$ Passive Sampler for the Monitoring of Hydrophobic Organic Pollutants in Water. Environ. Pollut., 2008, 153 (3), 706-710. https://doi.org/10.1016/j.envpol.2007.09.011.

[104] Pawliszyn, J.; Arthur, C. L. Solid Phase Microextraction with Thermal Desorption Using Fused Silica Optical Fibers. Anal. Chem., 1990. https://doi.org/10.1021/ac00218a019.

[105] Ouyang, G.; Pawliszyn, J. Recent Developments in SPME for On-Site Analysis and Monitoring. TrAC - Trends Anal. Chem., 2006. https://doi.org/10.1016/j.trac.2006.05.005.

[106] Duan, C.; Shen, Z.; Wu, D.; Guan, Y. Recent Developments in Solid-Phase Microextraction for on-Site Sampling and Sample Preparation. TrAC Trends Anal. Chem., 2011, 30 (10), 1568-1574. https://doi.org/https://doi.org/10.1016/j.trac.2011.08.005.

[107] Piri-Moghadam, H.; Ahmadi, F.; Pawliszyn, J. A Critical Review of Solid Phase Microextraction for Analysis of Water Samples. TrAC Trends Anal. Chem., 2016, 85, 133-143. https://doi.org/https://doi.org/10.1016/j.trac.2016.05.029.

[108] Piri-Moghadam, H.; Alam, M. N.; Pawliszyn, J. Review of Geometries and Coating Materials in Solid Phase Microextraction: Opportunities, Limitations, and Future Perspectives. Anal. Chim. Acta, 2017, 984, 42-65. https://doi.org/10.1016/j.aca.2017.05.035.

[109] Reyes-Garcés, N.; Gionfriddo, E.; Gómez-Ríos, G. A.; Alam, M. N.; Boyacl, E.; Bojko, B.; Singh, V.; Grandy, J.; Pawliszyn, J. Advances in Solid Phase Microextraction and Perspective on Future Directions. Anal. Chem., 2018, 90 (1), 302-360. https://doi.org/10.1021/acs.analchem.7b04502.

[110] Sajid, M.; Khaled Nazal, M.; Rutkowska, M.; Szczepańska, N.; Namieśnik, J.; Płotka-Wasylka, J. Solid Phase Microextraction: Apparatus, Sorbent Materials, and Application. Crit. Rev. Anal. Chem., 2019, 49 (3), 271-288. https://doi.org/10.1080/10408347.2018.1517035.

[111] Chen, Y.; Pawliszyn, J. Kinetics and the On-Site Application of Standards in a Solid-Phase Microextration Fiber. Anal. Chem., 2004. https://doi.org/10.1021/ac0495081.

[112] Lin, K.; Lao, W.; Lu, Z.; Jia, F.; Maruya, K.; Gan, J. Measuring Freely Dissolved DDT and Metabolites in Seawater Using Solid-Phase Microextraction with Performance Reference Compounds. Sci. Total Environ., 2017, 599-600, 364-371. https://doi.org/10.1016/j.scitotenv.2017.05.022.

[113] Pawliszyn, J. Handbook of Solid Phase Microextraction; 2012. https://doi.org/10.1016/C2011-0-04297-7.

[114] Cornelissen, G.; Broman, D.; Næs, K. Freely Dissolved PCDDF/F Concentrations in the Frierfjord, Norway: Comparing Equilibrium Passive Sampling with “Active” Water Sampling. J. Soils Sediments, 2010, 10 (2), 162171. https://doi.org/10.1007/s11368-009-0152-3.

[115] Martin, A.; Margoum, C.; Coquery, M.; Randon, J. Combination of Sorption Properties of Polydimethylsiloxane and Solid-Phase Extraction Sorbents in a Single Composite Material for the Passive Sampling of Polar and Apolar 
Pesticides in Water. J. Sep. Sci., 2016, 39 (20), 3990-3997. https://doi.org/10.1002/jssc.201600502.

[116] Hale, S. E.; Endo, S.; Arp, H. P. H.; Zimmerman, A. R.; Cornelissen, G. Sorption of the Monoterpenes $\alpha$-Pinene and Limonene to Carbonaceous Geosorbents Including Biochar. Chemosphere, 2015, 119, 881-888. https://doi.org/10.1016/j.chemosphere.2014.08.052.

[117] Hale, S. E.; Tomaszewski, J. E.; Luthy, R. G.; Werner, D. Sorption of Dichlorodiphenyltrichloroethane (DDT) and Its Metabolites by Activated Carbon in Clean Water and Sediment Slurries. Water Res., 2009, 43 (17), 4336-4346. https://doi.org/10.1016/j.watres.2009.06.031.

[118] Thomas, C.; Lampert, D.; Reible, D. Remedy Performance Monitoring at Contaminated Sediment Sites Using Profiling Solid Phase Microextraction (SPME) Polydimethylsiloxane (PDMS) Fibers. Environ. Sci. Process. Impacts, 2014, 16 (3), 445-452. https://doi.org/10.1039/c3em00695f.

[119] Wang, P.; Liu, X.; Wu, X.; Xu, J.; Dong, F.; Zheng, Y. Evaluation of Biochars in Reducing the Bioavailability of Flubendiamide in Water/Sediment Using Passive Sampling with Polyoxymethylene. J. Hazard. Mater., 2018, 344 , 1000-1006. https://doi.org/10.1016/j.jhazmat.2017.12.003.

[120] Beckingham, B.; Ghosh, U. Polyoxymethylene Passive Samplers to Monitor Changes in Bioavailability and Flux of PCBs after Activated Carbon Amendment to Sediment in the Field. Chemosphere, 2013, 91 (10), 1401-1407. https://doi.org/10.1016/j.chemosphere.2012.12.074.

[121] Dou, Y.; Zhang, T. C.; Zeng, J.; Stansbury, J.; Moussavi, M.; Richter-Egger, D. L.; Klein, M. R. Polyurethane Foam (PUF) Passive Samplers for Monitoring Phenanthrene in Stormwater. Environ. Sci. Process. Impacts, 2016, 18 (4), 473-481. https://doi.org/10.1039/c5em00591d.

[122] Pogorzelec, M.; Piekarska, K. Application of Semipermeable Membrane Devices for Long-Term Monitoring of Polycyclic Aromatic Hydrocarbons at Various Stages of Drinking Water Treatment. Sci. Total Environ., 2018, 631632, 1431-1439. https://doi.org/10.1016/j.scitotenv.2018.03.105.

[123] Pogorzelec, M.; Piekarska, K. Concentration of Polycyclic Aromatic Hydrocarbons in Water Samples from Different Stages of Treatment. In International Conference on Advances in Energy Systems and Environmental Engineering, ASEE 2017; J., D., H., J., B., K., M., K., K., P., Eds.; EDP Sciences: Wroclaw University of Science and Technology, Faculty of Environmental Engineering, Wybrzeze Wyspiańskiego 27, Wrocław, 50-370, Poland, 2017; Vol. 22. https://doi.org/10.1051/e3sconf/20172200135.

[124] Gilli, G.; Schilirò, T.; Pignata, C.; Traversi, D.; Carraro, E.; Baiocchi, C.; Aigotti, R.; Giacosa, D.; Fea, E. Application of Semipermeable Membrane Device for Assessing Toxicity in Drinking Water. Chemosphere, 2005, 61 (11), 1691-1699. https://doi.org/10.1016/j.chemosphere.2005.03.085.

[125] Augulyte, L.; Kliaugaite, D.; Racys, V.; Jankunaite, D.; Zaliauskiene, A.; Andersson, P. L.; Bergqvist, P.-A. Chemical and Ecotoxicological Assessment of Selected Biologically Activated Sorbents for Treating Wastewater Polluted with Petroleum Products with Special Emphasis on Polycyclic Aromatic Hydrocarbons. Water. Air. Soil Pollut., 2008, 195 (1-4), 243-256. https://doi.org/10.1007/s11270-008-9743-7.

[126] Augulyte, L.; Kliaugaite, D.; Racys, V.; Jankunaite, D.; Zaliauskiene, A.; Bergqvist, P.-A.; Andersson, P. L. Multivariate Analysis of a Biologically Activated Carbon (BAC) System and Its Efficiency for Removing PAHs and Aliphatic Hydrocarbons from Wastewater Polluted with Petroleum Products. J. Hazard. Mater., 2009, 170 (1), 103-110. https://doi.org/10.1016/j.jhazmat.2009.04.129.

[127] Chiu, J. M. Y.; Degger, N.; Leung, J. Y. S.; Po, B. H. K.; Zheng, G. J.; Richardson, B. J.; Lau, T. C.; Wu, R. S. S. A Novel Approach for Estimating the Removal Efficiencies of Endocrine Disrupting Chemicals and Heavy Metals in Wastewater Treatment Processes. Mar. Pollut. Bull., 2016, 112 (1-2), 53-57. https://doi.org/10.1016/j.marpolbul.2016.08.043.

[128] Hoque, M. E.; Cloutier, F.; Arcieri, C.; McInnes, M.; Sultana, T.; Murray, C.; Vanrolleghem, P. A.; Metcalfe, C. D. Removal of Selected Pharmaceuticals, Personal Care Products and Artificial Sweetener in an Aerated Sewage Lagoon. Sci. Total Environ., 2014, 487 (1), 801-812. https://doi.org/10.1016/j.scitotenv.2013.12.063.

[129] Gourlay-Francé, C.; Bressy, A.; Uher, E.; Lorgeoux, C. Labile, Dissolved and Particulate PAHs and Trace Metals in Wastewater: Passive Sampling, Occurrence, Partitioning in Treatment Plants. Water Sci. Technol., 2011, 63 (7), 1327-1333. https://doi.org/10.2166/wst.2011.127.

[130] Clarke, B. O.; Porter, N. A.; Symons, R. K.; Marriott, P. J.; Stevenson, G. J.; Blackbeard, J. R. Investigating the Distribution of Polybrominated Diphenyl Ethers through an Australian Wastewater Treatment Plant. Sci. Total Environ., 2010, 408 (7), 1604-1611. https://doi.org/10.1016/j.scitotenv.2009.11.059.

[131] Gourlay-Francé, C.; Lorgeoux, C.; Tusseau-Vuillemin, M.-H. Polycyclic Aromatic Hydrocarbon Sampling in Wastewaters Using Semipermeable Membrane Devices: Accuracy of Time-Weighted Average Concentration Estimations of Truly Dissolved Compounds. Chemosphere, 2008, 73 (8), 1194-1200. https://doi.org/10.1016/j.chemosphere.2008.07.049.

[132] Augulyte, L.; Bergqvist, P.-A. Estimation of Water Sampling Rates and Concentrations of PAHs in a Municipal Sewage Treatment Plant Using SPMDs with Performance Reference Compounds. Environ. Sci. Technol., 2007, 41 (14), 5044-5049. https://doi.org/10.1021/es070054+.

[133] Barber, L. B.; Keefe, S. H.; Antweiler, R. C.; Taylor, H. E.; Wass, R. D. Accumulation of Contaminants in Fish from Wastewater Treatment Wetlands. Environ. Sci. Technol., 2006, 40 (2), 603-611. https://doi.org/10.1021/es0514287.

[134] Petrie, B.; Barden, R.; Kasprzyk-Hordern, B. A Review on Emerging Contaminants in Wastewaters and the Environment: Current Knowledge, Understudied Areas and Recommendations for Future Monitoring. Water Res., 2014. https://doi.org/10.1016/j.watres.2014.08.053.

[135] UWWTD. Urban Waste Water Treatment Directive, L. 135/43, 30/05/1991. Off. J. Eur. Union, 1991, 40-52.

[136] Soares, A.; Guieysse, B.; Jefferson, B.; Cartmell, E.; Lester, J. N. Nonylphenol in the Environment: A Critical Review on Occurrence, Fate, Toxicity and Treatment in Wastewaters. Environment International. 2008. 
https://doi.org/10.1016/j.envint.2008.01.004.

[137] Hale, S. E.; Oen, A. M. P.; Cornelissen, G.; Jonker, M. T. O.; Waarum, I.-K.; Eek, E. The Role of Passive Sampling in Monitoring the Environmental Impacts of Produced Water Discharges from the Norwegian Oil and Gas Industry. Mar. Pollut. Bull., 2016, 111 (1-2), 33-40. https://doi.org/10.1016/j.marpolbul.2016.07.051.

[138] Lourenço, R. A.; de Oliveira, F. F.; de Souza, J. M.; Nudi, A. H.; de Luca Rebello Wagener, Â.; de Fátima Guadalupe Meniconi, M.; Francioni, E. Monitoring of Polycyclic Aromatic Hydrocarbons in a Produced Water Disposal Area in the Potiguar Basin, Brazilian Equatorial Margin. Environ. Sci. Pollut. Res., 2016, 23 (17), 1711317122. https://doi.org/10.1007/s11356-016-6903-y.

[139] André Lourenço, R.; Francisco de Oliveira, F.; Haddad Nudi, A.; Rebello Wagener, Â. D. L.; Guadalupe Meniconi, M. D. F.; Francioni, E. PAH Assessment in the Main Brazilian Offshore Oil and Gas Production Area Using SemiPermeable Membrane Devices (SPMD) and Transplanted Bivalves. Cont. Shelf Res., 2015, 101, 109-116. https://doi.org/10.1016/j.csr.2015.04.010.

[140] Harman, C.; Brooks, S.; Sundt, R. C.; Meier, S.; Grung, M. Field Comparison of Passive Sampling and Biological Approaches for Measuring Exposure to PAH and Alkylphenols from Offshore Produced Water Discharges. Mar. Pollut. Bull., 2011, 63 (5-12), 141-148. https://doi.org/10.1016/j.marpolbul.2010.12.023.

[141] Harman, C.; Thomas, K. V; Tollefsen, K. E.; Meier, S.; Bøyum, O.; Grung, M. Monitoring the Freely Dissolved Concentrations of Polycyclic Aromatic Hydrocarbons (PAH) and Alkylphenols (AP) around a Norwegian Oil Platform by Holistic Passive Sampling. Mar. Pollut. Bull., 2009, 58 (11), 1671-1679. https://doi.org/10.1016/j.marpolbul.2009.06.022.

[142] Durell, G.; Røe Utvik, T.; Johnsen, S.; Frost, T.; Neff, J. Oil Well Produced Water Discharges to the North Sea. Part I: Comparison of Deployed Mussels (Mytilus Edulis), Semi-Permeable Membrane Devices, and the DREAM Model Predictions to Estimate the Dispersion of Polycyclic Aromatic Hydrocarbons. Mar. Environ. Res., 2006, 62 (3), 194-223. https://doi.org/10.1016/j.marenvres.2006.03.013.

[143] Burgos, M.; Cailleaud, K. Assessment of Alternative Devices for Trace Hydrocarbon Monitoring in the Environment Around Offshore Oil and Gas Facilities. In Abu Dhabi International Petroleum Exhibition and Conference, ADIPEC 2016; Society of Petroleum Engineers: TOTAL, France, 2016; Vol. 2016-Janua. https://doi.org/10.2118/183525-ms.

[144] Orrego, R.; Hewitt, L. M.; McMaster, M.; Chiang, G.; Quiroz, M.; Munkittrick, K.; Gavilán, J. F.; Barra, R. Assessing Wild Fish Exposure to Ligands for Sex Steroid Receptors from Pulp and Paper Mill Effluents in the Biobio River Basin, Central Chile. Ecotoxicol. Environ. Saf., 2019, 171, 256-263. https://doi.org/10.1016/j.ecoenv.2018.12.092.

[145] Charlestra, L.; Courtemanch, D. L.; Amirbahman, A.; Patterson, H. Semipermeable Membrane Device (SPMD) for Monitoring PCDD and PCDF Levels from a Paper Mill Effluent in the Androscoggin River, Maine, USA.

Chemosphere, 2008, 72 (8), 1171-1180. https://doi.org/10.1016/j.chemosphere.2008.03.057.

[146] Dixon-Anderson, E.; Lohmann, R. Field-Testing Polyethylene Passive Samplers for the Detection of Neutral Polyfluorinated Alkyl Substances in Air and Water. Environ. Toxicol. Chem., 2018, 37 (12), 3002-3010. https://doi.org/10.1002/etc.4264.

[147] Estoppey, N.; Omlin, J.; Schopfer, A.; Esseiva, P.; Vermeirssen, E. L. M.; Delémont, O.; De Alencastro, L. F. Low Density Polyethylene (LDPE) Passive Samplers for the Investigation of Polychlorinated Biphenyl (PCB) Point Sources in Rivers. Chemosphere, 2015, 118 (1), 268-276. https://doi.org/10.1016/j.chemosphere.2014.09.032.

[148] Estoppey, N.; Schopfer, A.; Fong, C.; Delémont, O.; De Alencastro, L. F.; Esseiva, P. An In-Situ Assessment of Low-Density Polyethylene and Silicone Rubber Passive Samplers Using Methods with and without Performance Reference Compounds in the Context of Investigation of Polychlorinated Biphenyl Sources in Rivers. Sci. Total Environ., 2016, 572, 794-803. https://doi.org/10.1016/j.scitotenv.2016.07.092.

[149] Sultana, T.; Murray, C.; Ehsanul Hoque, M.; Metcalfe, C. D. Monitoring Contaminants of Emerging Concern from Tertiary Wastewater Treatment Plants Using Passive Sampling Modelled with Performance Reference Compounds. Environ. Monit. Assess., 2016, 189 (1). https://doi.org/10.1007/s10661-016-5706-4.

[150] Bidwell, J. R.; Becker, C.; Hensley, S.; Stark, R.; Meyer, M. T. Occurrence of Organic Wastewater and Other Contaminants in Cave Streams in Northeastern Oklahoma and Northwestern Arkansas. Arch. Environ. Contam. Toxicol., 2010, 58 (2), 286-298. https://doi.org/10.1007/s00244-009-9388-6.

[151] Grabic, R.; Jurcikova, J.; Tomsejova, S.; Ocelka, T.; Halirova, J.; Hypr, D.; Kodes, V. Passive Sampling Methods for Monitoring Endocrine Disruptors in the Svratka and Svitava Rivers in the Czech Republic. Environ. Toxicol. Chem., 2010, 29 (3), 550-555. https://doi.org/10.1002/etc.85.

[152] Balmer, M. E.; Buser, H.-R.; Müller, M. D.; Poiger, T. Occurrence of Some Organic UV Filters in Wastewater, in Surface Waters, and in Fish from Swiss Lakes. Environ. Sci. Technol., 2005, 39 (4), 953-962. https://doi.org/10.1021/es040055r.

[153] Ouyang, X.; Leonards, P.; Legler, J.; van der Oost, R.; de Boer, J.; Lamoree, M. Comprehensive Two-Dimensional Liquid Chromatography Coupled to High Resolution Time of Flight Mass Spectrometry for Chemical Characterization of Sewage Treatment Plant Effluents. J. Chromatogr. A, 2015, 1380, 139-145. https://doi.org/10.1016/j.chroma.2014.12.075.

[154] Jeong, Y.; Schäffer, A.; Smith, K. A Comparison of Equilibrium and Kinetic Passive Sampling for the Monitoring of Aquatic Organic Contaminants in German Rivers. Water Res., 2018, 145, 248-258. https://doi.org/10.1016/j.watres.2018.08.016.

[155] Yao, Y.; Meng, X.-Z.; Wu, C.-C.; Bao, L.-J.; Wang, F.; Wu, F.-C.; Zeng, E. Y. Tracking Human Footprints in Antarctica through Passive Sampling of Polycyclic Aromatic Hydrocarbons in Inland Lakes. Environ. Pollut., 2016, 213, 412-419. https://doi.org/10.1016/j.envpol.2016.02.035.

[156] Schintu, M.; Marrucci, A.; Marras, B.; Atzori, M.; Pellegrini, D. Passive Sampling Monitoring of PAHs and Trace 
Metals in Seawater during the Salvaging of the Costa Concordia Wreck (Parbuckling Project). Mar. Pollut. Bull., 2018, 135, 819-827. https://doi.org/10.1016/j.marpolbul.2018.08.011.

[157] Faksness, L.-G.; Brandvik, P. J.; Daae, R. L.; Leirvik, F.; Børseth, J. F. The Monitoring of Oil in Water and MetOcean Interactions during a Large-Scale Oil-in-Ice Experiment in the Barents Sea. In 33rd AMOP Technical Seminar on Environmental Contamination and Response; SINTEF Materials and Chemistry, Trondheim, Norway, 2010; Vol. 2, pp 679-700.

[158] O'Toole, S.; Metcalfe, C.; Craine, I.; Gross, M. Release of Persistent Organic Contaminants from Carcasses of Lake Ontario Chinook Salmon (Oncorhynchus Tshawytscha). Environ. Pollut., 2006, 140 (1), 102-113. https://doi.org/10.1016/j.envpol.2005.06.019.

[159] Tucca, F.; Moya, H.; Barra, R. Ethylene Vinyl Acetate Polymer as a Tool for Passive Sampling Monitoring of Hydrophobic Chemicals in the Salmon Farm Industry. Mar. Pollut. Bull., 2014, 88 (1-2), 174-179. https://doi.org/10.1016/j.marpolbul.2014.09.009.

[160] Mundy, L. J.; Bilodeau, J. C.; Schock, D. M.; Thomas, P. J.; Blais, J. M.; Pauli, B. D. Using Wood Frog (Lithobates Sylvaticus) Tadpoles and Semipermeable Membrane Devices to Monitor Polycyclic Aromatic Compounds in Boreal Wetlands in the Oil Sands Region of Northern Alberta, Canada. Chemosphere, 2019, 214, 148-157. https://doi.org/10.1016/j.chemosphere.2018.09.034.

[161] Uher, E.; Mirande-Bret, C.; Gourlay-Francé, C. Assessing the Relation between Anthropogenic Pressure and PAH Concentrations in Surface Water in the Seine River Basin Using Multivariate Analysis. Sci. Total Environ., 2016, 557-558, 551-561. https://doi.org/10.1016/j.scitotenv.2016.03.118.

[162] Kim, U.-J.; Kim, H. Y.; Alvarez, D.; Lee, I.-S.; Oh, J.-E. Using SPMDs for Monitoring Hydrophobic Organic Compounds in Urban River Water in Korea Compared with Using Conventional Water Grab Samples. Sci. Total Environ., 2014, 470-471, 1537-1544. https://doi.org/10.1016/j.scitotenv.2013.06.033.

[163] Allan, I. J.; Christensen, G.; Bæk, K.; Evenset, A. Photodegradation of PAHs in Passive Water Samplers. Mar. Pollut. Bull., 2016, 105 (1), 249-254. https://doi.org/10.1016/j.marpolbul.2016.02.018.

[164] Chang, W.-T.; Fang, M.-D.; Lee, C.-L.; Brimblecombe, P. Measuring Bioavailable PAHs in Estuarine Water Using Semipermeable Membrane Devices with Performance Reference Compounds. Mar. Pollut. Bull., 2014, 89 (1-2), 376-383. https://doi.org/10.1016/j.marpolbul.2014.09.031.

[165] Rosen, M. R.; Alvarez, D. A.; Goodbred, S. L.; Leiker, T. J.; Patiño, R. Sources and Distribution of Organic Compounds Using Passive Samplers in Lake Mead National Recreation Area, Nevada and Arizona, and Their Implications for Potential Effects on Aquatic Biota. J. Environ. Qual., 2010, 39 (4), 1161-1172. https://doi.org/10.2134/jeq2009.0095.

[166] Komarova, T. V; Bartkow, M. E.; Rutishauser, S.; Carter, S.; Mueller, J. F. Evaluation and in Situ Assessment of Photodegradation of Polyaromatic Hydrocarbons in Semipermeable Membrane Devices Deployed in Ocean Water. Environ. Pollut., 2009, 157 (3), 731-736. https://doi.org/10.1016/j.envpol.2008.11.040.

[167] Sun, C.; Soltwedel, T.; Bauerfeind, E.; Adelman, D. A.; Lohmann, R. Depth Profiles of Persistent Organic Pollutants in the North and Tropical Atlantic Ocean. Environ. Sci. Technol., 2016, 50 (12), 6172-6179. https://doi.org/10.1021/acs.est.5b05891.

[168] Fernandez, L. A.; Lao, W.; Maruya, K. A.; White, C.; Burgess, R. M. Passive Sampling to Measure Baseline Dissolved Persistent Organic Pollutant Concentrations in the Water Column of the Palos Verdes Shelf Superfund Site. Environ. Sci. Technol., 2012, 46 (21), 11937-11947. https://doi.org/10.1021/es302139y.

[169] Sacks, V. P.; Lohmann, R. Freely Dissolved PBDEs in Water and Porewater of an Urban Estuary. Environ. Pollut., 2012, 162, 287-293. https://doi.org/10.1016/j.envpol.2011.11.028.

[170] Aminot, Y.; Belles, A.; Alary, C.; Readman, J. W. Near-Surface Distribution of Pollutants in Coastal Waters as Assessed by Novel Polyethylene Passive Samplers. Mar. Pollut. Bull., 2017, 119 (1), 92-101. https://doi.org/10.1016/j.marpolbul.2017.03.022.

[171] Bradshaw, C.; Tjensvoll, I.; Sköld, M.; Allan, I. J.; Molvaer, J.; Magnusson, J.; Naes, K.; Nilsson, H. C. Bottom Trawling Resuspends Sediment and Releases Bioavailable Contaminants in a Polluted Fjord. Environ. Pollut., 2012, 170, 232-241. https://doi.org/10.1016/j.envpol.2012.06.019.

[172] Schaanning, M. T.; Harman, C.; Staalstrøm, A. Release of Dissolved Trace Metals and Organic Contaminants during Deep Water Disposal of Contaminated Sediments from Oslo Harbour, Norway. J. Soils Sediments, 2011, 11 (8), 1477-1489. https://doi.org/10.1007/s11368-011-0436-2.

[173] Sun, N.; Chen, Y.; Xu, S.; Zhang, Y.; Fu, Q.; Ma, L.; Wang, Q.; Chang, Y.; Man, Z. Remobilization and Bioavailability of Polycyclic Aromatic Hydrocarbons from Estuarine Sediments under the Effects of Nereis Diversicolor Bioturbation. Environ. Pollut., 2018, 242, 931-937. https://doi.org/10.1016/j.envpol.2018.07.026.

[174] Gourlay, C. Influence of organic matter on polycyclic aromatic hydrocarbons bioavailability in aquatic ecosystems . Tech. - Sci. - Methodes, 2007, No. 4, 47-59.

[175] Claessens, M.; De Laender, F.; Monteyne, E.; Roose, P.; Janssen, C. R. Modelling the Fate of Micropollutants in the Marine Environment Using Passive Sampling. Mar. Pollut. Bull., 2015, 96 (1-2), 103-109. https://doi.org/10.1016/j.marpolbul.2015.05.040.

[176] Bayen, S.; Segovia Estrada, E.; Zhang, H.; Lee, W. K.; Juhel, G.; Smedes, F.; Kelly, B. C. Partitioning and Bioaccumulation of Legacy and Emerging Hydrophobic Organic Chemicals in Mangrove Ecosystems. Environ. Sci. Technol., 2019, 53 (5), 2549-2558. https://doi.org/10.1021/acs.est.8b06122.

[177] Sobek, A.; Arp, H. P. H.; Wiberg, K.; Hedman, J.; Cornelissen, G. Aerosol-Water Distribution of PCDD/Fs and PCBs in the Baltic Sea Region. Environ. Sci. Technol., 2013, 47 (2), 781-789. https://doi.org/10.1021/es3028567.

[178] McDonough, C. A.; Puggioni, G.; Helm, P. A.; Muir, D.; Lohmann, R. Spatial Distribution and Air-Water Exchange of Organic Flame Retardants in the Lower Great Lakes. Environ. Sci. Technol., 2016, 50 (17), $9133-$ 9141. https://doi.org/10.1021/acs.est.6b02496. 
[179] Liu, Y.; Wang, S.; McDonough, C. A.; Khairy, M.; Muir, D. C. G.; Helm, P. A.; Lohmann, R. Gaseous and FreelyDissolved PCBs in the Lower Great Lakes Based on Passive Sampling: Spatial Trends and Air-Water Exchange. Environ. Sci. Technol., 2016, 50 (10), 4932-4939. https://doi.org/10.1021/acs.est.5b04586.

[180] Khairy, M.; Muir, D.; Teixeira, C.; Lohmann, R. Spatial Trends, Sources, and Air-Water Exchange of Organochlorine Pesticides in the Great Lakes Basin Using Low Density Polyethylene Passive Samplers. Environ. Sci. Technol., 2014, 48 (16), 9315-9324. https://doi.org/10.1021/es501686a.

[181] Apell, J. N.; Gschwend, P. M. The Atmosphere as a Source/Sink of Polychlorinated Biphenyls to/from the Lower Duwamish Waterway Superfund Site. Environ. Pollut., 2017, 227, 263-270. https://doi.org/10.1016/j.envpol.2017.04.070.

[182] Khairy, M. A.; Lohmann, R. Using Polyethylene Passive Samplers to Study the Partitioning and Fluxes of Polybrominated Diphenyl Ethers in an Urban River. Environ. Sci. Technol., 2017, 51 (16), 9062-9071. https://doi.org/10.1021/acs.est.7b02418.

[183] Friedman, C. L.; Cantwell, M. G.; Lohmann, R. Passive Sampling Provides Evidence for Newark Bay as a Source of Polychlorinated Dibenzo-p-Dioxins and Furans to the New York/New Jersey, USA, Atmosphere. Environ. Toxicol. Chem., 2012, 31 (2), 253-261. https://doi.org/10.1002/etc.742.

[184] Lohmann, R.; Klanova, J.; Kukucka, P.; Yonis, S.; Bollinger, K. Concentrations, Fluxes, and Residence Time of PBDEs across the Tropical Atlantic Ocean. Environ. Sci. Technol., 2013, 47 (24), 13967-13975. https://doi.org/10.1021/es403494b.

[185] Fernandez, L. A.; Lao, W.; Maruya, K. A.; Burgess, R. M. Calculating the Diffusive Flux of Persistent Organic Pollutants between Sediments and the Water Column on the Palos Verdes Shelf Superfund Site Using Polymeric Passive Samplers. Environ. Sci. Technol., 2014, 48 (7), 3925-3934. https://doi.org/10.1021/es404475c.

[186] Koelmans, A. A.; Bakir, A.; Burton, G. A.; Janssen, C. R. Microplastic as a Vector for Chemicals in the Aquatic Environment: Critical Review and Model-Supported Reinterpretation of Empirical Studies. Environ. Sci. Technol., 2016, 50 (7), 3315-3326. https://doi.org/10.1021/acs.est.5b06069.

[187] Wang, J.; Bi, Y.; Pfister, G.; Henkelmann, B.; Zhu, K.; Schramm, K.-W. Determination of PAH, PCB, and OCP in Water from the Three Gorges Reservoir Accumulated by Semipermeable Membrane Devices (SPMD). Chemosphere, 2009, 75 (8), 1119-1127. https://doi.org/10.1016/j.chemosphere.2009.01.016.

[188] Wang, J.; Henkelmann, B.; Bi, Y.; Zhu, K.; Pfister, G.; Hu, W.; Temoka, C.; Westrich, B.; Schramm, K.-W. Temporal Variation and Spatial Distribution of PAH in Water of Three Gorges Reservoir during the Complete Impoundment Period. Environ. Sci. Pollut. Res., 2013, 20 (10), 7071-7079. https://doi.org/10.1007/s11356-0121427-6.

[189] Temoka, C.; Wang, J.; Bi, Y.; Deyerling, D.; Pfister, G.; Henkelmann, B.; Schramm, K.-W. Concentrations and Mass Fluxes Estimation of Organochlorine Pesticides in Three Gorges Reservoir with Virtual Organisms Using in Situ PRC-Based Sampling Rate. Chemosphere, 2016, 144, 1521-1529. https://doi.org/10.1016/j.chemosphere.2015.10.007.

[190] Alvarez, D.; Perkins, S.; Nilsen, E.; Morace, J. Spatial and Temporal Trends in Occurrence of Emerging and Legacy Contaminants in the Lower Columbia River 2008-2010. Sci. Total Environ., 2014, 484 (1), 322-330. https://doi.org/10.1016/j.scitotenv.2013.07.128.

[191] Abbasi, Y.; Mannaerts, C. M. Evaluating Organochlorine Pesticide Residues in the Aquatic Environment of the Lake Naivasha River Basin Using Passive Sampling Techniques. Environ. Monit. Assess., 2018, 190 (6). https://doi.org/10.1007/s10661-018-6713-4.

[192] Chepchirchir, B. S.; Paschke, A.; Schüürmann, G. Passive Sampling for Spatial and Temporal Monitoring of Organic Pollutants in Surface Water of a Rural-Urban River in Kenya. Sci. Total Environ., 2017, 601-602, 453460. https://doi.org/10.1016/j.scitotenv.2017.05.143.

[193] Naudé, Y.; Gorst-Allman, P.; Rohwer, E. A Cheap and Simple Passive Sampler Using Silicone Rubber for the Analysis of Surface Water by Gas Chromatography-Time of Flight Mass Spectrometry. Water SA, 2015, 41 (2), 182-188. https://doi.org/10.4314/wsa.v41i2.02.

[194] Moschet, C.; Vermeirssen, E. L. M.; Seiz, R.; Pfefferli, H.; Hollender, J. Picogram per Liter Detections of Pyrethroids and Organophosphates in Surface Waters Using Passive Sampling. Water Res., 2014, 66, 411-422. https://doi.org/10.1016/j.watres.2014.08.032.

[195] Prokeš, R.; Vrana, B.; Klánová, J. Levels and Distribution of Dissolved Hydrophobic Organic Contaminants in the Morava River in Zlín District, Czech Republic as Derived from Their Accumulation in Silicone Rubber Passive Samplers. Environ. Pollut., 2012, 166, 157-166. https://doi.org/10.1016/j.envpol.2012.02.022.

[196] Harman, C.; Grung, M.; Djedjibegovic, J.; Marjanovic, A.; Fjeld, E.; Braaten, H. F. V; Sober, M.; Larssen, T.; Ranneklev, S. B. The Organic Pollutant Status of Rivers in Bosnia and Herzegovina as Determined by a Combination of Active and Passive Sampling Methods. Environ. Monit. Assess., 2018, 190 (5). https://doi.org/10.1007/s10661-018-6667-6.

[197] Schopfer, A.; Estoppey, N.; Omlin, J.; Udrisard, R.; Esseiva, P.; De Alencastro, L. F. The Use of Passive Samplers to Reveal Industrial and Agricultural Pollution Trends in Swiss Rivers. Chimia (Aarau)., 2014, 68 (11), 778-782. https://doi.org/10.2533/chimia.2014.778.

[198] Anderson, K. A.; Seck, D.; Hobbie, K. A.; Traore, A. N.; McCartney, M. A.; Ndaye, A.; Forsberg, N. D.; Haigh, T. A.; Sower, G. J. Passive Sampling Devices Enable Capacity Building and Characterization of Bioavailable Pesticide along the Niger, Senegal and Bani Rivers of Africa. Philos. Trans. R. Soc. B Biol. Sci., 2014, 369 (1639). https://doi.org/10.1098/rstb.2013.0110.

[199] Moles, A.; Holland, L.; Andersson, O. Assessment of the Significance of Direct and Indirect Pollution Inputs to a Major Salmon-Producing River Using Polyethylene Membrane Devices. Environ. Toxicol. Chem., 2006, 25 (8), 2011-2017. https://doi.org/10.1897/05-654R.1. 
[200] Vrana, B.; Klučárová, V.; Benická, E.; Abou-Mrad, N.; Amdany, R.; Horáková, S.; Draxler, A.; Humer, F.; Gans, O. Passive Sampling: An Effective Method for Monitoring Seasonal and Spatial Variability of Dissolved Hydrophobic Organic Contaminants and Metals in the Danube River. Environ. Pollut., 2014, 184, 101-112. https://doi.org/10.1016/j.envpol.2013.08.018.

[201] Mueller, J. F.; Mortimer, M. R.; O’Brien, J.; Komarova, T.; Carter, S. A Cleaner River: Long Term Use of Semipermeable Membrane Devices Demonstrate That Concentrations of Selected Organochlorines and PAHs in the Brisbane River Estuary, Queensland Have Reduced Substantially over the Past Decade. Mar. Pollut. Bull., 2011, 63 (5-12), 73-76. https://doi.org/10.1016/j.marpolbul.2011.03.026.

[202] Polidoro, B. A.; Morra, M. J.; Ruepert, C.; Castillo, L. E. Pesticide Sequestration in Passive Samplers (SPMDs): Considerations for Deployment Time, Biofouling, and Stream Flow in a Tropical Watershed. J. Environ. Monit., 2009, 11 (10), 1866-1874. https://doi.org/10.1039/b904329b.

[203] Goodbred, S. L.; Bryant, W. L.; Rosen, M. R.; Alvarez, D.; Spencer, T. How Useful Are the "Other" Semipermeable Membrane Devices (SPMDs); the Mini-Unit (15.2 Cm Long)? Sci. Total Environ., 2009, 407 (13), 4149-4156. https://doi.org/10.1016/j.scitotenv.2009.02.037.

[204] Sower, G. J.; Anderson, K. A. Spatial and Temporal Variation of Freely Dissolved Polycyclic Aromatic Hydrocarbons in an Urban River Undergoing Superfund Remediation. Environ. Sci. Technol., 2008, 42 (24), 9065 9071. https://doi.org/10.1021/es801286z.

[205] Tusseau-Vuillemin, M.-H.; Gourlay, C.; Lorgeoux, C.; Mouchel, J.-M.; Buzier, R.; Gilbin, R.; Seidel, J.-L.; ElbazPoulichet, F. Dissolved and Bioavailable Contaminants in the Seine River Basin. Sci. Total Environ., 2007, 375 (13), 244-256. https://doi.org/10.1016/j.scitotenv.2006.12.018.

[206] McCarthy, K. Assessment of the Usefulness of Semipermeable Membrane Devices for Long-Term Watershed Monitoring in an Urban Slough System. Environ. Monit. Assess., 2006, 118 (1-3), 293-318. https://doi.org/10.1007/s10661-006-1502-x.

[207] Silva-Barni, M. F.; Smedes, F.; Fillmann, G.; Miglioranza, K. S. B. Passive Sampling of Pesticides and Polychlorinated Biphenyls along the Quequén Grande River Watershed, Argentina. Environ. Toxicol. Chem., 2019, 38 (2), 340-349. https://doi.org/10.1002/etc.4325.

[208] Goksøyr, A.; Tollefsen, K. E.; Grung, M.; Løken, K.; Lie, E.; Zenker, A.; Fent, K.; Schlabach, M.; Huber, S. Balsa Raft Crossing the Pacific Finds Low Contaminant Levels. Environ. Sci. Technol., 2009, 43 (13), 4783-4790. https://doi.org/10.1021/es900154h.

[209] Meire, R. O.; Khairy, M.; Targino, A. C.; Galvão, P. M. A.; Torres, J. P. M.; Malm, O.; Lohmann, R. Use of Passive Samplers to Detect Organochlorine Pesticides in Air and Water at Wetland Mountain Region Sites (S-SE Brazil). Chemosphere, 2016, 144, 2175-2182. https://doi.org/10.1016/j.chemosphere.2015.10.133.

[210] European Commission. Directive 2013/39/EU. Off. J. Eur. Union, 2013.

[211] Lohmann, R.; Muir, D.; Zeng, E. Y.; Bao, L.-J.; Allan, I. J.; Arinaitwe, K.; Booij, K.; Helm, P.; Kaserzon, S.; Mueller, J. F.; et al. Aquatic Global Passive Sampling (AQUA-GAPS) Revisited: First Steps toward a Network of Networks for Monitoring Organic Contaminants in the Aquatic Environment. Environ. Sci. Technol., 2017, 51 (3), 1060-1067. https://doi.org/10.1021/acs.est.6b05159.

[212] Redman, A. D.; Butler, J. D.; Letinski, D. J.; Di Toro, D. M.; Leon Paumen, M.; Parkerton, T. F. Technical Basis for Using Passive Sampling as a Biomimetic Extraction Procedure to Assess Bioavailability and Predict Toxicity of Petroleum Substances. Chemosphere, 2018, 199, 585-594. https://doi.org/10.1016/j.chemosphere.2018.02.024.

[213] Letinski, D.; Parkerton, T.; Redman, A.; Manning, R.; Bragin, G.; Febbo, E.; Palandro, D.; Nedwed, T. Use of Passive Samplers for Improving Oil Toxicity and Spill Effects Assessment. Mar. Pollut. Bull., 2014, 86 (1-2), 274282. https://doi.org/10.1016/j.marpolbul.2014.07.006.

[214] Viant, M. R.; Davis, J. E.; Duffy, C.; Engel, J.; Stenton, C.; Sebire, M.; Katsiadaki, I. Application of Passive Sampling to Characterise the Fish Exometabolome. Metabolites, 2017, 7 (1). https://doi.org/10.3390/metabo7010008.

[215] Brack, W.; Dulio, V.; Ågerstrand, M.; Allan, I.; Altenburger, R.; Brinkmann, M.; Bunke, D.; Burgess, R. M.; Cousins, I.; Escher, B. I.; et al. Towards the Review of the European Union Water Framework Management of Chemical Contamination in European Surface Water Resources. Science of the Total Environment. 2017. https://doi.org/10.1016/j.scitotenv.2016.10.104.

[216] Hamers, T.; Legradi, J.; Zwart, N.; Smedes, F.; de Weert, J.; van den Brandhof, E.-J.; van de Meent, D.; de Zwart, D. Time-Integrative Passive Sampling Combined with TOxicity Profiling (TIPTOP): An Effect-Based Strategy for Cost-Effective Chemical Water Quality Assessment. Environ. Toxicol. Pharmacol., 2018, 64, 48-59. https://doi.org/10.1016/j.etap.2018.09.005.

[217] Gilbert, D.; Witt, G.; Smedes, F.; Mayer, P. Polymers as Reference Partitioning Phase: Polymer Calibration for an Analytically Operational Approach to Quantify Multimedia Phase Partitioning. Anal. Chem., 2016, 88 (11), 58185826. https://doi.org/10.1021/acs.analchem.6b00393.

[218] Verhagen, R.; O’Malley, E.; Smedes, F.; Mueller, J. F.; Kaserzon, S. Calibration Parameters for the Passive Sampling of Organic UV Filters by Silicone; Diffusion Coefficients and Silicone-Water Partition Coefficients. Chemosphere, 2019, 731-737. https://doi.org/10.1016/j.chemosphere.2019.02.077.

[219] Narváez Valderrama, J. F.; Baek, K.; Molina, F. J.; Allan, I. J. Implications of Observed PBDE Diffusion Coefficients in Low Density Polyethylene and Silicone Rubber. Environ. Sci. Process. Impacts, 2016, 18 (1), 87 94. https://doi.org/10.1039/c5em00507h.

[220] Schøyen, M.; Allan, I. J.; Ruus, A.; Håvardstun, J.; Hjermann, D. Ø.; Beyer, J. Comparison of Caged and Native Blue Mussels (Mytilus Edulis Spp.) for Environmental Monitoring of PAH, PCB and Trace Metals. Mar. Environ. Res., 2017, 130, 221-232. https://doi.org/10.1016/j.marenvres.2017.07.025.

[221] Belles, A.; Franke, C.; Alary, C.; Aminot, Y.; Readman, J. W. Understanding and Predicting the Diffusivity of 
Organic Compounds in Polydimethylsiloxane Material for Passive Sampler Applications Using a Simple Quantitative Structure-Property Relationship Model. Environ. Toxicol. Chem., 2018, 37 (5), 1291-1300. https://doi.org/10.1002/etc.4101.

[222] Jooshani, S.; Asgarpour Khansary, M.; Marjani, A.; Shirazian, S.; Shang, J. Contaminant Uptake by Polymeric Passive Samplers: A Modeling Study with Experimental Validation. Chem. Eng. Res. Des., 2018, 129, 231-236. https://doi.org/10.1016/j.cherd.2017.11.019.

[223] Asgarpour Khansary, M.; Shirazian, S.; Asadollahzadeh, M. Polymer-Water Partition Coefficients in Polymeric Passive Samplers. Environ. Sci. Pollut. Res., 2017, 24 (3), 2627-2631. https://doi.org/10.1007/s11356-016-8029-7.

[224] Chang, W.-T.; Lee, C.-L.; Brimblecombe, P.; Fang, M.-D.; Chang, K.-T.; Liu, J. T. The Effects of Flow Rate and Temperature on SPMD Measurements of Bioavailable PAHs in Seawater. Mar. Pollut. Bull., 2015, 97 (1-2), 217223. https://doi.org/10.1016/j.marpolbul.2015.06.013.

[225] Jonker, M. T. O.; Van Der Heijden, S. A.; Kotte, M.; Smedes, F. Quantifying the Effects of Temperature and Salinity on Partitioning of Hydrophobic Organic Chemicals to Silicone Rubber Passive Samplers. Environ. Sci. Technol., 2015, 49 (11), 6791-6799. https://doi.org/10.1021/acs.est.5b00286.

[226] Estoppey, N.; Schopfer, A.; Omlin, J.; Esseiva, P.; Vermeirssen, E. L. M.; Delémont, O.; de Alencastro, L. F. Effect of Water Velocity on the Uptake of Polychlorinated Biphenyls (PCBs) by Silicone Rubber (SR) and Low-Density Polyethylene (LDPE) Passive Samplers: An Assessment of the Efficiency of Performance Reference Compounds (PRCs) in River-like Flow Condition. Sci. Total Environ., 2014, 499 (1), 319-326. https://doi.org/10.1016/j.scitotenv.2014.08.047.

[227] Booij, K.; Smedes, F.; Crum, S. Laboratory Performance Study for Passive Sampling of Nonpolar Chemicals in Water. Environ. Toxicol. Chem., 2017, 36 (5), 1156-1161. https://doi.org/10.1002/etc.3657.

[228] Kim, U.-J.; Jo, H.; Lee, I.-S.; Joo, G.-J.; Oh, J.-E. Investigation of Bioaccumulation and Biotransformation of Polybrominated Diphenyl Ethers, Hydroxylated and Methoxylated Derivatives in Varying Trophic Level Freshwater Fishes. Chemosphere, 2015, 137, 108-114. https://doi.org/10.1016/j.chemosphere.2015.05.104.

[229] Figueiredo, K.; Mäenpää, K.; Lyytikäinen, M.; Taskinen, J.; Leppänen, M. T. Assessing the Influence of Confounding Biological Factors When Estimating Bioaccumulation of PCBs with Passive Samplers in Aquatic Ecosystems. Sci. Total Environ., 2017, 601-602, 340-345. https://doi.org/10.1016/j.scitotenv.2017.05.140.

[230] Joyce, A. S.; Portis, L. M.; Parks, A. N.; Burgess, R. M. Evaluating the Relationship between Equilibrium Passive Sampler Uptake and Aquatic Organism Bioaccumulation. Environ. Sci. Technol., 2016, 50 (21), 11437-11451. https://doi.org/10.1021/acs.est.6b03273.

[231] Heltsley, R. M.; Cope, W. G.; Shea, D.; Bringolf, R. B.; Kwak, T. J.; Malindzak, E. G. Assessing Organic Contaminants in Fish: Comparison of a Nonlethal Tissue Sampling Technique to Mobile and Stationary Passive Sampling Devices. Environ. Sci. Technol., 2005, 39 (19), 7601-7608. https://doi.org/10.1021/es051037s.

[232] Smedes, F.; Bakker, D.; de Weert, J. The Use of Passive Sampling in WFD Monitoring. Deltares, 2010.

[233] EC. Guidance Document No. 32 on Biota Monitoring (The Implementation of EQSbiota) under the Water Framework Directive. Common Implementation Strategy for the Water Framework Directive (2000/60/EC).; 2014. https://doi.org/doi: 10.2779/833200.

[234] Bargar, T. A.; Whelan, K. R. T.; Alvarez, D.; Echols, K.; Peterman, P. H. Baseline Aquatic Contamination and Endocrine Status in a Resident Fish of Biscayne National Park. Mar. Pollut. Bull., 2017, 115 (1-2), 525-533. https://doi.org/10.1016/j.marpolbul.2016.11.044.

[235] Zhao, D.; Zhang, P.; Ge, L.; Zheng, G. J.; Wang, X.; Liu, W.; Yao, Z. The Legacy of Organochlorinated Pesticides (OCPs), Polycyclic Aromatic Hydrocarbons (PAHs) and Polychlorinated Biphenyls (PCBs) in Chinese Coastal Seawater Monitored by Semi-Permeable Membrane Devices (SPMDs). Mar. Pollut. Bull., 2018, 137, 222-230. https://doi.org/10.1016/j.marpolbul.2018.10.004.

[236] Marrucci, A.; Marras, B.; Campisi, S. S.; Schintu, M. Using SPMDs to Monitor the Seawater Concentrations of PAHs and PCBs in Marine Protected Areas (Western Mediterranean). Mar. Pollut. Bull., 2013, 75 (1-2), 69-75. https://doi.org/10.1016/j.marpolbul.2013.08.004.

[237] Shaw, M.; Furnas, M. J.; Fabricius, K.; Haynes, D.; Carter, S.; Eaglesham, G.; Mueller, J. F. Monitoring Pesticides in the Great Barrier Reef. Mar. Pollut. Bull., 2010, 60 (1), 113-122.

https://doi.org/10.1016/j.marpolbul.2009.08.026.

[238] Vetter, W.; Haase-Aschoff, P.; Rosenfelder, N.; Komarova, T.; Mueller, J. F. Determination of Halogenated Natural Products in Passive Samplers Deployed along the Great Barrier Reef, Queensland/Australia. Environ. Sci. Technol., 2009, 43 (16), 6131-6137. https://doi.org/10.1021/es900928m.

[239] Roach, A. C.; Muller, R.; Komarova, T.; Symons, R.; Stevenson, G. J.; Mueller, J. F. Using SPMDs to Monitor Water Column Concentrations of PCDDs, PCDFs and Dioxin-like PCBs in Port Jackson (Sydney Harbour), Australia. Chemosphere, 2009, 75 (9), 1243-1251. https://doi.org/10.1016/j.chemosphere.2009.01.071.

[240] Shaw, M.; Müller, J. F. Preliminary Evaluation of the Occurrence of Herbicides and PAHs in the Wet Tropics Region of the Great Barrier Reef, Australia, Using Passive Samplers. Mar. Pollut. Bull., 2005, 51 (8-12), 876-881. https://doi.org/10.1016/j.marpolbul.2005.04.015.

[241] Neziri, A.; Marku, E.; Nuro, A. Identification of Polychlorinated Biphenyls in Shkodra Lake Water Using Bottle Sampling and Passive Sampling Technology. Asian J. Chem., 2010, 22 (10), 7850-7856.

[242] Helm, P. A.; Howell, E. T.; Li, H.; L. Metcalfe, T.; M. Chomicki, K.; D. Metcalfe, C. Influence of Nearshore Dynamics on the Distribution of Organic Wastewater-Associated Chemicals in Lake Ontario Determined Using Passive Samplers. J. Great Lakes Res., 2012, 38 (SUPPL.4), 105-115. https://doi.org/10.1016/j.jglr.2012.01.005.

[243] Fox, J. T.; Adams, G.; Sharum, M.; Steelman, K. L. Passive Sampling of Bioavailable Organic Chemicals in Perry County, Missouri Cave Streams. Environ. Sci. Technol., 2010, 44 (23), 8835-8841. https://doi.org/10.1021/es1019367. 
[244] Levy, W.; Pandelova, M.; Henkelmann, B.; Bernhöft, S.; Fischer, N.; Antritter, F.; Schramm, K.-W. Persistent Organic Pollutants in Shallow Percolated Water of the Alps Karst System (Zugspitze Summit, Germany). Sci. Total Environ., 2017, 579, 1269-1281. https://doi.org/10.1016/j.scitotenv.2016.11.113.

[245] Pogorzelec, M.; Piekarska, K. Toxicity Assessment of Water at Different Stages of Treatment Using Microtox Assay. In 9th Conference on Interdisciplinary Problems in Environmental Protection and Engineering, EKO-DOK 2017; K., P., M., K., A., T.-Z., B., K., Eds.; EDP Sciences: Wroclaw University of Science and Technology, Faculty of Environmental Engineering, Wybrzeze Wyspiańskiego 27, Wrocław, 50-370, Poland, 2017; Vol. 17. https://doi.org/10.1051/e3sconf/20171700076.

[246] Wang, J.; Song, G.; Li, A.; Henkelmann, B.; Pfister, G.; Tong, A. Z.; Schramm, K.-W. Combined Chemical and Toxicological Long-Term Monitoring for AhR Agonists with SPMD-Based Virtual Organisms in Drinking Water Danjiangkou Reservoir, China. Chemosphere, 2014, 108, 306-313. https://doi.org/10.1016/j.chemosphere.2014.01.056.

[247] Kočí, V.; Ocelka, T.; Dragoun, D.; Vít, M.; Grabic, R.; Šváb, M. Concentration of Organochlorine Pollutants in Surface Waters of the Central European Biosphere Reserve Krivoklatsko. Environ. Sci. Pollut. Res., 2007, 14 (2), 94-101. https://doi.org/10.1065/espr2006.10.353.

[248] Lembcke, D.; Ansell, A.; McConnell, C.; Ginn, B. Use of Semipermeable Membrane Devices to Investigate the Impacts of DDT (Dichlorodiphenyltrichloroethane) in the Holland Marsh Environs of the Lake Simcoe Watershed (Ontario, Canada). J. Great Lakes Res., 2011, 37 (SUPPL. 3), 142-147. https://doi.org/10.1016/j.jglr.2011.01.002.

[249] Gillis, P. L.; Gagné, F.; Mcinnis, R.; Hooey, T. M.; Choy, E. S.; André, C.; Hoque, M. E.; Metcalfe, C. D. The Impact of Municipal Wastewater Effluent on Field-Deployed Freshwater Mussels in the Grand River (Ontario, Canada). Environ. Toxicol. Chem., 2014, 33 (1), 134-143. https://doi.org/10.1002/etc.2401.

[250] Jasinska, E. J.; Goss, G. G.; Gillis, P. L.; Van Der Kraak, G. J.; Matsumoto, J.; de Souza Machado, A. A.; Giacomin, M.; Moon, T. W.; Massarsky, A.; Gagné, F.; et al. Assessment of Biomarkers for Contaminants of Emerging Concern on Aquatic Organisms Downstream of a Municipal Wastewater Discharge. Sci. Total Environ., 2015, 530-531, 140-153. https://doi.org/10.1016/j.scitotenv.2015.05.080.

[251] Terzopoulou, E.; Voutsa, D. Study of Persistent Toxic Pollutants in a River Basin-Ecotoxicological Risk Assessment. Ecotoxicology, 2017, 26 (5), 625-638. https://doi.org/10.1007/s10646-017-1795-2.

[252] Zounkova, R.; Jalova, V.; Janisova, M.; Ocelka, T.; Jurcikova, J.; Halirova, J.; Giesy, J. P.; Hilscherova, K. In Situ Effects of Urban River Pollution on the Mudsnail Potamopyrgus Antipodarum as Part of an Integrated Assessment. Aquat. Toxicol., 2014, 150, 83-92. https://doi.org/10.1016/j.aquatox.2014.02.021.

[253] Jálová, V.; Jarošová, B.; Bláha, L.; Giesy, J. P.; Ocelka, T.; Grabic, R.; Jurčíková, J.; Vrana, B.; Hilscherová, K. Estrogen-, Androgen- and Aryl Hydrocarbon Receptor Mediated Activities in Passive and Composite Samples from Municipal Waste and Surface Waters. Environ. Int., 2013, 59, 372-383. https://doi.org/10.1016/j.envint.2013.06.024.

[254] Metcalfe, T. L.; Dillon, P. J.; Metcalfe, C. D. Detecting the Transport of Toxic Pesticides from Golf Courses into Watersheds in the Precambrian Shield Region of Ontario, Canada. Environ. Toxicol. Chem., 2008, 27 (4), 811-818. https://doi.org/10.1897/07-216.1.

[255] Ke, R.; Li, J.; Qiao, M.; Xu, Y.; Wang, Z. Using Semipermeable Membrane Devices, Bioassays, and Chemical Analysis for Evaluation of Bioavailable Polycyclic Aromatic Hydrocarbons in Water. Arch. Environ. Contam. Toxicol., 2007, 53 (3), 313-320. https://doi.org/10.1007/s00244-006-0158-4.

[256] Pickford, D. B.; Jones, A.; Velez-Pelez, A.; Iguchi, T.; Mitsui, N.; Tooi, O. Screening Breeding Sites of the Common Toad (Bufo Bufo) in England and Wales for Evidence of Endocrine Disrupting Activity. Ecotoxicol. Environ. Saf., 2015, 117, 7-19. https://doi.org/10.1016/j.ecoenv.2015.03.006.

[257] Crootof, A.; Mullabaev, N.; Saito, L.; Atwell, L.; Rosen, M. R.; Bekchonova, M.; Ginatullina, E.; Scott, J.; Chandra, S.; Nishonov, B.; et al. Hydroecological Condition and Potential for Aquaculture in Lakes of the Arid Region of Khorezm, Uzbekistan. J. Arid Environ., 2015, 117, 37-46. https://doi.org/10.1016/j.jaridenv.2015.02.012.

[258] Kočí, V.; Ocelka, T.; Grabic, R. Background Level of Pops in Ground Water Assessed on Chemical and Toxicity Analysis of Exposed Semipermeable Membrane Devices. Air, Soil Water Res., 2009, 2, 1-14.

[259] Spearow, J. L.; Kota, R. S.; Ostrach, D. J. Environmental Contaminant Effects on Juvenile Striped Bass in the San Francisco Estuary, California, USA. Environ. Toxicol. Chem., 2011, 30 (2), 393-402. https://doi.org/10.1002/etc.386.

[260] Chẹć, E.; Podgórska, B.; Wȩgrzyn, G. Comparison of the Use of Mussels and Semipermeable Membrane Devices for Monitoring and Assessment of Accumulation of Mutagenic Pollutants in Marine Environment in Combination with a Novel Microbiological Mutagenicity Assay. Environ. Monit. Assess., 2008, 140 (1-3), 83-90. https://doi.org/10.1007/s10661-007-9849-1.

[261] Li, A. J.; Sang, Z.; Chow, C.-H.; Law, J. C.-F.; Guo, Y.; Leung, K. S.-Y. Environmental Behavior of 12 UV Filters and Photocatalytic Profile of Ethyl-4-Aminobenzoate. J. Hazard. Mater., 2017, 337, 115-125. https://doi.org/10.1016/j.jhazmat.2017.04.067.

[262] Gonçalves, A. D.; Robaina, N. F.; dos Reis, L. G. T.; Cassella, R. J. Optimization of a Methodology for Sampling of Five Polycyclic Aromatic Hydrocarbons in Saline Waters Using a Semipermeable Membrane Device. Microchem. J., 2015, 122, 96-101. https://doi.org/10.1016/j.microc.2015.04.008.

[263] Wang, P.; Hou, S.; Sun, S. Effect of Dissolved Organic Matter and Water Chemistry on the Uptake of Several Organic Contaminants by Semipermeable Membrane Device (SPMD). Fresenius Environ. Bull., 2012, 21 (9), 2544-2550.

[264] Prokeš, R.; Vrana, B.; Klánová, J.; Kupec, J. Calibration of Three Passive Samplers of Hydrophobic Organic Compounds in Water: Assessment of Critical Issues in Experimental Design Data Interpretation and Field 
Application. Fresenius Environ. Bull., 2010, 19 (12), 2812-2822.

[265] Harman, C.; Tollefsen, K.-E.; Bøyum, O.; Thomas, K.; Grung, M. Uptake Rates of Alkylphenols, PAHs and Carbazoles in Semipermeable Membrane Devices (SPMDs) and Polar Organic Chemical Integrative Samplers (POCIS). Chemosphere, 2008, 72 (10), 1510-1516. https://doi.org/10.1016/j.chemosphere.2008.04.091.

[266] Liu, F.; Zheng, H.-T.; Li, L. Simulation experiment on the sampling by triolein-SPMD for underground water. Kuangwu Yanshi, 2005, 25 (1), 113-116.

[267] Temoka, P.; Pfister, G.; Henkelmann, B.; Schramm, K.-W. Adapting Current Model with Field Data of Related Performance Reference Compounds in Passive Samplers to Accurately Monitor Hydrophobic Organic Compounds in Aqueous Media. Environ. Monit. Assess., 2017, 189 (11). https://doi.org/10.1007/s10661-017-6252-4.

[268] Forsberg, N. D.; Smith, B. W.; Sower, G. J.; Anderson, K. A. Predicting Polycyclic Aromatic Hydrocarbon Concentrations in Resident Aquatic Organisms Using Passive Samplers and Partial Least-Squares Calibration. Environ. Sci. Technol., 2014, 48 (11), 6291-6299. https://doi.org/10.1021/es5000534.

[269] Allan, I. J.; Nilsson, H. C.; Tjensvoll, I.; Bradshaw, C.; Næs, K. Mobile Passive Samplers: Concept for a Novel Mode of Exposure. Environ. Pollut., 2011, 159 (10), 2393-2397. https://doi.org/10.1016/j.envpol.2011.06.039.

[270] Zhao, W.; Han, M.; Dai, S.; Xu, J.; Wang, P. Ionic Liquid-Containing Semipermeable Membrane Devices for Monitoring the Polycyclic Aromatic Hydrocarbons in Water. Chemosphere, 2006, 62 (10), 1623-1629. https://doi.org/10.1016/j.chemosphere.2005.06.041.

[271] Ke, R.; Xu, Y.; Wang, Z.; Khan, S. U. Estimation of the Uptake Rate Constants for Polycyclic Aromatic Hydrocarbons Accumulated by Semipermeable Membrane Devices and Triolein-Embedded Cellulose Acetate Membranes. Environ. Sci. Technol., 2006, 40 (12), 3906-3911. https://doi.org/10.1021/es060493t.

[272] Liao, L. B.; Xiao, X. M. Accumulation of Organochlorine Pesticides by Semipermeable Membrane Devices Using Composite Complex. Chemosphere, 2006, 64 (9), 1592-1600. https://doi.org/10.1016/j.chemosphere.2005.11.014.

[273] Booij, K.; Tucca, F. Passive Samplers of Hydrophobic Organic Chemicals Reach Equilibrium Faster in the Laboratory than in the Field. Mar. Pollut. Bull., 2015, 98 (1-2), 365-367. https://doi.org/10.1016/j.marpolbul.2015.07.007.

[274] Šetková, L.; Hajšlová, J.; Bergqvist, P.-A.; Kocourek, V.; Kazda, R.; Suchan, P. Fast Isolation of Hydrophobic Organic Environmental Contaminants from Exposed Semipermeable Membrane Devices (SPMDs) Prior to GC Analysis. J. Chromatogr. A, 2005, 1092 (2), 170-181. https://doi.org/10.1016/j.chroma.2005.07.059.

[275] Fontenelle, F. R.; Taniguchi, S.; da Silva, J.; Lourenço, R. A. Environmental Quality Survey of an Industrialized Estuary and an Atlantic Forest Biosphere Reserve through a Comparative Appraisal of Organic Pollutants. Environ. Pollut., 2019, 248, 339-348. https://doi.org/10.1016/j.envpol.2019.02.023.

[276] Chiu, J. M. Y.; Po, B. H. K.; Degger, N.; Tse, A.; Liu, W.; Zheng, G.; Zhao, D.-M.; Xu, D.; Richardson, B.; Wu, R S. S. Contamination and Risk Implications of Endocrine Disrupting Chemicals along the Coastline of China: A Systematic Study Using Mussels and Semipermeable Membrane Devices. Sci. Total Environ., 2018, 624, 1298 1307. https://doi.org/10.1016/j.scitotenv.2017.12.214.

[277] Okay, O. S.; Karacık, B.; Güngördü, A.; Yılmaz, A.; Koyunbaba, N. C.; Yakan, S. D.; Henkelmann, B.; Schramm, K.-W.; Ozmen, M. Monitoring of Organic Pollutants in Marine Environment by Semipermeable Membrane Devices and Mussels: Accumulation and Biochemical Responses. Environ. Sci. Pollut. Res., 2017, 24 (23), 19114-19125. https://doi.org/10.1007/s11356-017-9594-0.

[278] Bustamante, J.; Arana, G.; de Diego, A.; Madariaga, J. M. The Use of SPMDs and Implanted Oysters for Monitoring Pahs and PCBs in an Aquatic Environment in the Estuary of Urdaibai (Western Pyrenees). Environ. Eng. Manag. J., 2012, 11 (9), 1707-1714.

[279] Degger, N.; Wepener, V.; Richardson, B. J.; Wu, R. S. S. Brown Mussels (Perna Perna) and Semi-Permeable Membrane Devices (SPMDs) as Indicators of Organic Pollutants in the South African Marine Environment. Mar. Pollut. Bull., 2011, 63 (5-12), 91-97. https://doi.org/10.1016/j.marpolbul.2011.04.024.

[280] Berge, J. A.; Hylland, K.; Schlabach, M.; Ruus, A. Accumulation of Polychlorinated Dibenzo-p-Dioxins and Furans in Atlantic Cod (Gadus Morhua)Cage Experiments in a Norwegian Fjord. J. Toxicol. Environ. Heal. - Part A Curr. Issues, 2011, 74 (7-9), 455-465. https://doi.org/10.1080/15287394.2011.550556.

[281] Harman, C.; Holth, T. F.; Hylland, K.; Thomas, K.; Grung, M. Relationship between Polycyclic Aromatic Hydrocarbon (PAH) Accumulation in Semipermeable Membrane Devices and PAH Bile Metabolite Levels in Atlantic Cod (Gadus Morhua). J. Toxicol. Environ. Heal. - Part A Curr. Issues, 2009, 72 (3-4), 234-243. https://doi.org/10.1080/15287390802539160.

[282] Gourlay, C.; Miège, C.; Noir, A.; Ravelet, C.; Garric, J.; Mouchel, J.-M. How Accurately Do Semi-Permeable Membrane Devices Measure the Bioavailability of Polycyclic Aromatic Hydrocarbons to Daphnia Magna? Chemosphere, 2005, 61 (11), 1734-1739. https://doi.org/10.1016/j.chemosphere.2005.04.039.

[283] Ke, R.-H.; Qiao, M.; Xu, Y.-P.; Huang, S.-B.; Wang, Z.-J. Comparison between biomimetic sampling technique using semipermeable membrane device and bioconcentration in caged fish for polycyclic aromatic hydrocarbons. Huanjing Kexue/Environmental Sci., 2006, 27 (7), 1410-1414.

[284] Ke, R.; Xu, Y.; Huang, S.; Wang, Z.; Huckins, J. N. Comparison of the Uptake of Polycyclic Aromatic Hydrocarbons and Organochlorine Pesticides by Semipermeable Membrane Devices and Caged Fish (Carassius Carassius) in Taihu Lake, China. Environ. Toxicol. Chem., 2007, 26 (6), 1258-1264. https://doi.org/10.1897/06454R1.1.

[285] Leiker, T. J.; Abney, S. R.; Goodbred, S. L.; Rosen, M. R. Identification of Methyl Triclosan and Halogenated Analogues in Male Common Carp (Cyprinus Carpio) from Las Vegas Bay and Semipermeable Membrane Devices from Las Vegas Wash, Nevada. Sci. Total Environ., 2009, 407 (6), 2102-2114. https://doi.org/10.1016/j.scitotenv.2008.11.009.

[286] Wang, J.; Liang, W.; Henkelmann, B.; Pfister, G.; Schramm, K.-W. Organochlorine Pesticides Accumulated by 
SPMD-Based Virtual Organisms and Feral Fish in Three Gorges Reservoir, China. Environ. Pollut., 2015, 202, 160-167. https://doi.org/10.1016/j.envpol.2015.03.031.

[287] Richardson, B. J.; Tse, E. S.-C.; De Luca-Abbott, S. B.; Martin, M.; Lam, P. K. S. Uptake and Depuration of PAHs and Chlorinated Pesticides by Semi-Permeable Membrane Devices (SPMDs) and Green-Lipped Mussels (Perna Viridis). Mar. Pollut. Bull., 2005, 51 (8-12), 975-993. https://doi.org/10.1016/j.marpolbul.2005.04.028.

[288] Hernando, M. D.; Martínez-Bueno, M. J.; Fernández-Alba, A. R. Seawater Quality Control of Microcontaminants in Fish Farm Cage Systems: Application of Passive Sampling Devices. Bol. - Inst. Esp. Oceanogr., 2005, 21 (1-4), $37-46$.

[289] Monteyne, E.; Roose, P.; Janssen, C. R. Application of a Silicone Rubber Passive Sampling Technique for Monitoring PAHs and PCBs at Three Belgian Coastal Harbours. Chemosphere, 2013, 91 (3), 390-398. https://doi.org/10.1016/j.chemosphere.2012.11.074.

[290] van der Oost, R.; Sileno, G.; Janse, T.; Nguyen, M. T.; Besselink, H.; Brouwer, A. SIMONI (Smart Integrated Monitoring) as a Novel Bioanalytical Strategy for Water Quality Assessment: Part II-Field Feasibility Survey. Environ. Toxicol. Chem., 2017, 36 (9), 2400-2416. https://doi.org/10.1002/etc.3837.

[291] Liscio, C.; Abdul-Sada, A.; Al-Salhi, R.; Ramsey, M. H.; Hill, E. M. Methodology for Profiling Anti-Androgen Mixtures in River Water Using Multiple Passive Samplers and Bioassay-Directed Analyses. Water Res., 2014, 57, 258-269. https://doi.org/10.1016/j.watres.2014.03.039.

[292] Emelogu, E. S.; Seiler, T.-B.; Pollard, P.; Robinson, C. D.; Webster, L.; McKenzie, C.; Heger, S.; Hollert, H.; Bresnan, E.; Best, J.; et al. Evaluations of Combined Zebrafish (Danio Rerio) Embryo and Marine Phytoplankton (Diacronema Lutheri) Toxicity of Dissolved Organic Contaminants in the Ythan Catchment, Scotland, UK. Environ. Sci. Pollut. Res., 2014, 21 (8), 5537-5546. https://doi.org/10.1007/s11356-013-2488-x.

[293] Long, M.; Strand, J.; Lassen, P.; Krüger, T.; Dahllöf, I.; Bossi, R.; Larsen, M. M.; Wiberg-Larsen, P.; BonefeldJørgensen, E. C. Endocrine-Disrupting Effects of Compounds in Danish Streams. Arch. Environ. Contam. Toxicol., 2014, 66 (1), 1-18. https://doi.org/10.1007/s00244-013-9959-4.

[294] Emelogu, E. S.; Pollard, P.; Robinson, C. D.; Smedes, F.; Webster, L.; Oliver, I. W.; McKenzie, C.; Seiler, T. B.; Hollert, H.; Moffat, C. F. Investigating the Significance of Dissolved Organic Contaminants in Aquatic Environments: Coupling Passive Sampling with in Vitro Bioassays. Chemosphere, 2013, 90 (2), 210-219. https://doi.org/10.1016/j.chemosphere.2012.06.041.

[295] Schäfer, R. B.; Hearn, L.; Kefford, B. J.; Mueller, J. F.; Nugegoda, D. Using Silicone Passive Samplers to Detect Polycyclic Aromatic Hydrocarbons from Wildfires in Streams and Potential Acute Effects for Invertebrate Communities. Water Res., 2010, 44 (15), 4590-4600. https://doi.org/10.1016/j.watres.2010.05.044.

[296] Booij, P.; Vethaak, A. D.; Leonards, P. E. G.; Sjollema, S. B.; Kool, J.; De Voogt, P.; Lamoree, M. H. Identification of Photosynthesis Inhibitors of Pelagic Marine Algae Using 96-Well Plate Microfractionation for Enhanced Throughput in Effect-Directed Analysis. Environ. Sci. Technol., 2014, 48 (14), 8003-8011. https://doi.org/10.1021/es405428t.

[297] Booij, P.; Sjollema, S. B.; Leonards, P. E. G.; de Voogt, P.; Stroomberg, G. J.; Vethaak, A. D.; Lamoree, M. H. Extraction Tools for Identification of Chemical Contaminants in Estuarine and Coastal Waters to Determine Toxic Pressure on Primary Producers. Chemosphere, 2013, 93 (1), 107-114. https://doi.org/10.1016/j.chemosphere.2013.04.095.

[298] Bi, H.; Rissik, D.; MacOva, M.; Hearn, L.; Mueller, J. F.; Escher, B. Recovery of a Freshwater Wetland from Chemical Contamination after an Oil Spill. J. Environ. Monit., 2011, 13 (3), 713-720. https://doi.org/10.1039/c0em00406e.

[299] Hale, S. E.; Škulcová, L.; Pípal, M.; Cornelissen, G.; Oen, A. M. P.; Eek, E.; Bielská, L. Monitoring Wastewater Discharge from the Oil and Gas Industry Using Passive Sampling and Danio Rerio Bioassay as Complimentary Tools. Chemosphere, 2019, 404-412. https://doi.org/10.1016/j.chemosphere.2018.10.162.

[300] Allan, I. J.; Harman, C.; Kringstad, A.; Bratsberg, E. Effect of Sampler Material on the Uptake of PAHs into Passive Sampling Devices. Chemosphere, 2010, 79 (4), 470-475.

https://doi.org/10.1016/j.chemosphere.2010.01.021.

[301] Kibbey, T. C. G.; Chen, L.; Sabatini, D. A.; Mills, M. A.; Nietch, C. Model Stream Channel Testing of a UVTransparent Polymer-Based Passive Sampler for Ultra-Low-Cost Water Screening Applications. Chemosphere, 2010, 80 (8), 908-913. https://doi.org/10.1016/j.chemosphere.2010.06.035.

[302] Nam, G.-U.; Bonifacio, R. G.; Kwon, J.-H.; Hong, Y. Kinetics and Equilibrium Partitioning of Dissolved BTEX in PDMS and POM Sheets. Environ. Sci. Pollut. Res., 2016, 23 (18), 18901-18910. https://doi.org/10.1007/s11356016-7098-y.

[303] Zendong, Z.; Herrenknecht, C.; Abadie, E.; Brissard, C.; Tixier, C.; Mondeguer, F.; Séchet, V.; Amzil, Z.; Hess, P. Extended Evaluation of Polymeric and Lipophilic Sorbents for Passive Sampling of Marine Toxins. Toxicon, 2014, 91, 57-68. https://doi.org/10.1016/j.toxicon.2014.03.010.

[304] Kibbey, T. C. G.; Chen, L.; Singhaputtangkul, N.; Sabatini, D. A. A UV-Transparent Passive Concentrator/Spectrum Deconvolution Method for Simultaneous Detection of Endocrine Disrupting Chemicals (EDCs) and Related Contaminants in Natural Waters. Chemosphere, 2009, 76 (9), 1249-1257. https://doi.org/10.1016/j.chemosphere.2009.05.016.

[305] Shea, D.; Tester, P.; Cohen, J.; Kibler, S.; Varnam, S. Accumulation of Brevetoxins by Passive Sampling Devices. African J. Mar. Sci., 2006, 28 (2), 379-381. https://doi.org/10.2989/18142320609504182.

[306] Brockmeyer, B.; Kraus, U. R.; Theobald, N. Accelerated Solvent Extraction (ASE) for Purification and Extraction of Silicone Passive Samplers Used for the Monitoring of Organic Pollutants. Environ. Sci. Pollut. Res., 2015, 22 (24), 19887-19895. https://doi.org/10.1007/s11356-015-5192-1.

[307] Shahpoury, P.; Hageman, K. J. Pressurized Liquid Extraction of Polycyclic Aromatic Hydrocarbons from Silicone 
Rubber Passive Samplers. J. Chromatogr. A, 2013, 1314, 1-6. https://doi.org/10.1016/j.chroma.2013.08.092.

[308] Burgess, R. M.; Lohmann, R.; Schubauer-Berigan, J. P.; Reitsma, P.; Perron, M. M.; Lefkovitz, L.; Cantwell, M. G. Application of Passive Sampling for Measuring Dissolved Concentrations of Organic Contaminants in the Water Column at Three Marine Superfund Sites. Environ. Toxicol. Chem., 2015, 34 (8), 1720-1733. https://doi.org/10.1002/etc.2995.

[309] Mäenpää, K.; Leppänen, M. T.; Figueiredo, K.; Mayer, P.; Gilbert, D.; Jahnke, A.; Gil-Allué, C.; Akkanen, J.; Nybom, I.; Herve, S. Fate of Polychlorinated Biphenyls in a Contaminated Lake Ecosystem: Combining Equilibrium Passive Sampling of Sediment and Water with Total Concentration Measurements of Biota. Environ. Toxicol. Chem., 2015, 34 (11), 2463-2474. https://doi.org/10.1002/etc.3099.

[310] Shahpoury, P.; Hageman, K. J.; Matthaei, C. D.; Alumbaugh, R. E.; Cook, M. E. Increased Concentrations of Polycyclic Aromatic Hydrocarbons in Alpine Streams during Annual Snowmelt: Investigating Effects of Sampling Method, Site Characteristics, and Meteorology. Environ. Sci. Technol., 2014, 48 (19), 11294-11301. https://doi.org/10.1021/es502999e.

[311] Apostolopoulou, M.-V.; Monteyne, E.; Krikonis, K.; Pavlopoulos, K.; Roose, P.; Dehairs, F. Monitoring Polycyclic Aromatic Hydrocarbons in the Northeast Aegean Sea Using Posidonia Oceanica Seagrass and Synthetic Passive Samplers. Mar. Pollut. Bull., 2014, 87 (1), 338-344. https://doi.org/10.1016/j.marpolbul.2014.07.051.

[312] Qin, Z.; Mok, S.; Ouyang, G.; Dixon, D. G.; Pawliszyn, J. Partitioning and Accumulation Rates of Polycyclic Aromatic Hydrocarbons into Polydimethylsiloxane Thin Films and Black Worms from Aqueous Samples. Anal. Chim. Acta, 2010, 667 (1-2), 71-76. https://doi.org/10.1016/j.aca.2010.04.003.

[313] McDonough, C. A.; Khairy, M. A.; Muir, D. C. G.; Lohmann, R. Significance of Population Centers as Sources of Gaseous and Dissolved PAHs in the Lower Great Lakes. Environ. Sci. Technol., 2014, 48 (14), 7789-7797. https://doi.org/10.1021/es501074r.

[314] McDonough, C. A.; De Silva, A. O.; Sun, C.; Cabrerizo, A.; Adelman, D.; Soltwedel, T.; Bauerfeind, E.; Muir, D C. G.; Lohmann, R. Dissolved Organophosphate Esters and Polybrominated Diphenyl Ethers in Remote Marine Environments: Arctic Surface Water Distributions and Net Transport through Fram Strait. Environ. Sci. Technol., 2018, 52 (11), 6208-6216. https://doi.org/10.1021/acs.est.8b01127.

[315] Duncan, D. L.; Carls, M. G.; Rice, S. D.; Stekoll, M. S. The Toxicity of Creosote-Treated Wood to Pacific Herring Embryos and Characterization of Polycyclic Aromatic Hydrocarbons near Creosoted Pilings in Juneau, Alaska. Environ. Toxicol. Chem., 2017, 36 (5), 1261-1269. https://doi.org/10.1002/etc.3653.

[316] Vincent-Hubert, F.; Uher, E.; Di Giorgio, C.; Michel, C.; De Meo, M.; Gourlay-France, C. Use of Low Density Polyethylene Membranes for Assessment of Genotoxicity of PAHs in the Seine River. Ecotoxicology, 2017, 26 (2), 165-172. https://doi.org/10.1007/s10646-016-1751-6.

[317] Borrelli, R.; Tcaciuc, A. P.; Verginelli, I.; Baciocchi, R.; Guzzella, L.; Cesti, P.; Zaninetta, L.; Gschwend, P. M. Performance of Passive Sampling with Low-Density Polyethylene Membranes for the Estimation of Freely Dissolved DDx Concentrations in Lake Environments. Chemosphere, 2018, 200, 227-236. https://doi.org/10.1016/j.chemosphere.2018.02.077.

[318] Perron, M. M.; Burgess, R. M.; Cantwell, M. G.; Fernandez, L. A. Evaluating Cost When Selecting Performance Reference Compounds for the Environmental Deployment of Polyethylene Passive Samplers. Integr. Environ. Assess. Manag., 2015, 11 (2), 256-265. https://doi.org/10.1002/ieam.1582.

[319] O’Connell, S. G.; McCartney, M. A.; Paulik, L. B.; Allan, S. E.; Tidwell, L. G.; Wilson, G.; Anderson, K. A. Improvements in Pollutant Monitoring: Optimizing Silicone for Co-Deployment with Polyethylene Passive Sampling Devices. Environ. Pollut., 2014, 193, 71-78. https://doi.org/10.1016/j.envpol.2014.06.019.

[320] Bao, L.-J.; Xu, S.-P.; Liang, Y.; Zeng, E. Y. Development of a Low-Density Polyethylene-Containing Passive Sampler for Measuring Dissolved Hydrophobic Organic Compounds in Open Waters. Environ. Toxicol. Chem., 2012, 31 (5), 1012-1018. https://doi.org/10.1002/etc.1788.

[321] Joyce, A. S.; Burgess, R. M. Using Performance Reference Compounds to Compare Mass Transfer Calibration Methodologies in Passive Samplers Deployed in the Water Column. Environ. Toxicol. Chem., 2018. https://doi.org/10.1002/etc.4167.

[322] Lao, W.; Maruya, K. A.; Tsukada, D. An Exponential Model Based New Approach for Correcting Aqueous Concentrations of Hydrophobic Organic Chemicals Measured by Polyethylene Passive Samplers. Sci. Total Environ., 2019, 646, 11-18. https://doi.org/10.1016/j.scitotenv.2018.07.192.

[323] Zhu, T.-Y.; Jiang, Y.; Wu, J.; Chen, H.-M.; He, C.-D. Development of QSAR model for predicting diffusion coefficients of PCBs and PAHs in LDPE . Zhongguo Huanjing Kexue/China Environ. Sci., 2018, 38 (12), 46314635 .

[324] Xue, J.; Liao, C.; Wang, J.; Cryder, Z.; Xu, T.; Liu, F.; Gan, J. Development of Passive Samplers for in Situ Measurement of Pyrethroid Insecticides in Surface Water. Environ. Pollut., 2017, 224, 516-523. https://doi.org/10.1016/j.envpol.2017.02.034.

[325] Tcaciuc, A. P.; Apell, J. N.; Gschwend, P. M. Modeling the Transport of Organic Chemicals between Polyethylene Passive Samplers and Water in Finite and Infinite Bath Conditions. Environ. Toxicol. Chem., 2015, 34 (12), 2739 2749. https://doi.org/10.1002/etc.3128.

[326] Bruemmer, J.; Falcon, R.; Greenwood, R.; Mills, G. A.; Hastie, C.; Sparham, C.; van Egmond, R. Measurement of Cyclic Volatile Methylsiloxanes in the Aquatic Environment Using Low-Density Polyethylene Passive Sampling Devices Using an in-Field Calibration Study - Challenges and Guidance. Chemosphere, 2015, 122, 38-44. https://doi.org/10.1016/j.chemosphere.2014.10.069.

[327] Fan, J.; Zhou, Y.-M. The establishment and application of predict model for passive sampling technique with LDPE membranes. Zhongguo Huanjing Kexue/China Environ. Sci., 2015, 35 (11), 3340-3345.

[328] Reitsma, P. J.; Adelman, D.; Lohmann, R. Challenges of Using Polyethylene Passive Samplers to Determine 
Dissolved Concentrations of Parent and Alkylated PAHs under Cold and Saline Conditions. Environ. Sci. Technol., 2013, 47 (18), 10429-10437. https://doi.org/10.1021/es402528q.

[329] Fries, E.; Zarfl, C. Sorption of Polycyclic Aromatic Hydrocarbons (PAHs) to Low and High Density Polyethylene (PE). Environ. Sci. Pollut. Res., 2012, 19 (4), 1296-1304. https://doi.org/10.1007/s11356-011-0655-5.

[330] Friedman, C. L.; Lohmann, R. Comparing Sediment Equilibrium Partitioning and Passive Sampling Techniques to Estimate Benthic Biota PCDD/F Concentrations in Newark Bay, New Jersey (U.S.A.). Environ. Pollut., 2014, 186, 172-179. https://doi.org/10.1016/j.envpol.2013.12.002.

[331] Alvarez, D. A.; Maruya, K. A.; Dodder, N. G.; Lao, W.; Furlong, E. T.; Smalling, K. L. Occurrence of Contaminants of Emerging Concern along the California Coast (2009-10) Using Passive Sampling Devices. Mar. Pollut. Bull., 2014, 81 (2), 347-354. https://doi.org/10.1016/j.marpolbul.2013.04.022.

[332] Joyce, A. S.; Pirogovsky, M. S.; Adams, R. G.; Lao, W.; Tsukada, D.; Cash, C. L.; Haw, J. F.; Maruya, K. A. Using Performance Reference Compound-Corrected Polyethylene Passive Samplers and Caged Bivalves to Measure Hydrophobic Contaminants of Concern in Urban Coastal Seawaters. Chemosphere, 2015, 127, 10-17. https://doi.org/10.1016/j.chemosphere.2014.12.067.

[333] Stewart, M.; Cameron, M.; McMurtry, M.; Sander, S. G.; Benedict, B.; Graham, L.; Hosie, M.; Green, T. Development of Passive Sampling Devices for Bioavailable Contaminants of Current and Emerging Concern: Waitemata Harbour Case Study. New Zeal. J. Mar. Freshw. Res., 2016, 50 (4), 526-548. https://doi.org/10.1080/00288330.2016.1181662.

[334] Oziolor, E. M.; Apell, J. N.; Winfield, Z. C.; Back, J. A.; Usenko, S.; Matson, C. W. Polychlorinated Biphenyl (PCB) Contamination in Galveston Bay, Texas: Comparing Concentrations and Profiles in Sediments, Passive Samplers, and Fish. Environ. Pollut., 2018, 236, 609-618. https://doi.org/10.1016/j.envpol.2018.01.086.

[335] Paulik, L. B.; Smith, B. W.; Bergmann, A. J.; Sower, G. J.; Forsberg, N. D.; Teeguarden, J. G.; Anderson, K. A. Passive Samplers Accurately Predict PAH Levels in Resident Crayfish. Sci. Total Environ., 2016, 544, 782-791. https://doi.org/10.1016/j.scitotenv.2015.11.142.

[336] Allinson, G.; Shiraishi, F.; Kamata, R.; Allinson, M. Combining Passive Sampling with Recombinant ReceptorReporter Gene Bioassays to Assess the Receptor Activity of Victorian Rivers. Bull. Environ. Contam. Toxicol., 2015, 95 (6), 758-763. https://doi.org/10.1007/s00128-015-1577-6.

[337] Ahkola, H.; Herve, S.; Knuutinen, J. Study of Different Chemcatcher Configurations in the Monitoring of Nonylphenol Ethoxylates and Nonylphenol in Aquatic Environment. Environ. Sci. Pollut. Res., 2014, 21 (15), 9182-9192. https://doi.org/10.1007/s11356-014-2828-5.

[338] El-Shenawy, N. S.; Nabil, Z. I.; Abdel-Nabi, I. M.; Greenwood, R. Comparing the Passive and Active Sampling Devices with Biomonitoring of Pollutants in Langstone and Portsmouth Harbour, UK. J. Environ. Sci. Technol., 2010, 3 (1), 1-17. https://doi.org/10.3923/jest.2010.1.17.

[339] El-Shenawy, N. S.; Greenwood, R.; Abdel-Nabi, I. M.; Nabil, Z. I. Comparing the Passive Sampler and Biomonitoring of Organic Pollutants in Water: A Laboratory Study. Ocean Sci. J., 2009, 44 (2), 69-77. https://doi.org/10.1007/s12601-009-0008-1.

[340] Lang, S.-C.; Mayer, P.; Hursthouse, A.; Kötke, D.; Hand, I.; Schulz-Bull, D.; Witt, G. Assessing PCB Pollution in the Baltic Sea - An Equilibrium Partitioning Based Study. Chemosphere, 2018, 191, 886-894. https://doi.org/10.1016/j.chemosphere.2017.10.073.

[341] Jonker, M. T. O. Determining Octanol-Water Partition Coefficients for Extremely Hydrophobic Chemicals by Combining "Slow Stirring" and Solid-Phase Microextraction. Environ. Toxicol. Chem., 2016, 35 (6), 1371-1377. https://doi.org/10.1002/etc.3300.

[342] Ouyang, G.; Cui, S.; Qin, Z.; Pawliszyn, J. One-Calibrant Kinetic Calibration for on-Site Water Sampling with Solid-Phase Microextraction. Anal. Chem., 2009, 81 (14), 5629-5636. https://doi.org/10.1021/ac900315w.

[343] Zhao, W.; Ouyang, G.; Alaee, M.; Pawliszyn, J. On-Rod Standardization Technique for Time-Weighted Average Water Sampling with a Polydimethylsiloxane Rod. J. Chromatogr. A, 2006, 1124 (1-2), 112-120. https://doi.org/10.1016/j.chroma.2006.05.062.

[344] Ahmadi, F.; Sparham, C.; Boyacl, E.; Pawliszyn, J. Time Weighted Average Concentration Monitoring Based on Thin Film Solid Phase Microextraction. Environ. Sci. Technol., 2017, 51 (7), 3929-3937. https://doi.org/10.1021/acs.est.6b06465.

[345] Santos, D. M.; Williams, M.; Kookana, R.; De Marchi, M. R. R. Solid Phase Microextraction (SPME) Fibers: In Situ Measurements of Endocrine Disrupting Chemicals in Seawater. J. Braz. Chem. Soc., 2018, 29 (4), 888-894. https://doi.org/10.21577/0103-5053.20170193.

[346] Cornelissen, G.; Arp, H. P. H.; Pettersen, A.; Hauge, A.; Breedveld, G. D. Assessing PAH and PCB Emissions from the Relocation of Harbour Sediments Using Equilibrium Passive Samplers. Chemosphere, 2008, 72 (10), 15811587. https://doi.org/10.1016/j.chemosphere.2008.04.041.

[347] Cornelissen, G.; Wiberg, K.; Broman, D. A. G.; Arp, H. P. H.; Persson, Y.; Sundqvist, K.; Jonsson, P. Freely Dissolved Concentrations and Sediment-Water Activity Ratios of PCDD/Fs and PCBs in the Open Baltic Sea. Environ. Sci. Technol., 2008, 42 (23), 8733-8739. https://doi.org/10.1021/es8018379.

[348] Carlsson, P.; Cornelissen, G.; Bøggild, C. E.; Rysgaard, S.; Mortensen, J.; Kallenborn, R. Hydrology-Linked Spatial Distribution of Pesticides in a Fjord System in Greenland. J. Environ. Monit., 2012, 14 (5), 1437-1443. https://doi.org/10.1039/c2em30068k.

[349] Josefsson, S.; Karlsson, O. M.; Malmaeus, J. M.; Cornelissen, G.; Wiberg, K. Structure-Related Distribution of PCDD/Fs, PCBs and HCB in a River-Sea System. Chemosphere, 2011, 83 (2), 85-94. https://doi.org/10.1016/j.chemosphere.2011.01.019.

[350] St. George, T.; Vlahos, P.; Harner, T.; Helm, P.; Wilford, B. A Rapidly Equilibrating, Thin Film, Passive Water Sampler for Organic Contaminants; Characterization and Field Testing. Environ. Pollut., 2011, 159 (2), 481-486. 
https://doi.org/10.1016/j.envpol.2010.10.030.

[351] Mijangos, L.; Ziarrusta, H.; Prieto, A.; Zugazua, O.; Zuloaga, O.; Olivares, M.; Usobiaga, A.; Paschke, A.; Etxebarria, N. Evaluation of Polar Organic Chemical Integrative and Hollow Fibre Samplers for the Determination of a Wide Variety of Organic Polar Compounds in Seawater. Talanta, 2018, 185, 469-476.

https://doi.org/10.1016/j.talanta.2018.03.103.

[352] Posada-Ureta, O.; Olivares, M.; Zatón, L.; Delgado, A.; Prieto, A.; Vallejo, A.; Paschke, A.; Etxebarria, N. Uptake Calibration of Polymer-Based Passive Samplers for Monitoring Priority and Emerging Organic Non-Polar Pollutants in WWTP Effluents. Anal. Bioanal. Chem., 2016, 408 (12), 3165-3175. https://doi.org/10.1007/s00216016-9381-7.

[353] Posada-Ureta, O.; Olivares, M.; Delgado, A.; Prieto, A.; Vallejo, A.; Irazola, M.; Paschke, A.; Etxebarria, N. Applicability of Polydimethylsiloxane (PDMS) and Polyethersulfone (PES) as Passive Samplers of More Hydrophobic Organic Compounds in Intertidal Estuarine Environments. Sci. Total Environ., 2017, 578, 392-398. https://doi.org/10.1016/j.scitotenv.2016.10.194.

[354] Narvaez, V. J. F.; Lopez, C. A.; Molina, P. F. J. Passive Sampling in the Study of Dynamic and Environmental Impact of Pesticides in Water. Rev. Fac. Ing., 2013, No. 68, 147-159.

[355] Esteve-Turrillas, F. A.; Pastor, A.; Yusà, V.; de la Guardia, M. Using Semi-Permeable Membrane Devices as Passive Samplers. TrAC - Trends Anal. Chem., 2007, 26 (7), 703-712. https://doi.org/10.1016/j.trac.2007.05.006.

[356] Muir, D.; Lohmann, R. Water as a New Matrix for Global Assessment of Hydrophilic POPs. TrAC - Trends Anal. Chem., 2013, 46, 162-172. https://doi.org/10.1016/j.trac.2012.12.019.

[357] Wong, C. S.; MacLeod, S. L. JEM Spotlight: Recent Advances in Analysis of Pharmaceuticals in the Aquatic Environment. J. Environ. Monit., 2009, 11 (5), 923-936. https://doi.org/10.1039/b819464e.

[358] Bayen, S.; Laak, T. L. T.; Buffle, J.; Hermens, J. L. M. Dynamic Exposure of Organisms and Passive Samplers to Hydrophobic Chemicals. Environ. Sci. Technol., 2009, 43 (7), 2206-2215. https://doi.org/10.1021/es8029895.

[359] Gourlay-Francé, C.; Gonzalez, J.-L. Use of passive samplers to evaluate water chemical contamination . Tech. - Sci. - Methodes, 2010, No. 3, 24-35.

[360] Lohmann, R.; Booij, K.; Smedes, F.; Vrana, B. Use of Passive Sampling Devices for Monitoring and Compliance Checking of POP Concentrations in Water. Environ. Sci. Pollut. Res., 2012, 19 (6), 1885-1895. https://doi.org/10.1007/s11356-012-0748-9.

[361] Jones, L.; Ronan, J.; McHugh, B.; McGovern, E.; Regan, F. Emerging Priority Substances in the Aquatic Environment: A Role for Passive Sampling in Supporting WFD Monitoring and Compliance. Analytical Methods. 2015. https://doi.org/10.1039/c5ay01059d.

[362] Prieto, A.; Basauri, O.; Rodil, R.; Usobiaga, A.; Fernández, L. A.; Etxebarria, N.; Zuloaga, O. Stir-Bar Sorptive Extraction: A View on Method Optimisation, Novel Applications, Limitations and Potential Solutions. $J$. Chromatogr. A, 2010, 1217 (16), 2642-2666. https://doi.org/10.1016/j.chroma.2009.12.051.

[363] Charriau, A.; Lissalde, S.; Poulier, G.; Mazzella, N.; Buzier, R.; Guibaud, G. Overview of the Chemcatcher ${ }^{\circledR}$ for the Passive Sampling of Various Pollutants in Aquatic Environments Part A: Principles, Calibration, Preparation and Analysis of the Sampler. Talanta, 2016, 148, 556-571. https://doi.org/10.1016/j.talanta.2015.06.064.

[364] Lissalde, S.; Charriau, A.; Poulier, G.; Mazzella, N.; Buzier, R.; Guibaud, G. Overview of the Chemcatcher ${ }^{\circledR}$ for the Passive Sampling of Various Pollutants in Aquatic Environments Part B: Field Handling and Environmental Applications for the Monitoring of Pollutants and Their Biological Effects. Talanta, 2016, 148, 572-582. https://doi.org/10.1016/j.talanta.2015.06.076.

[365] Ahkola, H.; Herve, S.; Knuutinen, J. Overview of Passive Chemcatcher Sampling with SPE Pretreatment Suitable for the Analysis of NPEOs and NPs. Environ. Sci. Pollut. Res., 2013, 20 (3), 1207-1218. https://doi.org/10.1007/s11356-012-1153-0.

[366] Mills, G. A.; Greenwood, R.; Vrana, B.; Allan, I. J.; Ocelka, T. Measurement of Environmental Pollutants Using Passive Sampling Devices - A Commentary on the Current State of the Art. J. Environ. Monit., 2011, 13 (11), 2979-2982. https://doi.org/10.1039/c1em10680e.

[367] Komarova, T.; Bartkow, M.; Müller, J.; Carter, S.; Vanderzalm, J. Field Evaluation of Passive Samplers: Monitoring Polycyclic Aromatic Hydrocarbons (PAHs) in Stormwater. Polycycl. Aromat. Compd., 2006, 26 (3), 221-236. https://doi.org/10.1080/10406630600760584.

[368] Page, D.; Miotliński, K.; Gonzalez, D.; Barry, K.; Dillon, P.; Gallen, C. Environmental Monitoring of Selected Pesticides and Organic Chemicals in Urban Stormwater Recycling Systems Using Passive Sampling Techniques. $J$. Contam. Hydrol., 2014, 158, 65-77. https://doi.org/10.1016/j.jconhyd.2014.01.004.

[369] Vrana, B.; Smedes, F.; Allan, I.; Rusina, T.; Okonski, K.; Hilscherová, K.; Novák, J.; Tarábek, P.; Slobodník, J. Mobile Dynamic Passive Sampling of Trace Organic Compounds: Evaluation of Sampler Performance in the Danube River. Sci. Total Environ., 2018, 636, 1597-1607. https://doi.org/10.1016/j.scitotenv.2018.03.242.

[370] Ahrens, L.; Daneshvar, A.; Lau, A. E.; Kreuger, J. Concentrations, Fluxes and Field Calibration of Passive Water Samplers for Pesticides and Hazard-Based Risk Assessment. Sci. Total Environ., 2018, 637-638, 835-843. https://doi.org/10.1016/j.scitotenv.2018.05.039.

[371] Liao, C.; Richards, J.; Taylor, A. R.; Gan, J. Development of Polyurethane-Based Passive Samplers for Ambient Monitoring of Urban-Use Insecticides in Water. Environ. Pollut., 2017, 231, 1412-1420. https://doi.org/10.1016/j.envpol.2017.09.002.

[372] Emelogu, E. S.; Pollard, P.; Robinson, C. D.; Webster, L.; McKenzie, C.; Napier, F.; Steven, L.; Moffat, C. F. Identification of Selected Organic Contaminants in Streams Associated with Agricultural Activities and Comparison between Autosampling and Silicone Rubber Passive Sampling. Sci. Total Environ., 2013, 445-446, 261-272. https://doi.org/10.1016/j.scitotenv.2012.12.053.

[373] Anderson, K. A.; Sethajintanin, D.; Sower, G.; Quarles, L. Field Trial and Modeling of Uptake Rates of in Situ 
Lipid-Free Polyethylene Membrane Passive Sampler. Environ. Sci. Technol., 2008, 42 (12), 4486-4493. https://doi.org/10.1021/es702657n.

[374] Ahrens, L.; Daneshvar, A.; Lau, A. E.; Kreuger, J. Characterization and Application of Passive Samplers for Monitoring of Pesticides in Water. J. Vis. Exp., 2016, 2016 (114). https://doi.org/10.3791/54053.

[375] Jacquet, R.; Miège, C.; Smedes, F.; Tixier, C.; Tronczynski, J.; Togola, A.; Berho, C.; Valor, I.; Llorca, J.; Barillon, B.; et al. Comparison of Five Integrative Samplers in Laboratory for the Monitoring of Indicator and Dioxin-like Polychlorinated Biphenyls in Water. Chemosphere, 2014, 98, 18-27.

https://doi.org/10.1016/j.chemosphere.2013.09.011.

[376] Perron, M. M.; Burgess, R. M.; Suuberg, E. M.; Cantwell, M. G.; Pennell, K. G. Performance of Passive Samplers for Monitoring Estuarine Water Column Concentrations: 2. Emerging Contaminants. Environ. Toxicol. Chem., 2013, 32 (10), 2190-2196. https://doi.org/10.1002/etc.2248.

[377] Ahrens, L.; Daneshvar, A.; Lau, A. E.; Kreuger, J. Characterization of Five Passive Sampling Devices for Monitoring of Pesticides in Water. J. Chromatogr. A, 2015, 1405, 1-11. https://doi.org/10.1016/j.chroma.2015.05.044.

[378] Miège, C.; Schiavone, S.; Dabrin, A.; Coquery, M.; Mazzella, N.; Berho, C.; Ghestem, J.-P.; Togola, A.; Gonzalez, C.; Gonzalez, J.-L.; et al. An in Situ Intercomparison Exercise on Passive Samplers for Monitoring Metals, Polycyclic Aromatic Hydrocarbons and Pesticides in Surface Waters. TrAC - Trends Anal. Chem., 2012, 36, 128143. https://doi.org/10.1016/j.trac.2012.01.009.

[379] Qian, J.; Jennings, B.; Cwiertny, D. M.; Martinez, A. Emerging Investigator Series: Development and Application of Polymeric Electrospun Nanofiber Mats as Equilibrium-Passive Sampler Media for Organic Compounds. Environ. Sci. Process. Impacts, 2017, 19 (11), 1445-1456. https://doi.org/10.1039/c7em00289k.

[380] ISO (International Organization for Standardization). ISO 5667-23:2011. Water Quality -- Sampling -- Part 23: Guidance on Passive Sampling in Surface Waters; Switzerland, 2011. 
Figures and Tables

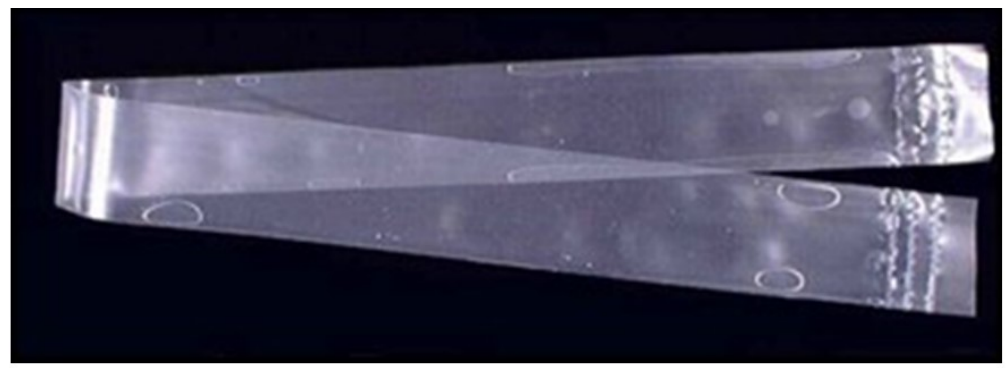

a

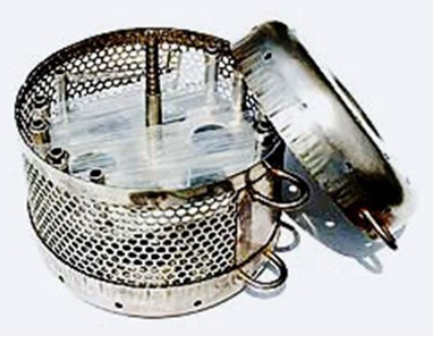

b

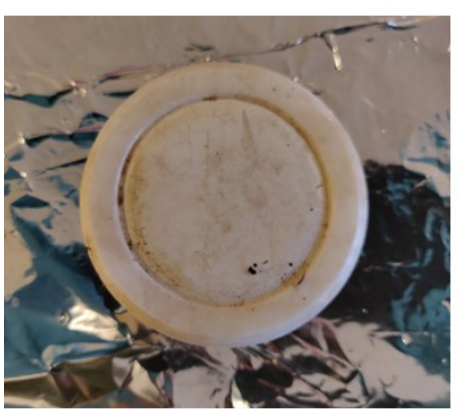

C

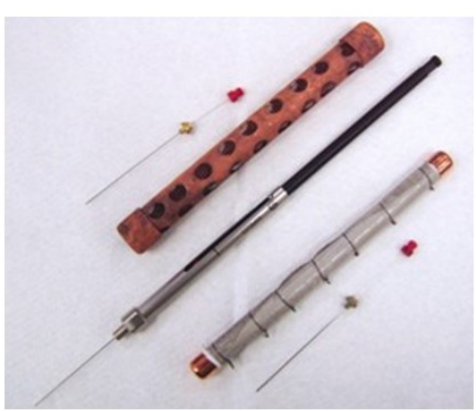

d

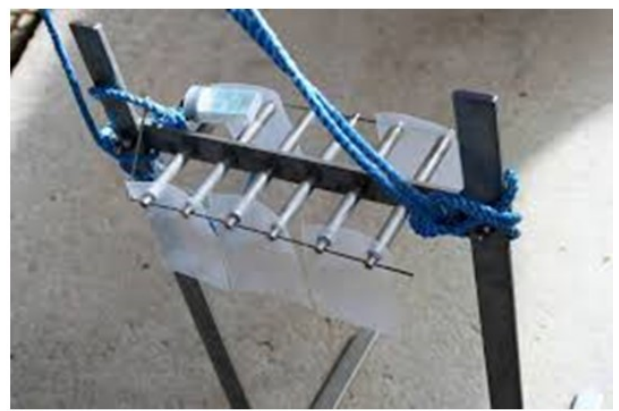

$\mathrm{e}$

Figure 1. Passive sampling devices together with deployment apparatus used for monitoring hydrophobic organic compounds in water (a) semi-permeable membrane device, (b) semipermeable membrane device mounted in deployment canister, (c) Chemcatcher $^{\circledR}$, (d) a selection of solid-phase microextraction devices, (e) silicone rubber membranes mounted in a deployment rig. 
SPMD

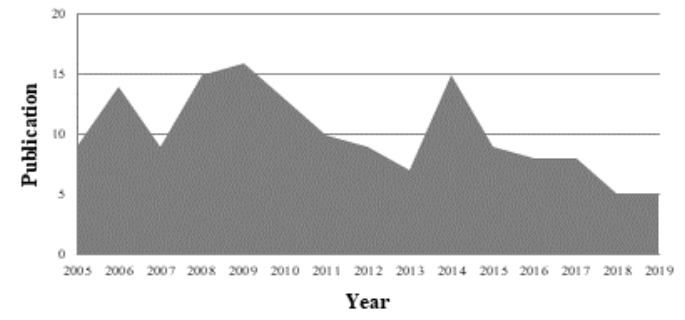

LDPE

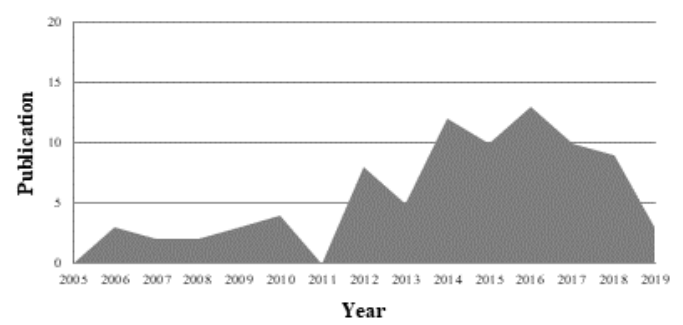

SPME

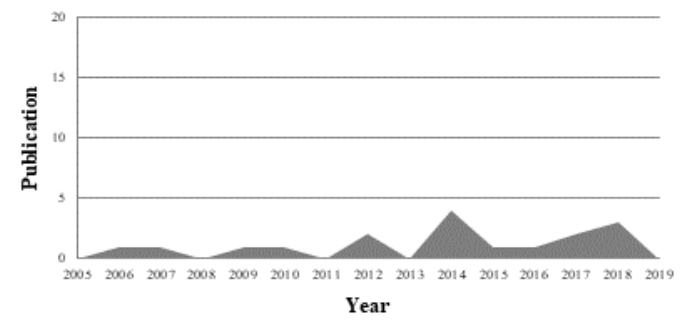

Silicone

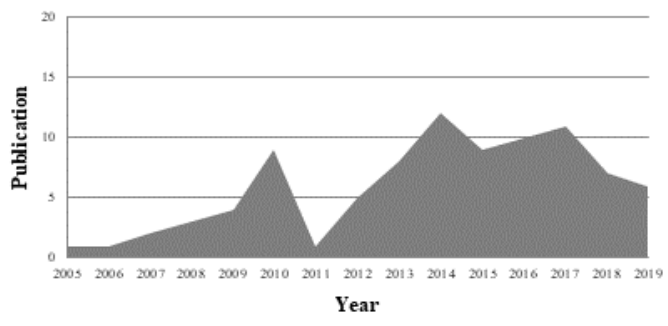

Chemcatcher $\mathbb{B}$

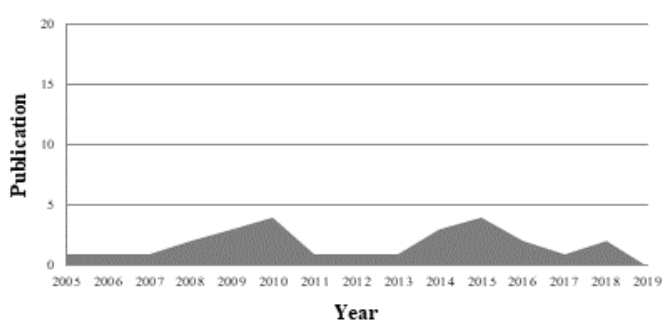

Other polymers

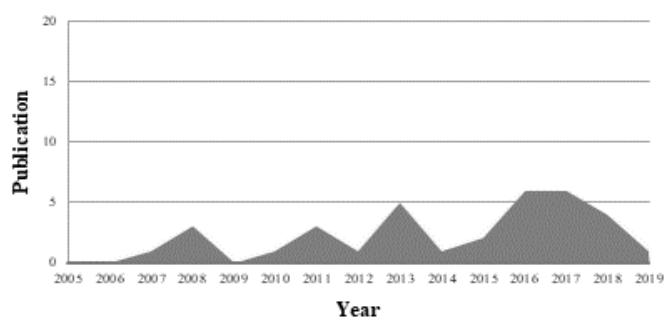

Figure 2. Number of publications per year (2005-2019 in part) that described the use of passive sampling for measuring HOCs in water. 
Table 1

Comparison of design, performance and availability of PSDs used for monitoring HOCs

*typical range over which device is used.

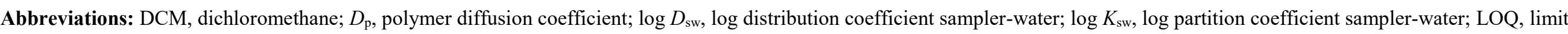

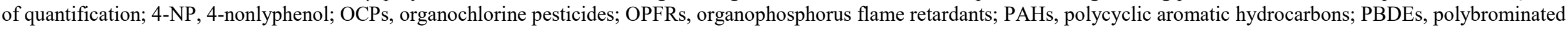
diphenyl ethers; PCBs, polychlorinated biphenyls; PDMS, polydimethylsiloxane; PSD, passive sampling device; $t_{\mathrm{eq}}$, time to equilibration; WBL, water boundary layer.

\begin{tabular}{|c|c|c|c|c|c|c|c|c|c|c|c|c|}
\hline \multirow[b]{2}{*}{$\begin{array}{c}\text { Passive } \\
\text { sampling } \\
\text { device }\end{array}$} & \multicolumn{3}{|c|}{ Practical aspects } & \multicolumn{6}{|c|}{ Performance } & \multicolumn{2}{|c|}{ Availability } & \multirow[b]{2}{*}{$R$ e $f$} \\
\hline & Specification & Versatility & $\begin{array}{l}\text { Preparation and } \\
\text { extraction }\end{array}$ & $\begin{array}{l}\text { Uptake and } \\
\text { selectivity* } \\
(\log \text { Kow })\end{array}$ & Analyte & $\begin{array}{c}R_{\mathrm{S}} \\
\left(\mathbf{L ~ d ~ d ~}^{-1}\right. \\
\left.\mathbf{c m}^{-2}\right)\end{array}$ & $\log K_{\mathrm{SW}}$ & $\begin{array}{c}t_{\mathrm{eq}} \\
\text { (days) }\end{array}$ & $\begin{array}{c}\text { LOQ } \\
\left(n g L^{-1}\right)\end{array}$ & $\begin{array}{l}\text { Commercial } \\
\text { ly available }\end{array}$ & Cost & \\
\hline \multirow{4}{*}{ SPMD } & \multirow{4}{*}{$\begin{array}{c}\text { Standard - } 106 \times 2.54 \\
\text { cm LDPE lay flat } \\
\text { tube (thickness } 70-95 \\
\mu \mathrm{m}) \text { containing } 1 \mathrm{~mL} \\
\text { triolein (sampling } \\
\text { area/triolein ratio }= \\
460 \mathrm{~cm}^{2} \mathrm{~mL}^{-1} \text { ). } \\
\text { Miniaturized devices } \\
\text { or devices with } \\
\text { alternate membrane } \\
\text { and/or internal } \\
\text { receiving phases are } \\
\text { sometimes used. }\end{array}$} & \multirow{4}{*}{$\begin{array}{l}\text { Not reusable. } \\
\text { Deployment in } \\
\text { protective } \\
\text { cage to avoid } \\
\text { damage during } \\
\text { deployment. } \\
\text { Degradation of } \\
\text { sequestered } \\
\text { analytes may } \\
\text { occur if PSD } \\
\text { is exposed to } \\
\text { sunlight. }\end{array}$} & \multirow{4}{*}{$\begin{array}{l}\text { Complicated sample } \\
\text { clean-up; dialysis, } \\
\text { accelerated solvent } \\
\text { extraction, microwave } \\
\text { assisted extraction } \\
\text { ultrasonic extraction. } \\
\text { (solvents: } n \text {-hexane, } \\
n \text {-hexane-DCM, } n \text { - } \\
\text { hexane-acetone, } \\
\text { toluene, cyclohexane } \\
\text { or cyclopentane). }\end{array}$} & \multirow{4}{*}{$\begin{array}{l}\text { WBL } \\
\text { controlled } \\
(3-10)\end{array}$} & PAHs & $\begin{array}{l}\sim 0.04- \\
0.40\end{array}$ & $2.28-5.70$ & \multirow{4}{*}{$7-<28$} & 0.03 & \multirow{4}{*}{$\begin{array}{l}\text { Yes - } \\
\text { constructed } \\
\text { devices and } \\
\text { component } \\
\text { parts can be } \\
\text { purchased } \\
\text { from several } \\
\text { suppliers. }\end{array}$} & \multirow{4}{*}{$\$ \$ \$$} & \multirow{4}{*}{$\begin{array}{l}{[11,37,} \\
67-70]\end{array}$} \\
\hline & & & & & PCBs & $\begin{array}{c}\sim 0.09- \\
0.40\end{array}$ & $3.89-7.85$ & & 0.01 & & & \\
\hline & & & & & OCPs & $\begin{array}{l}\sim 0.17- \\
0.30\end{array}$ & $2.94-5.70$ & & 0.02 & & & \\
\hline & & & & & PBDEs & - & $4.48-5.69$ & & 0.001 & & & \\
\hline \multirow{7}{*}{ Silicone rubber } & \multirow{7}{*}{$\begin{array}{l}\text { Single phase PSD } \\
\text { comprised of multiple } \\
\text { sheets (approx. } 0.5 \\
\text { mm thick) with a } \\
\text { combined sampling } \\
\text { area of } 300-600 \mathrm{~cm}^{2} .\end{array}$} & \multirow{7}{*}{$\begin{array}{l}\text { Can be reused } \\
\text { if cleaned. } \\
\text { Multiple } \\
\text { sheets can be } \\
\text { combined to } \\
\text { form one } \\
\text { device. }\end{array}$} & \multirow{7}{*}{$\begin{array}{l}\text { Oligomers must be } \\
\text { removed before use } \\
\text { this takes time and } \\
\text { solvent. Soxhlet } \\
\text { extraction (solvents: } \\
\text { methanol-acetonitrile, } \\
1: 2 \mathrm{v} / \mathrm{v} \text { or methanol). }\end{array}$} & \multirow{7}{*}{$\begin{array}{c}\text { WBL } \\
\text { controlled } \\
(3-7)\end{array}$} & PAHs & $\begin{array}{l}0.007- \\
0.032 \\
\end{array}$ & $3.03-6.24$ & \multirow{7}{*}{$\begin{array}{l}\text { Weeks- } \\
\text { months }\end{array}$} & 0.001 & \multirow{7}{*}{$\begin{array}{l}\text { No - } \\
\text { Polymer } \\
\text { formulation } \\
\text { may differ } \\
\text { between } \\
\text { suppliers. }\end{array}$} & \multirow{7}{*}{$\$ \$$} & \multirow{7}{*}{$\begin{array}{l}{[12,14,} \\
19,26, \\
71-74]\end{array}$} \\
\hline & & & & & PCBs & $\begin{array}{l}0.006- \\
0.015 \\
\end{array}$ & $3.63-7.12$ & & 0.002 & & & \\
\hline & & & & & OCPs & 0.150 & $2.28-6.27$ & & - & & & \\
\hline & & & & & PBDEs & - & 4.29-5.29 & & - & & & \\
\hline & & & & & $\begin{array}{l}\text { Musks } \\
\text { 4-NP }\end{array}$ & $\begin{array}{l}- \\
-\end{array}$ & $\begin{array}{c}4.29-5.37 \\
4.62\end{array}$ & & $\begin{array}{c}40-1500 \\
570\end{array}$ & & & \\
\hline & & & & & $\frac{\text { 4-Nir }}{\text { Triclosan }}$ & - & $\begin{array}{l}4.02 \\
3.89 \\
\end{array}$ & & 4 & & & \\
\hline & & & & & OPFRs & - & $3.05-6.36$ & & 10 & & & \\
\hline \multirow{4}{*}{ LDPE } & \multirow{4}{*}{$\begin{array}{l}\text { Single phase PSD } \\
\text { comprised of multiple } \\
\text { sheets (approx. } 0.1 \\
\text { mm thick) with a } \\
\text { combined sampling } \\
\text { area of } 324 \mathrm{~cm}^{2} \text {. }\end{array}$} & \multirow{4}{*}{$\begin{array}{c}\text { Non-reusable } \\
\text { sheets can be } \\
\text { damaged, use } \\
\text { in aquatic, } \\
\text { sediment and } \\
\text { atmospheric } \\
\text { phases well } \\
\text { described. }\end{array}$} & \multirow{4}{*}{$\begin{array}{l}\text { Preparation and } \\
\text { extraction easier than } \\
\text { SPMD with similar } \\
\text { sensitivity and } \\
\text { selectivity. }\end{array}$} & \multirow{4}{*}{$\begin{array}{c}\text { WBL } \\
\text { controlled } \\
(3-7)\end{array}$} & PAHs & $0.17-10$ & $2.74-7.84$ & \multirow{4}{*}{$7-<56$} & 0.2 & \multirow{4}{*}{$\begin{array}{l}\text { No - } \\
\text { Polymer } \\
\text { formulation } \\
\text { may differ } \\
\text { between } \\
\text { suppliers. }\end{array}$} & \multirow{4}{*}{$\$$} & \multirow{4}{*}{$\begin{array}{c}{[37,69,} \\
72,75- \\
79]\end{array}$} \\
\hline & & & & & PCBs & $\sim 0.1-0.4$ & $4.19-7.77$ & & 3 & & & \\
\hline & & & & & OCPs & $\begin{array}{c}0.15- \\
0.22 \\
\end{array}$ & $2.8-5.59$ & & - & & & \\
\hline & & & & & PBDEs & - & $4.2-7.6$ & & - & & & \\
\hline Chemcatcher $^{(B)}$ & $\begin{array}{l}\text { PTFE housing } 47 \mathrm{~mm} \\
\mathrm{C}_{18} \text { receiving disk }\end{array}$ & $\begin{array}{l}\text { Reusable } \\
\text { (housing }\end{array}$ & $\begin{array}{l}\text { Ultrasonic bath (5 } \\
\text { min) using acetone (5 }\end{array}$ & $\begin{array}{c}\text { WBL } \\
\text { controlled, }\end{array}$ & PAHs & $\begin{array}{c}0.009- \\
0.325 \\
\end{array}$ & $\begin{array}{c}3.66-5.4 \\
\left(\log D_{\mathrm{sw}}\right)\end{array}$ & $\begin{array}{c}<28- \\
(14 \\
\end{array}$ & $0.1-83$ & $\begin{array}{c}\text { Yes - } \\
\text { Housing, }\end{array}$ & $\$ \$$ & $\begin{array}{l}36,69, \\
80-83] \\
\end{array}$ \\
\hline
\end{tabular}




\begin{tabular}{|c|c|c|c|c|c|c|c|c|c|c|c|c|}
\hline \multirow[b]{2}{*}{$\begin{array}{c}\text { Passive } \\
\text { sampling } \\
\text { device }\end{array}$} & \multicolumn{3}{|c|}{ Practical aspects } & \multicolumn{6}{|c|}{ Performance } & \multicolumn{2}{|c|}{ Availability } & \multirow[b]{2}{*}{$R$ e $f$} \\
\hline & Specification & Versatility & $\begin{array}{l}\text { Preparation and } \\
\text { extraction }\end{array}$ & $\begin{array}{c}\text { Uptake and } \\
\text { selectivity* } \\
\text { (log Kow) }\end{array}$ & Analyte & $\begin{array}{c}R \mathrm{~s} \\
\left(\mathbf{L ~ d}^{-1}\right. \\
\left.\mathbf{c m}^{-2}\right)\end{array}$ & $\log K$ sw & $\begin{array}{c}t_{\mathrm{eq}} \\
\text { (days) }\end{array}$ & $\begin{array}{c}\text { LOQ } \\
\left(n g L^{-1}\right)\end{array}$ & $\begin{array}{l}\text { Commercial } \\
\text { ly available }\end{array}$ & Cost & \\
\hline & \multirow{3}{*}{$\begin{array}{c}(600 \mu \mathrm{L}) \text { and } 450 \mu \mathrm{L} \\
n \text {-octanol, overlain } \\
\text { with LDPE DM, } \\
\text { sampling area }=17 \\
\mathrm{~cm}^{2} .\end{array}$} & \multirow{3}{*}{$\begin{array}{c}\text { only). } \\
\text { Multiple } \\
\text { devices may } \\
\text { be needed to } \\
\text { achieve low } \\
\text { LOQ. }\end{array}$} & \multirow{3}{*}{$\begin{array}{l}\mathrm{mL}) \text { followed by } 5 \\
\mathrm{~min} \text { in } 50: 50(\mathrm{v} / \mathrm{v}) \\
\text { ethyl acetate: } 2,2,4- \\
\text { trimethylpentane ( } 5 \\
\mathrm{~mL})\end{array}$} & \multirow{3}{*}{$\begin{array}{l}n \text {-octanol } \\
\text { added to } \\
\text { increase } \\
\text { internal } \\
\text { diffusion } \\
(3.5-7) \\
\end{array}$} & PCBs & $\begin{array}{l}0.19- \\
0.89 \\
\end{array}$ & - & \multirow{3}{*}{$\begin{array}{l}\text { days } \\
\text { linear } \\
\text { for } \\
\text { most } \\
\text { compou } \\
\text { nds) }\end{array}$} & - & \multirow{3}{*}{$\begin{array}{l}\mathrm{DM} \text { and } \\
\text { receiving } \\
\text { phases can } \\
\text { be } \\
\text { purchased. }\end{array}$} & & \\
\hline & & & & & PBDEs & $\begin{array}{c}0.15- \\
0.58\end{array}$ & - & & $0.04-1$ & & & \\
\hline & & & & & OCPs & $\begin{array}{c}0.44- \\
0.81\end{array}$ & - & & $0.2-40$ & & & \\
\hline \multirow{2}{*}{ SPME } & \multirow{2}{*}{$\begin{array}{l}1 \mathrm{~cm} \text { long, } 7,30 \text { or } \\
100 \mu \mathrm{m} \text { thick sorbent } \\
\text { coated fibre (typically } \\
\text { PDMS) which may } \\
\text { be recessed in a } \\
\text { sheath. Other SPME } \\
\text { may be rods of larger } \\
\text { dimension. }\end{array}$} & \multirow{2}{*}{$\begin{array}{l}\text { Reusable } \\
\text { (damage may } \\
\text { occur over } \\
\text { time, due to } \\
\text { thermal } \\
\text { desorption). }\end{array}$} & \multirow{2}{*}{$\begin{array}{l}\text { Thermal desorption } \\
\text { (head space), this can } \\
\text { be automated and } \\
\text { requires no solvent. } \\
\text { Matrix effects } \\
\text { common and LOQ is } \\
\text { higher than other } \\
\text { PSDs. No extract } \\
\text { retained so reanalysis } \\
\text { not possible. }\end{array}$} & \multirow{2}{*}{$\begin{array}{c}\text { SPME } \\
\text { sheath can } \\
\text { be altered to } \\
\text { control } \\
\text { uptake } \\
\text { (2-7, } \\
\text { PDMS) }\end{array}$} & PAHs & $\begin{array}{c}0.005- \\
6.6(\mathrm{~mL} \\
\left.\mathrm{d}^{-1}\right)\end{array}$ & $3.32-5.13$ & \multirow{2}{*}{$>1-63$} & - & \multirow{2}{*}{$\begin{array}{l}\text { Yes - Can } \\
\text { be } \\
\text { purchased, } \\
\text { used widely } \\
\text { in sample } \\
\text { separation. }\end{array}$} & \multirow{2}{*}{$\$ \$$} & \multirow{2}{*}{$\begin{array}{c}{[22,23,} \\
79,84, \\
85]\end{array}$} \\
\hline & & & & & PCBs & $\begin{array}{c}5.68- \\
6.48 \\
\left(\mathrm{~mL} \mathrm{~d}^{-1}\right)\end{array}$ & $4.09-7.05$ & & $\begin{array}{l}300- \\
8000\end{array}$ & & & \\
\hline \multirow{3}{*}{ POM } & \multirow{3}{*}{$\begin{array}{l}\text { Long strips (approx. } \\
0.055-0.5 \mathrm{~mm} \text { thick), } \\
\text { length tailored to } \\
\text { deployment needs. }\end{array}$} & \multirow{3}{*}{$\begin{array}{l}\text { Deployed } \\
\text { directly in the } \\
\text { water column, } \\
\text { no cages or } \\
\text { housing } \\
\text { needed. }\end{array}$} & \multirow{3}{*}{$\begin{array}{l}\text { Cleaned by sequential } \\
\text { extraction in } n \text {-hexane } \\
\text { followed by methanol } \\
\text { for } 2 \mathrm{~h} \text { with extraction } \\
\text { in } 1: 1 \text { acetone: } n \text { - } \\
\text { hexane, or other } \\
\text { solvent such as DCM. } \\
\text { Extraction can be } \\
\text { aided by sonication } \\
\text { and may need to be } \\
\text { repeated to enhance } \\
\text { recovery. Analyte } \\
\text { migration in stored } \\
\text { PSDs can bias results. } \\
\text { Very clean extracts } \\
\text { due to low } D_{\mathrm{p}} \text {. }\end{array}$} & \multirow{3}{*}{$\begin{array}{l}\text { Diffusion } \\
\text { (polymer) } \\
\text { controlled } \\
\quad(3-7)\end{array}$} & PAHs & - & $3.23-5.15$ & \multirow{3}{*}{$\begin{array}{l}>1-119 \\
(>1 \\
\text { month } \\
\text { for } \\
\text { many } \\
\text { compou } \\
\text { nds) }\end{array}$} & $>0.01-1$ & \multirow{3}{*}{$\begin{array}{l}\text { Yes - } \\
\text { Conditioned } \\
\text { polymer } \\
\text { strips can be } \\
\text { purchased. }\end{array}$} & \multirow{3}{*}{$\begin{array}{l}\$ \$- \\
\$ \$ \$\end{array}$} & \multirow{3}{*}{$\begin{array}{c}{[23,72,} \\
79,86- \\
89]\end{array}$} \\
\hline & & & & & PCBs & - & $4.44-6.2$ & & $\begin{array}{c}>0.001- \\
0.08\end{array}$ & & & \\
\hline & & & & & OCPs & - & $3.67-5.66$ & & - & & & \\
\hline
\end{tabular}

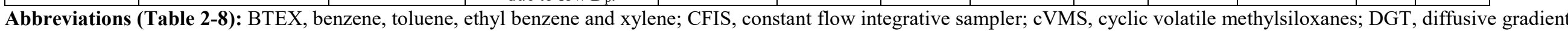

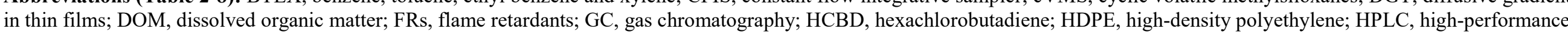

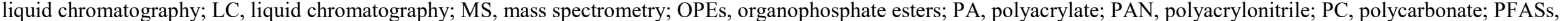

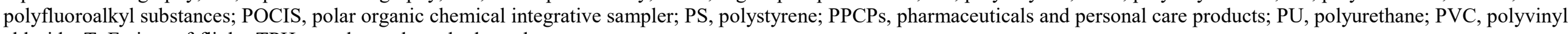
chloride; ToF, time-of-flight; TPHs, total petroleum hydrocarbons. 
Table 2

Applications of the semipermeable membrane device

\begin{tabular}{|c|c|c|c|}
\hline Environment & Analytes & Description & Ref \\
\hline \multicolumn{4}{|c|}{ Monitoring of process efficacy } \\
\hline $\begin{array}{l}\text { Drinking water } \\
\text { treatment }\end{array}$ & PAHs & $\begin{array}{l}\text { Long- and short-term monitoring at various stages of drinking water treatment through a range of chemical } \\
\text { analysis and bioassays. }\end{array}$ & {$[122-124]$} \\
\hline $\begin{array}{l}\text { Wastewater } \\
\text { treatment }\end{array}$ & $\begin{array}{l}\text { EDCs; PAHs; } \\
\text { PBDEs; PCBs; } \\
\text { pesticides; synthetic } \\
\text { musk's }\end{array}$ & $\begin{array}{l}\text { SPMDs deployed alongside biota and PSDs (artificial mussels, active sampling, numerical simulations, fish, } \\
\text { DGTs and POCIS,) at various stages in primary, secondary and advanced wastewater treatment processes to } \\
\text { measure process efficacy through the concentration (freely dissolved and particulate phase) of a range of HOCs } \\
\text { including the effects of factors such as of temporal fluctuation in influent quality and climatic conditions. }\end{array}$ & {$[127-133]$} \\
\hline $\begin{array}{l}\text { Petroleum } \\
\text { wastewater } \\
\text { treatment }\end{array}$ & PAHs; TPHs & $\begin{array}{l}\text { SPMDs used to monitor the efficacy of a range of processes (activated carbon, activated sludge, anthracite and } \\
\text { zeolite) in petroleum wastewaters through chemical analysis and ecotoxicological assessment. }\end{array}$ & {$[125,126]$} \\
\hline \multicolumn{4}{|c|}{ Monitoring of discharges and dispersal of pollutants } \\
\hline $\begin{array}{l}\text { Wastewater } \\
\text { treatment }\end{array}$ & $\begin{array}{l}\text { PCBs; pesticides; } \\
\text { synthetic musk's; } \\
\text { triclocarban }\end{array}$ & $\begin{array}{l}\text { SPMDs deployed, including alongside POCIS, at various locations in raw and receiving waters to identify } \\
\text { sources, characterize concentrations and profiles and to describe the fate of wastewater associated HOCs at } \\
\text { downstream locations. }\end{array}$ & {$[149-152]$} \\
\hline Wetlands & PAHs & $\begin{array}{l}\text { SPMDs deployed alongside resident wood frog tadpoles in boreal wetlands near Alberta's oil sands. Sampler } \\
\text { extracts and collected tadpoles were analyzed to monitor the atmospheric deposition of PAHs in water bodies at } \\
\text { varying distances from oil sand mining operations. }\end{array}$ & {$[160]$} \\
\hline $\begin{array}{l}\text { Oil and gas } \\
\text { produced water }\end{array}$ & PAHs & $\begin{array}{l}\text { Deployments of SPMDs in impacted marine waters, including alongside POCIS and biota (fish, oysters, } \\
\text { scallops and mussels) to monitor the freely dissolved concentration, dispersal and bioaccumulation of HOCs } \\
\text { associated with produced water and research and methodological gaps for passive sampling within Norwegian } \\
\text { produced water monitoring guidance. }\end{array}$ & {$[137-142]$} \\
\hline $\begin{array}{l}\text { Paper mill } \\
\text { wastewater }\end{array}$ & Dioxins; EDCs & $\begin{array}{l}\text { SPMDs deployed at sites upstream and downstream of the effluent outfalls of paper mills on the Androscoggin } \\
\text { River (USA) and the Biobio River (Chile), to monitor HOCs produced during the bleaching of paper and pulp, } \\
\text { through chemical analysis and bioassays of SPMD extracts respectively. }\end{array}$ & {$[144,145]$} \\
\hline $\begin{array}{l}\text { Oil spill (marine } \\
\text { waters) }\end{array}$ & PAHs & $\begin{array}{l}\text { SPMDs deployed at three locations underneath ice flows over a six-day period following a } 7000 \mathrm{~L} \text { oil slick } \\
\text { (fresh crude oil) in the Barents Sea, to study oil transport and oil, water, ice interactions. }\end{array}$ & {$[157]$} \\
\hline $\begin{array}{l}\text { Coastal waters } \\
\text { (salvage) }\end{array}$ & PAHs & $\begin{array}{l}\text { SPMDs and DGTs deployed at sites in near the Costa Concordia shipwreck (Italy) to monitor the release and } \\
\text { dispersal of PAHs and trace metals over each stage of the } 2.5 \text {-year salvage operation. }\end{array}$ & {$[156]$} \\
\hline Pisciculture & PCBs; pesticides & $\begin{array}{l}\text { SPMD were deployed at sites upstream and downstream of a salmon spawning site on the Credit River } \\
\text { (Canada) to determine whether the death and decay of salmon after spawning causes the release to the aqueous } \\
\text { phase of bioaccumulated non-polar compounds at detectable concentrations. }\end{array}$ & {$[158]$} \\
\hline \multicolumn{4}{|c|}{ Chemical speciation, distribution and degradation } \\
\hline River waters & PAHs; PBDEs; PCBs & $\begin{array}{l}\text { SMPDs used alongside methods including grab sampling and statistical analysis of land use to attribute phase } \\
\text { specific (freely dissolved, apparently dissolved and particulate phase) sources, occurrence, concentrations and } \\
\text { fate of HOCs within river catchments. }\end{array}$ & {$[161,162]$} \\
\hline $\begin{array}{l}\text { River, lake, } \\
\text { coastal and } \\
\text { marine waters }\end{array}$ & $\begin{array}{l}\text { EDCs; PAHs; } \\
\text { PBDEs; PCBs; } \\
\text { pesticides; synthetic } \\
\text { musk's }\end{array}$ & $\begin{array}{l}\text { SPMDs, including alongside other PSDs such as POCIS and XAD-2 resin were deployed at depth intervals in } \\
\text { the water column at various sites to establish the vertical distribution in the bioavailability, concentration and } \\
\text { photo-degradation (within SPMDs) of a range of HOCs. }\end{array}$ & {$[163-166]$} \\
\hline
\end{tabular}




\begin{tabular}{|c|c|c|c|}
\hline Environment & Analytes & Description & Ref \\
\hline Coastal waters & Dioxins; PAHs; PCBs & $\begin{array}{l}\text { SPMDs deployed near activities causing disturbance of sediments (trawling and sediment relocation) to } \\
\text { determine whether said activities facilitate transfer of HOCs from the sediment to aqueous phase. }\end{array}$ & {$[171,172]$} \\
\hline Calibration tank & PAHs & $\begin{array}{l}\text { The bioavailability of HOCs was tested in a closed system by deploying SPMDs and Daphnia magna at a range } \\
\text { of different organic matter concentrations. }\end{array}$ & {$[174]$} \\
\hline Calibration tank & PAHs & $\begin{array}{l}\text { The effect of Nereis diversicolor bioturbation on the remobilization of PAHs from the sediment to aqueous } \\
\text { phase was determined through measuring release fluxes and mass transfer coefficients with SPMDs in } \\
\text { laboratory exposures. }\end{array}$ & {$[173]$} \\
\hline \multicolumn{4}{|c|}{ Monitoring spatial and temporal trends } \\
\hline River waters & $\begin{array}{l}\text { Dioxins; PAHs; } \\
\text { PBDEs; PCBs; } \\
\text { pesticides; synthetic } \\
\text { musk's }\end{array}$ & $\begin{array}{l}\text { SPMDs deployed, including alongside other methods and PSDs (grab sampling, POCIS and DGT), at various } \\
\text { locations on a number of rivers to measure the spatial and temporal variation in occurrence and concentration of } \\
\text { a range of HOCs through chemical analysis and bioassays. }\end{array}$ & $\begin{array}{l}{[70,190,} \\
200-206]\end{array}$ \\
\hline Coastal waters & $\begin{array}{l}\text { Dioxins; halogenated } \\
\text { organic chemicals; } \\
\text { PAHs; PCBs; } \\
\text { pesticides }\end{array}$ & $\begin{array}{l}\text { SPMDs deployed, including alongside other PSDs (Chemcatcher }{ }^{\mathbb{B}}, \text { POCIS and SR) and grab sampling, in } \\
\text { coastal waters to measure the spatial and temporal variation in occurrence and concentration of various HOCs. }\end{array}$ & {$[234-240]$} \\
\hline $\begin{array}{l}\text { Impounded } \\
\text { reservoir }\end{array}$ & $\begin{array}{l}\text { PAHs; PCBs; } \\
\text { pesticides }\end{array}$ & $\begin{array}{l}\text { PRC spiked SPMDs deployed, in the Three Gorges Dam (China) over the impoundment of the reservoir and } \\
\text { after impoundment to measure the spatial and temporal variation in HOC concentration. }\end{array}$ & {$[187-189]$} \\
\hline Marine waters & $\begin{array}{l}\text { PAHs; PBDEs; PCBs; } \\
\text { pesticides }\end{array}$ & $\begin{array}{l}\text { SPMDs, grab samples and fish bile collection used to monitor a range of HOCs during the Norwegian Tangaroa } \\
\text { balsa raft expedition in the Pacific in } 2006 \text {. }\end{array}$ & {$[208]$} \\
\hline Lake waters & $\begin{array}{l}\text { PCBs; synthetic } \\
\text { musk's; triclosan }\end{array}$ & $\begin{array}{l}\text { SPMDs alone and alongside POCIS were deployed at lake sites to monitor the bioavailable concentration of a } \\
\text { range of HOCs, this was compared to results obtained from grab samples or assessed in relation to limnology } \\
\text { and pollution sources of sampled waters. }\end{array}$ & {$[241,242]$} \\
\hline $\begin{array}{l}\text { Ground and } \\
\text { surface waters }\end{array}$ & $\begin{array}{l}\text { Dioxins; PAHs; } \\
\text { PCBs; pesticides }\end{array}$ & $\begin{array}{l}\text { Monitoring of temporal and spatial variation in HOC concentration with SPMDs, alone and alongside POCIS, } \\
\text { in karstic systems. }\end{array}$ & {$[243,244]$} \\
\hline \multicolumn{4}{|c|}{ Toxicity and toxicological monitoring } \\
\hline $\begin{array}{l}\text { Drinking water } \\
\text { treatment }\end{array}$ & $\begin{array}{l}\text { Dioxins; PAHs; } \\
\text { PCBs; pesticides }\end{array}$ & $\begin{array}{l}\text { Toxicity assessment of water with extracts from SPMDs deployed at different stages of drinking water } \\
\text { treatment using microtox, AhR agonist, cytotoxic and genotoxic bioassays. }\end{array}$ & $\begin{array}{l}{[59,245,} \\
246]\end{array}$ \\
\hline River waters & $\begin{array}{l}\text { Dioxins; PAHs; } \\
\text { PCBs; pesticides; } \\
\text { PPCPs }\end{array}$ & $\begin{array}{l}\text { Ecotoxicological risk assessment using a variety of methods such as active sampling, passive sampling (SPMD } \\
\text { and POCIS), Vtox, biota monitoring (mussel and fish tissue), to monitor for a variety of HOCs and biomarkers } \\
\text { of exposure in various rivers. }\end{array}$ & {$[247-251]$} \\
\hline River Waters & $\begin{array}{l}\text { Dioxins; EDCs; } \\
\text { PAHs; PCBs; } \\
\text { pesticides; triclosan }\end{array}$ & $\begin{array}{l}\text { Toxicological assessment of various rivers through chemical analysis (quantitative and screening) and various } \\
\text { bioassays of/with PSD extracts (SPMD and POCIS), biota and composite sampling, including bioassay driven } \\
\text { chemical analysis and observation of mortality and fertility. }\end{array}$ & $\begin{array}{l}{[55,57,58,} \\
60,252- \\
254]\end{array}$ \\
\hline Lake water & $\begin{array}{l}\text { Dioxins; EDCs; } \\
\text { PAHs; pesticides }\end{array}$ & $\begin{array}{l}\text { SPMDs including alongside biota (caged carp, resident fish and Common toad larvae), deployed in several } \\
\text { natural and impounded lakes to evaluate concentrations and toxicity potential of HOCs through combination of } \\
\text { chemical analysis, bioassays, and observation of mortality and fertility. }\end{array}$ & {$[255-257]$} \\
\hline Groundwater & $\begin{array}{l}\text { PAHs; PCBs; } \\
\text { pesticides }\end{array}$ & $\begin{array}{l}\text { SPMDs used to monitor HOCs in groundwater to determine natural background concentrations and any } \\
\text { secondary contamination and the associated toxicity of each. }\end{array}$ & {$[258]$} \\
\hline Coastal waters & PAHs & $\begin{array}{l}\text { SPMDs deployed alone and alongside mussels and analyzed chemically and with several bioassays to monitor } \\
\text { the concentrations of a range of environmental toxicants }\end{array}$ & {$[259,260]$} \\
\hline
\end{tabular}




\begin{tabular}{|c|c|c|c|}
\hline Environment & Analytes & Description & Ref \\
\hline $\begin{array}{l}\text { Calibration tank, } \\
\text { river and lake } \\
\text { waters }\end{array}$ & PAHs; pesticides & Investigations of the performance of variations of the SPMD with altered membranes and/or receiving phase. & {$[270-272]$} \\
\hline River waters & $\begin{array}{l}\text { PAHs; PBDEs; PCBs; } \\
\text { pesticides }\end{array}$ & $\begin{array}{l}\text { A method for the fast isolation of HOCs from exposed SPMDs using hexane as an extraction solvent was tested } \\
\text { for samplers deployed in various aquatic ecosystems. }\end{array}$ & [274] \\
\hline Calibration tank & $\begin{array}{l}\text { PAHs; PCBs; } \\
\text { pesticides }\end{array}$ & $\begin{array}{l}\text { Calculation of new, and recalculation of reported, polymer water partition coefficients for SPMD and SR, } \\
\text { through cosolvent, lipid and aqueous exposures in batch experiments, to facilitate conversion of equivalent } \\
\text { analyte concentrations between phases with only partition coefficients. }\end{array}$ & [11] \\
\hline \multicolumn{4}{|c|}{ Monitoring alongside biota } \\
\hline Coastal waters & $\begin{array}{l}\text { Dioxins; EDCs; } \\
\text { PAHs; PCBs } \\
\text { pesticides }\end{array}$ & $\begin{array}{l}\text { Monitoring with SPMD and biota (mussels, oysters, Atlantic cod) for a range of HOCs in coastal waters with a } \\
\text { range of climates and varying uses (e.g. shipyards, marinas, harbors, estuaries, estuarine lagoons), including } \\
\text { concurrent sediment monitoring. }\end{array}$ & {$[275-280]$} \\
\hline Coastal waters & $\begin{array}{l}\text { PAHs; PCBs; } \\
\text { pesticides }\end{array}$ & $\begin{array}{l}\text { Nine studies published in the decade prior to } 2006 \text { where mussels and SPMDs used to monitor HOCs were } \\
\text { evaluated, to investigate differences and similarities between the sampling methods including development of a } \\
\text { model to compare concentration ratios and comments on method reliability. }\end{array}$ & [92] \\
\hline Marine waters & PAHs; pesticides & $\begin{array}{l}\text { PSDs including SPMDs, POCIS, and DGT deployed alongside biota (mussels and fish) to monitor a range of } \\
\text { HOCs that may bioaccumulate in seafood flesh. }\end{array}$ & {$[287,288]$} \\
\hline
\end{tabular}


Table 3

Applications of the silicone rubber passive sampling device

\begin{tabular}{|c|c|c|c|}
\hline Environment & Analytes & Description & Ref \\
\hline \multicolumn{4}{|c|}{ Monitoring of discharges and dispersal of pollutants } \\
\hline Wastewater & PCBs & $\begin{array}{l}\text { SR deployed at outfalls and at downstream locations in receiving waters, including alongside other PSDs } \\
\text { (LDPE) to monitor the occurrence, concentration and fate of a range of HOCs found in treated wastewater } \\
\text { through targeted and qualitative chemical analysis. }\end{array}$ & {$[148,153]$} \\
\hline Calibration tank & PAHs; PCBs & $\begin{array}{l}\mathrm{SR} \text { and naked Empore }{ }^{\mathrm{TM}} \mathrm{C}_{18} \text { disks were deployed to monitor simulated discharges from the offshore oil and gas } \\
\text { industry during three exposures of fourteen days, each corresponding to one of three discharge scenarios } \\
\text { (continuous, discontinuous and short abrupt). }\end{array}$ & [143] \\
\hline Coastal waters & Dioxins & $\begin{array}{l}\text { Active sampling and SR and POM PSDs were deployed in pore water and the overlying water column at sites in } \\
\text { Frierfjord (Norway) to determine the freely dissolved equilibrium concentration of dioxins originating from a } \\
\text { historic } \mathrm{Mg} \text { smelter. }\end{array}$ & {$[114]$} \\
\hline \multicolumn{4}{|c|}{ Chemical speciation, distribution and degradation } \\
\hline Coastal waters & PAHs; PCBs & $\begin{array}{l}\text { SR deployed in the water column at a number of points along the Belgium coast to monitor the freely dissolved } \\
\text { concentration of a range of HOCs. Equilibrium models used to predict concentrations in sediment, suspended } \\
\text { particulate matter and biotic phases. }\end{array}$ & [175] \\
\hline Coastal waters & $\begin{array}{l}\text { PAHs; PCBs; } \\
\text { pesticides; synthetic } \\
\text { musk's; triclosan }\end{array}$ & $\begin{array}{l}\text { SR exposed alongside resident clams and caged mussels in mangroves (Singapore) and were measured } \\
\text { alongside sediments to determine the distribution of HOCs between environmental compartments. }\end{array}$ & [176] \\
\hline \multicolumn{4}{|c|}{ Monitoring spatial and temporal trends } \\
\hline River waters & $\begin{array}{l}\text { PAHs; PCBs; } \\
\text { pesticides; phthalates }\end{array}$ & $\begin{array}{l}\text { SR alongside Speedisk PSDs were used to monitor the spatial and temporal variation in sources, occurrence, } \\
\text { concentrations and fate of a range of HOCs within various river catchments. }\end{array}$ & {$[191-195,207]$} \\
\hline Coastal waters & $\begin{array}{l}\text { PAHs; PCBs; } \\
\text { pesticides }\end{array}$ & $\begin{array}{l}\text { SR and other PSDs (LDPE, Chemcatcher }{ }^{\mathbb{B}} \text { and SPMD) were deployed in various exposures at coastal sites to } \\
\text { investigate temporal and spatial trends in the concentration of a range of target HOCs and to screen for the } \\
\text { occurrence of HOCs and use of detection frequency to inform a fugacity model. }\end{array}$ & {$[61,237,289]$} \\
\hline Various (global) & Various & $\begin{array}{l}\text { Proposals for the global aquatic passive sampling network (AQUA-GAPS) employing SR and LDPE PSDs to } \\
\text { monitor HOCs at strategically important locations. }\end{array}$ & {$[211]$} \\
\hline \multicolumn{4}{|c|}{ Toxicity and toxicological monitoring } \\
\hline River waters & $\begin{array}{l}\text { EDCs; PAHs; PCBs; } \\
\text { pesticides }\end{array}$ & $\begin{array}{l}\text { SR and other PSDs (LDPE, POCIS-pharms, POCIS-pest) and biota (mussels), deployed in various rivers and } \\
\text { sampler extracts used in chemical and toxicological analyses and bioassays, including in EDA using HPLC } \\
\text { fractionalization coupled to bioassays as a way of profiling anti-androgenic activity. }\end{array}$ & {$[216,290-295]$} \\
\hline Coastal waters & $\begin{array}{l}\text { PAHs; PCBs; } \\
\text { pesticides }\end{array}$ & $\begin{array}{l}\text { SR including alongside POCIS deployed in field exposures and sampler extracts and grab samples underwent } \\
\text { chemical and toxicological analysis to assess water quality, including in EDA using HPLC fractionalization } \\
\text { coupled to LC-ToF-MS and bioassays (photosystem II activity, microalgae). }\end{array}$ & $\begin{array}{l}{[74,290,296-} \\
298]\end{array}$ \\
\hline Marine waters & Toxicological only & $\begin{array}{l}\text { SR used to sample marine waters and then passively dose an ecotoxicological test medium as part of the } \\
\text { development of an approach to aquatic toxicity monitoring. }\end{array}$ & {$[56]$} \\
\hline $\begin{array}{l}\text { Produced water } \\
\text { (oil and gas) }\end{array}$ & PAHs & $\begin{array}{l}\text { LDPE and SR exposed to a sample of produced water to determine the concentration of HOCs, with subsequent } \\
\text { use of sampler extracts and diluted produced water samples in zebrafish bioassays. }\end{array}$ & [299] \\
\hline \multicolumn{4}{|c|}{ Calibration and sampler performance } \\
\hline River waters & $\begin{array}{l}\text { HCBD; PAHs; } \\
\text { PBDEs; PCBs; } \\
\text { pesticides }\end{array}$ & $\begin{array}{l}\text { SR alone and alongside other PSDs (SPMDs, LDPE and POM) underwent various exposures in rivers to } \\
\text { monitor a range of HOCs to evaluate the effect of PSD selection, design and deployment strategy on } \\
\text { performance. To determine the influence of SPM on the surface of SR PSDs on the reliability of } \text { in-situ }\end{array}$ & $\begin{array}{l}{[12,26,47,89,} \\
227,300]\end{array}$ \\
\hline
\end{tabular}




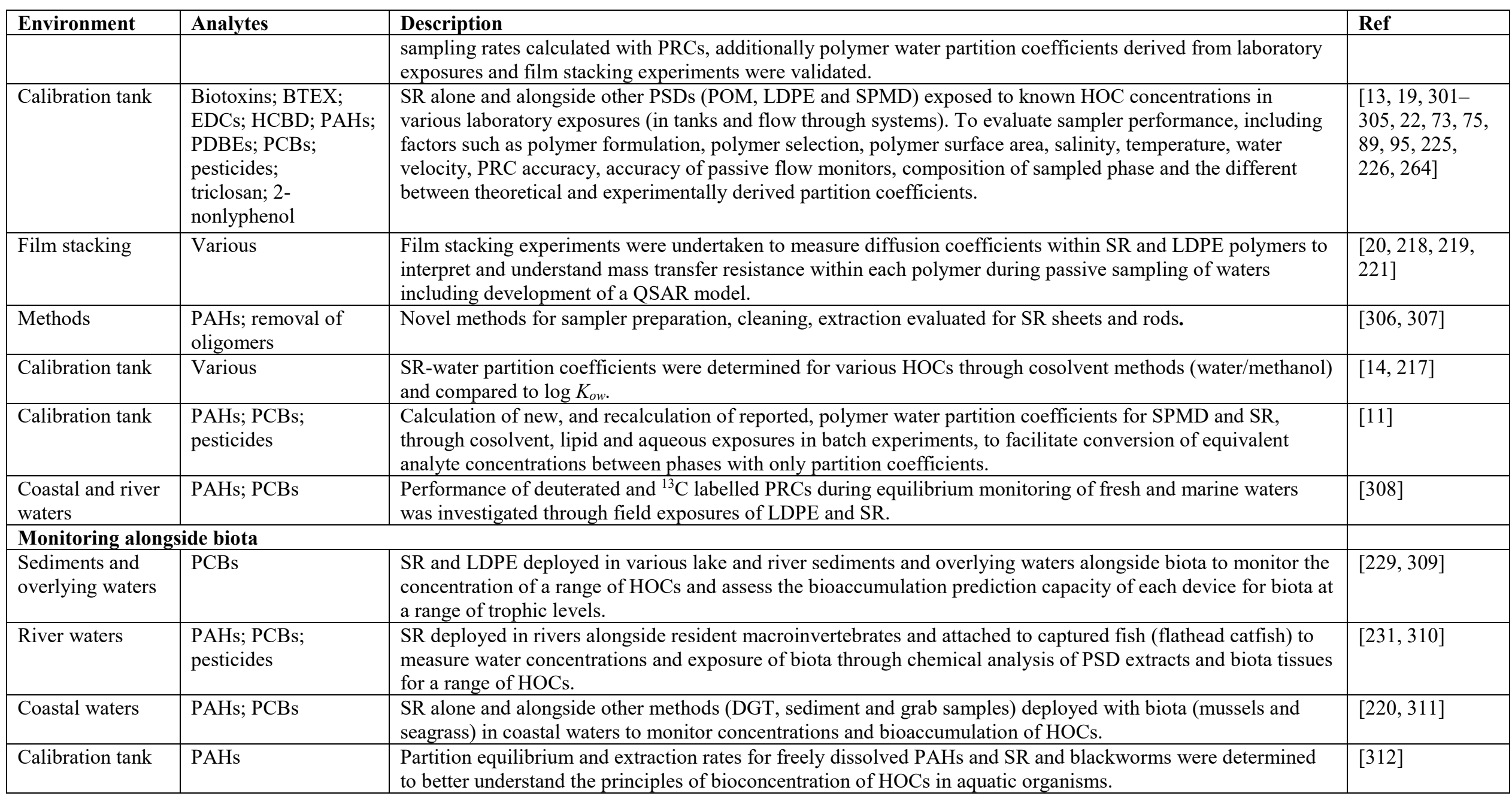


Table 4

Applications of the low-density polyethylene passive sampling device

\begin{tabular}{|c|c|c|c|}
\hline Environment & Analytes & Description & Ref \\
\hline \multicolumn{4}{|c|}{ Monitoring of process efficacy } \\
\hline Calibration tank & $\begin{array}{l}\text { Limonene; pesticides; } \\
\text { pinene }\end{array}$ & $\begin{array}{l}\text { LDPE calibrated for HOCs and exposed in three phase systems (LDPE, water and sorbent), to infer analyte } \\
\text { uptake to several carbonaceous geosorbents and virgin and regenerated activated carbon. }\end{array}$ & {$[116,117]$} \\
\hline \multicolumn{4}{|c|}{ Monitoring of discharges and dispersal of pollutants } \\
\hline Wastewater & PCBs; PFASs & $\begin{array}{l}\text { LDPE deployed at outfalls and at upstream and downstream locations in receiving waters (rivers), including } \\
\text { alongside other PSDs (SR) and in the overlying atmosphere to monitor the occurrence, concentration and fate } \\
\text { of HOCs found in treated wastewater. }\end{array}$ & {$[146-148]$} \\
\hline Lake waters & PAHs & $\begin{array}{l}\text { LDPE deployed in water and the overlying atmosphere at locations around the lower Great Lakes (USA) to } \\
\text { monitor the freely dissolved and gaseous concentration of PAH and determine the influence of proximity to } \\
\text { sources (population centers and wastewater treatment works effluent) and impact of vectors (river discharges } \\
\text { and precipitation) on measured concentrations. }\end{array}$ & {$[313]$} \\
\hline Antarctic lakes & PAHs & LDPE deployed in seven lakes in Antarctica to track human footprints through PAH concentrations. & {$[155]$} \\
\hline \multicolumn{4}{|c|}{ Chemical speciation, distribution and degradation } \\
\hline River waters & PBDEs; PCBs & $\begin{array}{l}\text { LDPE deployed in various environmental compartments including air, water sediment, and pore water, to } \\
\text { study the partitioning and mass fluxes of various HOCs between compartments. }\end{array}$ & {$[181,182]$} \\
\hline Marine waters & $\begin{array}{l}\text { PAHs; PBDEs; PCBs; } \\
\text { pesticides }\end{array}$ & $\begin{array}{l}\text { LDPE, POM and SPME deployed along depth gradients and in sediments and overlying waters to investigate } \\
\text { the vertical distribution and mass flux between environment compartments of HOCs. }\end{array}$ & $\begin{array}{l}{[167,168,} \\
185]\end{array}$ \\
\hline Lake waters & $\begin{array}{l}\text { FRs; PBDEs; PCBs; } \\
\text { pesticides }\end{array}$ & $\begin{array}{l}\text { LDPE deployed in water and the overlying atmosphere at sites in the Great Lakes (USA and Canada), to } \\
\text { determine the spatial variation in concentration, partitioning and mass fluxes of a range of HOCs between the } \\
\text { air and water compartments. }\end{array}$ & {$[178-180]$} \\
\hline Coastal waters & Dioxins & $\begin{array}{l}\text { LDPE deployed at five sites in the water column and overlying atmosphere in Newark Bay (USA) to monitor } \\
\text { concentrations of dioxins and mass fluxes between air and aqueous phases. }\end{array}$ & {$[183]$} \\
\hline Coastal waters & $\begin{array}{l}\text { FRs; PAHs; PBDEs; } \\
\text { pesticides; PPCPs }\end{array}$ & $\begin{array}{l}\text { A variety of methods were used to investigate the vertical distribution of a range of HOCs in coastal waters, } \\
\text { including grab samples and LDPE deployed along depth gradients and in sediments. }\end{array}$ & {$[169,170]$} \\
\hline Marine waters & PBDEs & $\begin{array}{l}\text { LDPE passive and active sampling devices were deployed on an east west transect of the tropical Atlantic } \\
\text { Ocean in the water column and overlying atmosphere to monitor the spatial distribution in concentration and } \\
\text { mass fluxes between air and aqueous phases. }\end{array}$ & {$[184]$} \\
\hline \multicolumn{4}{|c|}{ Monitoring spatial and temporal trends } \\
\hline River waters & $\begin{array}{l}\text { PAHs; PBDEs; PCBs } \\
\text { pesticides }\end{array}$ & $\begin{array}{l}\text { LDPE deployed, including alongside other methods (SPMD, POCIS and High volume grab sampling), to } \\
\text { measure spatial and temporal trends in HOC sources, occurrence and concentration. }\end{array}$ & {$[196-199]$} \\
\hline Wetland waters & Pesticides & $\begin{array}{l}\text { LDPE deployed in surface waters and the overlying atmosphere to determine the altitudinal variation in the } \\
\text { concentration of organochlorine pesticides in mountain ranges in southern Brazil. }\end{array}$ & {$[209]$} \\
\hline $\begin{array}{l}\text { Marine, costal } \\
\text { and lake waters }\end{array}$ & OPEs & $\begin{array}{l}\text { LDPE deployed on deep water moorings at a number of locations in the Fram Strait (Canada) and in several } \\
\text { surface water sites in lakes and coastal waters of the Canadian Arctic to monitor concentrations of a range of } \\
\text { organophosphate esters (OPEs). }\end{array}$ & {$[314]$} \\
\hline Various (global) & Various & $\begin{array}{l}\text { Proposals for the global aquatic passive sampling network (AQUA-GAPS) employing SR and LDPE PSDs to } \\
\text { monitor HOCs at strategically important locations. }\end{array}$ & {$[72,211]$} \\
\hline
\end{tabular}




\begin{tabular}{|c|c|c|c|}
\hline Environment & Analytes & Description & Ref \\
\hline Coastal waters & $\begin{array}{l}\text { PAHs; pesticides; } \\
\text { phthalates; synthetic } \\
\text { musk's }\end{array}$ & $\begin{array}{l}\text { LDPE exposed in several coastal waters and sampler extracts (without and after iterative fractionalization) } \\
\text { were used in several bioassays and analyzed chemically, to determine and attribute associated toxicity for a } \\
\text { range of HOCs. }\end{array}$ & {$[52,315]$} \\
\hline River waters & EDCs; PAHs & $\begin{array}{l}\text { LDPE, SR and POCIS exposed in a number of rivers and sampler extracts were chemically analyzed and used } \\
\text { in a range of bioassays including in effect driven analysis (HPLC fractionalization coupled to bioassays) to } \\
\text { profile toxicity in sampled waters. }\end{array}$ & {$[291,316]$} \\
\hline $\begin{array}{l}\text { Produced water } \\
\text { (oil and gas) }\end{array}$ & PAHs & $\begin{array}{l}\text { LDPE and SR exposed to produced water to determine the HOC concentrations and subsequent use of } \\
\text { sampler extracts and diluted produced water samples in several zebrafish bioassays. }\end{array}$ & {$[299]$} \\
\hline \multicolumn{4}{|c|}{ Calibration and sampler performance } \\
\hline $\begin{array}{l}\text { Coastal, lake and } \\
\text { river waters }\end{array}$ & $\begin{array}{l}\text { PAHs; PCBs; } \\
\text { pesticides }\end{array}$ & $\begin{array}{l}\text { The performance of LDPE alone and alongside other PSDs (SR, SPMD and SPME), and influence of factors } \\
\text { such as use of deuterated and }{ }^{13} \mathrm{C} \text { labelled PRCs, PSD design and deployment methodology, and PRC } \\
\text { correction, was tested in a range of field exposures. }\end{array}$ & $\begin{array}{l}{[300,317-} \\
321]\end{array}$ \\
\hline Modelled data & Various & $\begin{array}{l}\text { Two mechanistic models to predict partition coefficients for HOCs between LDPE and aqueous phases } \\
\text { developed using data available in the extant literature. }\end{array}$ & {$[30]$} \\
\hline Calibration tank & $\begin{array}{l}\text { PAHS; PBDEs; PCBs; } \\
\text { pesticides }\end{array}$ & $\begin{array}{l}\text { Model to account for non-equilibrium exposure conditions developed based on HOC, uptake rate constants, } \\
\text { elimination rate constants and water polymer partition coefficients in batch experiments. }\end{array}$ & {$[322]$} \\
\hline Modelled data & PAHs; PCBs & A QSAR model was developed to predict the diffusion coefficient for various HOCs in LDPE PSDs. & [323] \\
\hline $\begin{array}{l}\text { Calibration tank } \\
\text { and field } \\
\text { exposures }\end{array}$ & $\begin{array}{l}\text { Dioxins; PAHs; } \\
\text { PBDEs; PCBs; } \\
\text { pesticides }\end{array}$ & $\begin{array}{l}\text { The performance of a range of PSDs (LDPE, SR, PU, PMMA, POM and SPMDs) to monitor HOCs based on } \\
\text { polymer selection and thickness. Tested in laboratory experiments and selected PSDs were then tested in field } \\
\text { exposures, including the development of predictive models. }\end{array}$ & $\begin{array}{l}{[65,76,89,} \\
324,325]\end{array}$ \\
\hline Film stacking & PAHs; PBDEs; PCBs & Film stacking experiments measuring resistance to mass transfer $\left(D_{p}\right)$ in SR and LDPE. & {$[20,219]$} \\
\hline Wastewaters & cVMS & In-situ calibration of LDPE spiked with PRCs, for cVMS, during exposure in wastewater effluent. & {$[326]$} \\
\hline Calibration tank & $\begin{array}{l}\text { Biotoxins; PAHs; } \\
\text { PCBs; pesticides; }\end{array}$ & $\begin{array}{l}\text { LDPE alone and alongside other PSDs (SR and HDPE) were exposed to known HOC concentrations in } \\
\text { laboratory exposures (in tanks and flow through systems) to evaluate sampler performance, and the influence } \\
\text { of factors such as flow velocity, polymer selection and thickness, PRC accuracy, temperature and salinity, } \\
\text { including the development of a predictive model. }\end{array}$ & $\begin{array}{l}{[75,77,226} \\
303,305,327 \\
329]\end{array}$ \\
\hline \multicolumn{4}{|c|}{ Monitoring alongside biota } \\
\hline Coastal waters & $\begin{array}{l}\text { Dioxins; FRs; PAHs; } \\
\text { PBDEs; PCBs; } \\
\text { pesticides }\end{array}$ & $\begin{array}{l}\text { LDPE including alongside PSDs (POCIS, SPME and DGT) and biota (gulf killifish, mussels and shellfish) } \\
\text { deployed in coastal waters to evaluate the application of each method to monitor HOCs and predict } \\
\text { concentrations in biota. }\end{array}$ & {$[330-334]$} \\
\hline $\begin{array}{l}\text { River and lake } \\
\text { waters }\end{array}$ & PAHs; PCBs & $\begin{array}{l}\text { LDPE alone and alongside SR co-deployed with biota in a range of surface waters and sediments to monitor } \\
\text { concentrations of a range of HOCs and access the bioaccumulation prediction capacity of each device for } \\
\text { sampled biota at various trophic levels. }\end{array}$ & $\begin{array}{l}{[229,309,} \\
335]\end{array}$ \\
\hline
\end{tabular}


Table 5

Applications of the Chemcatcher ${ }^{\circledR}$ passive sampling device

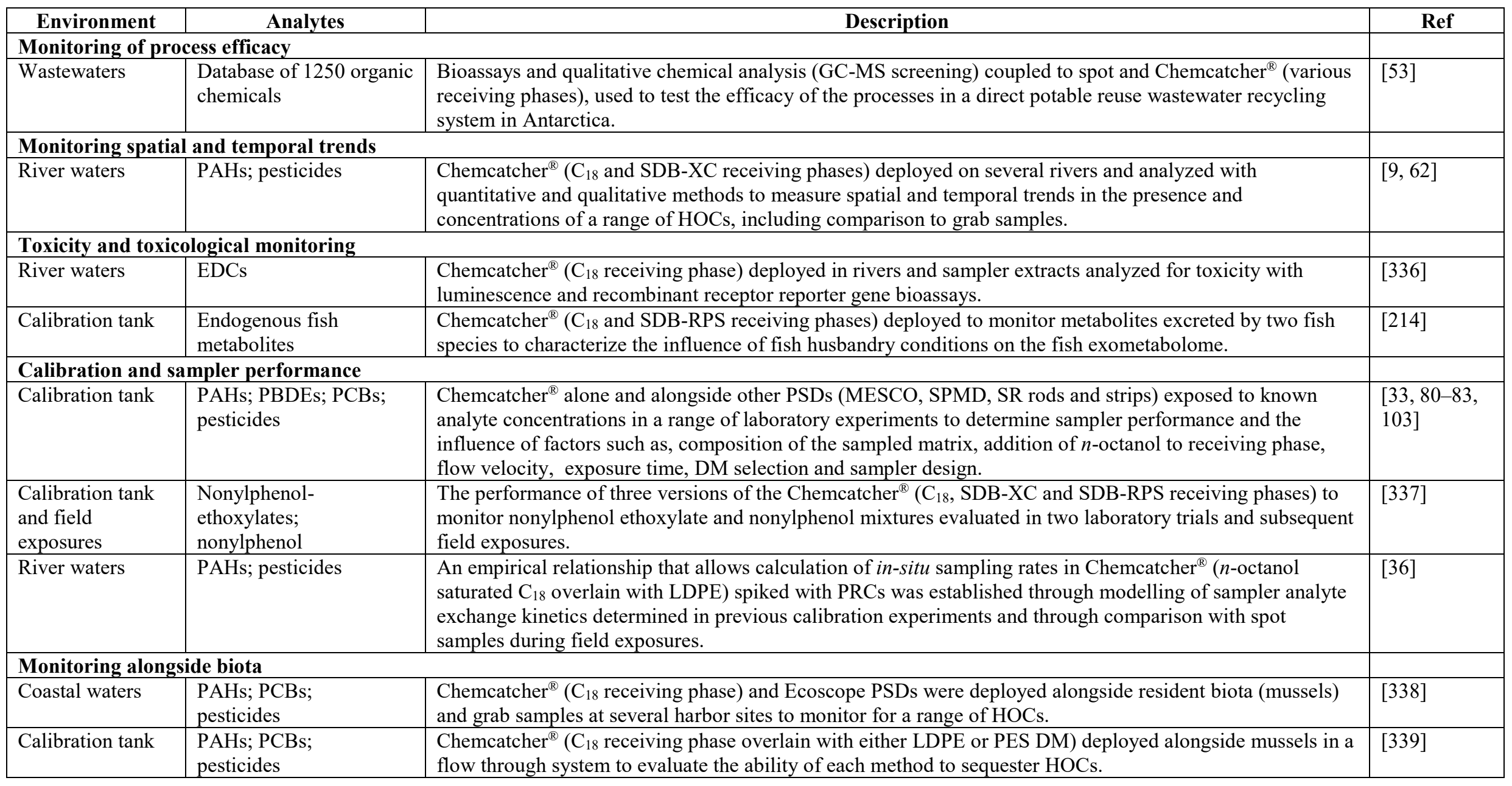


Table 6

Applications of the solid-phase microextraction passive sampling device

\begin{tabular}{|c|c|c|c|}
\hline Environment & Analytes & Description & Ref \\
\hline \multicolumn{4}{|c|}{ Monitoring of process efficacy } \\
\hline $\begin{array}{l}\text { Contaminated } \\
\text { sediments }\end{array}$ & PAHs; PCBs & $\begin{array}{l}\text { Two sediment remediation strategies (capping and addition of activated carbon) assessed through measurement } \\
\text { of HOCs in sediments and overlying waters (with PDMS-SPME) and resident biota. }\end{array}$ & [118] \\
\hline \multicolumn{4}{|c|}{ Chemical speciation, distribution and degradation } \\
\hline Marine waters & PCBs & $\begin{array}{l}\text { Ex-situ analysis of PCB concentrations in sediments and bottom waters with PDMS-SPME to assess spatial } \\
\text { variation in diffusion gradients at the sediment water interface, site specific mixture compositions and baseline } \\
\text { toxicity potentials. }\end{array}$ & [340] \\
\hline Marine waters & PCBs; pesticides & LDPE and SPME deployed along depth gradients to investigate vertical distribution of HOCs. & [168] \\
\hline Marine waters & PCBs; pesticides & SPME, LDPE and POM deployed in sediment and overlying water to measure HOC mass flux. & {$[185]$} \\
\hline \multicolumn{4}{|c|}{ Toxicity and toxicological monitoring } \\
\hline Calibration tank & $\begin{array}{l}\text { Hydrocarbons } \\
\text { (various) }\end{array}$ & $\begin{array}{l}\text { The use of PDMS-SPME fibers as a biomimetic extraction procedure to access bioavailability and predict } \\
\text { toxicity of petroleum substances, was tested in a simulated spill and laboratory exposures. }\end{array}$ & {$[212,213]$} \\
\hline \multicolumn{4}{|c|}{ Calibration and sampler performance } \\
\hline Calibration tank & $\begin{array}{l}\text { PAHs; PCBs; } \\
\text { pesticides }\end{array}$ & $\begin{array}{l}\text { PDMS-SPME fibers exposed to known HOCs in laboratory exposures to access sampler performance, including } \\
\text { the influence of factors such as, DOM, water velocity, temperature, and to create predictive models, develop } \\
\text { new methods for the use of PRCs, new sampler designs and to determine the } K_{O W} \text { for several HOCs. }\end{array}$ & $\begin{array}{l}{[31,84} \\
341-343]\end{array}$ \\
\hline $\begin{array}{l}\text { Calibration tank } \\
\text { and river waters }\end{array}$ & PPCPs & $\begin{array}{l}\mathrm{C}_{18} \text { (thin film) SPME PSDs used in lab and field exposures to evaluate the ability to measure TWA } \\
\text { concentrations wastewater associated HOCs, alongside HLB SPME PSDs for polar compounds. }\end{array}$ & [344] \\
\hline $\begin{array}{l}\text { Marine, coastal } \\
\text { and lake waters }\end{array}$ & $\begin{array}{l}\text { EDCs; PAHs; PCBs; } \\
\text { pesticides }\end{array}$ & $\begin{array}{l}\text { The performance of a range of SPME fibers coatings (acrylate, nylon and SR) and SPME PSD designs to } \\
\text { monitor a range of HOCs assessed through field exposures, including comparison to other methods such as } \\
\text { LDPE, SPMD and POM, grab samples and biota monitoring. }\end{array}$ & $\begin{array}{l}{[85,112} \\
308,320 \\
345]\end{array}$ \\
\hline \multicolumn{4}{|c|}{ Monitoring alongside biota } \\
\hline Coastal waters & $\begin{array}{l}\text { FRs; PAHs; PBDEs; } \\
\text { PCBs; } \\
\text { pesticides }\end{array}$ & $\begin{array}{l}\text { SPME fibers, POCIS and LDPE were deployed at coastal sites to monitor the concentration and relative } \\
\text { abundance of a range of HOCs and compared to concentrations in mussel tissues. }\end{array}$ & {$[331]$} \\
\hline
\end{tabular}


Table 7

Applications of other polymeric passive sampling devices

\begin{tabular}{|c|c|c|c|}
\hline Environment & Analytes & Description & Ref \\
\hline \multicolumn{4}{|c|}{ Monitoring of process efficacy } \\
\hline Calibration tank & PAHs; pesticides & $\begin{array}{l}\text { Performance of POM and PU determined in batch experiments followed by laboratory scale exposures to test } \\
\text { efficacy of a biochar treatment method (contaminated sediments) and bioretention cell (storm water treatment } \\
\text { system). }\end{array}$ & {$[119,121]$} \\
\hline River waters & PCBs & $\begin{array}{l}\text { POM deployed in sediment and the overlying water column at river sites to monitor the bioavailable fraction } \\
\text { and mass fluxes of PCBS during sediment remediation with activated carbon. }\end{array}$ & {$[120]$} \\
\hline \multicolumn{4}{|c|}{ Monitoring of discharges and dispersal of pollutants } \\
\hline $\begin{array}{l}\text { Calibration tank } \\
\text { and coastal } \\
\text { waters }\end{array}$ & $\begin{array}{l}\text { Dioxins; PAHs; } \\
\text { PCBs; pesticides }\end{array}$ & $\begin{array}{l}\text { PSDs made from EVA, SR and POM polymers used to monitor the dispersal of HOCs associated with } \\
\text { pisciculture (after laboratory calibration), a historic Mg smelter (compared with active sampling) and } \\
\text { sediment dredging and relocation. }\end{array}$ & $\begin{array}{l}{[114,159,} \\
346]\end{array}$ \\
\hline Wastewaters & Various & $\begin{array}{l}\text { A novel mixed polymer PSD (PDMS and HLB) and POCIS deployed in effluent and receiving waters to } \\
\text { monitor the discharge and dispersal of } 44 \text { organic compounds with a broad hydrophobicity. }\end{array}$ & {$[154]$} \\
\hline \multicolumn{4}{|c|}{ Chemical speciation, distribution and degradation } \\
\hline Marine waters & Dioxins; PCBs & $\begin{array}{l}\text { POM deployed in the water column and high-volume air samplers in the overlying atmosphere at marine sites } \\
\text { to determine the aerosol water distribution of PCBs and dioxins. }\end{array}$ & {$[177]$} \\
\hline Marine waters & PCBs; pesticides & POM, LDPE and SPME deployed in sediment and overlying water to measure HOC mass flux. & {$[185]$} \\
\hline \multicolumn{4}{|c|}{ Monitoring spatial and temporal trends } \\
\hline Marine waters & Dioxins; PCBs & $\begin{array}{l}\text { POM were deployed at two depths ( } 5 \mathrm{~m} \text { above the seafloor and } 25 \mathrm{~m} \text { below the surface) at five sites in the } \\
\text { Baltic Sea to investigate the spatial distribution in the concentration of dioxins and PCBs. }\end{array}$ & [347] \\
\hline Coastal waters & $\begin{array}{l}\text { Dioxins; PCBs; } \\
\text { pesticides }\end{array}$ & $\begin{array}{l}\text { POM and EVA deployed in a range of coastal waters, including alongside PSDs deployed in the overlying } \\
\text { atmosphere to monitor seasonal and spatial trends in various HOCs. }\end{array}$ & {$[348-350]$} \\
\hline \multicolumn{4}{|c|}{ Calibration and sampler performance } \\
\hline $\begin{array}{l}\text { Calibration tank } \\
\text { and field } \\
\text { exposures }\end{array}$ & Various & $\begin{array}{l}\text { The performance of a range of PSDs (a novel form of POCIS containing a sorbent mixture and nylon } \\
\text { membrane, a PES hollow fiber, LDPE, PU, PMMA, POM and SR), in laboratory experiments followed by } \\
\text { field exposures to a broad range of HOCs in coastal, river and wastewaters. }\end{array}$ & $\begin{array}{l}{[89,324} \\
351,352]\end{array}$ \\
\hline Calibration tank & Various & $\begin{array}{l}\text { The performance of a range of PSDs (silicone matrix containing HLB beads, POCIS, PDMS, POM, PDMS } \\
\text { stir bars, MESCO and PES tubes) were evaluated in laboratory exposures to organic chemicals over a broad } \\
\text { hydrophobicity. }\end{array}$ & $\begin{array}{l}{[15,28,87,} \\
302,353]\end{array}$ \\
\hline
\end{tabular}


Table 8

Comparison of different passive sampling devices

\begin{tabular}{|c|c|c|c|}
\hline Environment & Analytes & Description & Ref \\
\hline \multicolumn{4}{|c|}{ Reviews of passive sampling for HOCs in aquatic matrices } \\
\hline- & - & Reviews on the development and state of the art of a range of PSDs. & $\begin{array}{l}{[67,94,354,} \\
355]\end{array}$ \\
\hline- & - & $\begin{array}{l}\text { Review of active and passive sampling (POCIS, SMPDs, LDPE, POM and SR) and analytical consideration and } \\
\text { coupled methods such as bioassays. }\end{array}$ & {$[356]$} \\
\hline- & - & $\begin{array}{l}\text { Reviews on advances in analysis of pharmaceuticals in aquatic environments including SPMD, Chemcatcher }{ }^{(B)} \\
\text { and SPME PSDs for HOCs. }\end{array}$ & [357] \\
\hline- & - & $\begin{array}{l}\text { Reviews of methods to access the bioavailability of HOCs in a range of environmental matrices including LDPE, } \\
\text { SR, POM, SPMD and SPME. }\end{array}$ & {$[88,230]$} \\
\hline- & - & $\begin{array}{l}\text { Review of dynamic accumulation processes for HOCs in PSDs }\left(\text { Chemcatcher }^{\mathbb{R}}, \text { SPMD, LDPE, SR-SPME) and }\right. \\
\text { trophically diverse biota. }\end{array}$ & [358] \\
\hline- & - & $\begin{array}{l}\text { Reviews of the use, shortcomings and strengths of passive sampling methods and presentation of the potential for } \\
\text { passive sampling in compliance and regulatory monitoring requirements (of HOCs) of the United States, EU and } \\
\text { Oslo-Paris Convention for the protection of the marine environment of the North East Atlantic, including scrutiny } \\
\text { on the applicability, and uncertainties of the information produced from passive samplers, within this context. }\end{array}$ & {$[4,10,359-361]$} \\
\hline- & - & Review of the use of SR in analytical chemistry including uses in SR PSDs, and PDMS SPME and stir bar PSDs. & {$[98,360,362]$} \\
\hline- & - & $\begin{array}{l}\text { A review of polyethylene water equilibrium partitioning constants for HOCs in the extant literature and the } \\
\text { implications for the use of polyethylene receiving phases in passive sampling. }\end{array}$ & [101] \\
\hline- & - & $\begin{array}{l}\text { Reviews of the principles, calibration, preparation, field applications and analysis of various chemicals with the } \\
\text { Chemcatcher }{ }^{\mathbb{B}} \text {. }\end{array}$ & {$[363-365]$} \\
\hline- & - & $\begin{array}{l}\text { Position papers on the current state of the art for environmental monitoring with PSDs in aquatic matrices and } \\
\text { future challenges. }\end{array}$ & {$[32,366]$} \\
\hline- & - & Review of current calibration methods in passive sampling, including HOCs in aquatic matrices. & {$[21]$} \\
\hline- & - & Reviews of SPME for on-site sampling, in analysis of water samples and geometries and coatings. & {$[105-110]$} \\
\hline \multicolumn{4}{|c|}{ Comparison of different passive samplers } \\
\hline Stormwater & PAHs & $\begin{array}{l}\text { SPMDs and LDPE PSDs (of varying surface area) and grab sampling used to monitor the occurrence and } \\
\text { concentration of HOCs in stormwater. }\end{array}$ & [367] \\
\hline $\begin{array}{l}\text { Modelled data } \\
\text { and GCxGC }\end{array}$ & Various & $\begin{array}{l}\text { A model to predict partitioning behavior and diffusion coefficients of HOCs in biota and PSDs (POM, LDPE, } \\
\text { PA, PU, PDMS and SPMD) developed and validate based on GCxGC retention times and data from the extant } \\
\text { literature. }\end{array}$ & {$[29]$} \\
\hline Modelled data & Various & $\begin{array}{l}\text { Novel statistical interpretation of the error structure of PRC data to enable an improved method for estimating in- } \\
\text { situ sampling rates of HOCs during passive sampling with various devices (including SPMDs, LDPE, SR and } \\
\text { Chemcatcher }{ }^{\mathbb{B}} \text { ). }\end{array}$ & {$[18]$} \\
\hline $\begin{array}{l}\text { Ground water } \\
\text { (managed aquafer } \\
\text { recharge) }\end{array}$ & $\begin{array}{l}\text { Pesticides; } \\
\text { synthetic musk's }\end{array}$ & $\begin{array}{l}\text { Monitoring of HOCs in an urban storm water recycling system, using SPMD, XAD resin, SR and Chemcatcher }{ }^{(B)} \\
\text { PSDs alongside passive flow monitors deployed at sample wells located at varying distances from the recharge } \\
\text { well. }\end{array}$ & {$[368]$} \\
\hline $\begin{array}{l}\text { River waters } \\
\text { (field exposures } \\
\text { and flow through } \\
\text { system) }\end{array}$ & $\begin{array}{l}\text { Alkylphenols; } \\
\text { PAHs; PBDEs; } \\
\text { PCBs; pesticides; } \\
\text { synthetic musk's }\end{array}$ & $\begin{array}{l}\text { Various exposures in river waters of multiple PSDs (SR sheets and rods, LDPE, SPMD, POM, PVC, PU, PC, } \\
\text { MESCO, Chemcatcher }{ }^{\circledR}, \text { POCIS and naked SDB-PRS Empore }{ }^{\mathrm{TM}} \text { disks), including alongside composite sampling } \\
\text { and autosamplers, and inside an exposure cell in a novel dynamic sampling device, to compare the application of } \\
\text { each method to monitor a range of HOCs. }\end{array}$ & $\begin{array}{l}{[33,54,63,69,} \\
300,369-373]\end{array}$ \\
\hline
\end{tabular}




\begin{tabular}{|c|c|c|c|}
\hline Environment & Analytes & Description & Ref \\
\hline Calibration tank & $\begin{array}{l}\text { PAHs; PCBs; } \\
\text { pesticides }\end{array}$ & $\begin{array}{l}\text { Exposure of a range of PSDs (SR, LDPE, SPMD, POM, PVC, PU, PC, POCIS-pharms, POCIS-pest and } \\
\text { Chemcatcher }{ }^{\circledR} \text { ) and active samplers (CFIS), to known analyte concentrations in laboratory exposures, to } \\
\text { investigate performance and the application of each device to monitor a range of HOCs. }\end{array}$ & $\begin{array}{l}{[33,371,374,} \\
375]\end{array}$ \\
\hline Coastal waters & $\begin{array}{l}\text { PAHs; PBDEs; } \\
\text { PCBs; triclosan }\end{array}$ & $\begin{array}{l}\text { Comparison of the application of a range of PSDs (SPMD, SR, SPME, LDPE, POM, POM-55 and POM-500) to } \\
\text { monitor HOCs in coastal waters. }\end{array}$ & $\begin{array}{l}{[23,79,308,} \\
319,376]\end{array}$ \\
\hline $\begin{array}{l}\text { Treated } \\
\text { wastewaters }\end{array}$ & Various & $\begin{array}{l}\text { LDPE, SR, Chemcatcher }{ }^{\circledR} \text { (fitted with both SDB/RPS and SDB/XC Empore }{ }^{\mathrm{TM}} \text { disks, overlain with a DM and } \\
\text { naked), SPMD and POCIS PSDs tested alongside composite sampling as part of an interlaboratory study } \\
\text { (NORMAN Network). Investigated a range of PSDs exposed in a parallel deployment at a single site to compare } \\
\text { and verify the analytical standards in participating laboratories and identify the current weak points of adsorption } \\
\text { based PSDs and suggest procedures for future method validation. }\end{array}$ & {$[64]$} \\
\hline Calibration tank & PAHs & $\begin{array}{l}\text { The application of thirteen polymers as single-phase passive samplers of HOCs investigated during batch } \\
\text { experiments measuring four critical properties namely, release of oligomers, swelling in solvents, diffusion } \\
\text { coefficients and partition coefficients. }\end{array}$ & {$[66]$} \\
\hline Modelled data & PAHs & $\begin{array}{l}\text { Contaminant uptake models for single phase PSDs (LDPE, POM and PDMS) informed by polymer and chemical } \\
\text { structure were developed and validated with data from the extant literature. }\end{array}$ & {$[222,223]$} \\
\hline $\begin{array}{l}\text { Calibration tank } \\
\text { and river waters }\end{array}$ & Pesticides & $\begin{array}{l}\text { The performance of five PSDs: pharms-POCIS, pest-POCIS, two versions of the Chemcatcher }{ }^{\mathbb{R}}\left(\mathrm{C}_{18} \text { and SDB- }\right. \\
\text { RPS receiving phases) and SR, to monitor mass fluxes of } 124 \text { legacy and current use pesticides, was evaluated } \\
\text { through laboratory calibration experiments (POCIS and Chemcatcher }{ }^{\mathbb{B}} \text { devices) and field exposures (all devices), } \text { including protocols for PSD preparation, calibration, extraction methods and instrumental analysis. } \\
\text { includis. }\end{array}$ & [377] \\
\hline $\begin{array}{l}\text { River and coastal } \\
\text { waters }\end{array}$ & PAHs; pesticides & $\begin{array}{l}\text { Interlaboratory study (24 laboratories) comparing various PSDs (DGT, POCIS, non polar, polar and metals } \\
\text { versions of the Chemcatcher }{ }^{\circledR}, \text { SR, LDPE, SPMD and MESCO) performance in surface waters. }\end{array}$ & {$[378]$} \\
\hline Calibration tank & $\begin{array}{l}\text { Dioxins; PCBs; } \\
\text { pesticides }\end{array}$ & $\begin{array}{l}\text { The application a range novel PSDs (either polymeric electrospun nanofiber mats formed of a number of } \\
\text { polymers (PAN, PMMA and PS) or composite SR polymers with embedded SPE sorbents) were evaluated in } \\
\text { laboratory sorption experiments in water spiked with chemicals of a broad hydrophobicity. }\end{array}$ & {$[115,379]$} \\
\hline
\end{tabular}

*Calibration tank encompasses all exposure systems ranging from artificial rivers to test tubes. **Coastal waters encompass near shore marine waters, harbors and transitional waters. 